\title{
SITE OBSERVATIONAL WORK PLAN FOR THE UMTRA PROJECT SITE AT FALLS CITY, TEXAS
}

\section{September 1994}

Prepared for

U.S. Department of Energy UMTRA Project Office

Albuquerque, New Mexico

Prepared by

Jacobs Engineering Group Inc.

Albuquerque, New Mexico

\section{0 \\ $4661<1130$

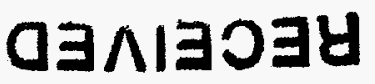




\section{DISCLAIMER}

This report was prepared as an account of work sponsored by an agency of the United States Government. Neither the United States Government nor any agency thereof, nor any of their employees, make any warranty, express or implied, or assumes any legal liability or responsibility for the accuracy, completeness, or usefulness of any information, apparatus, product, or process disclosed, or represents that its use would not infringe privately owned rights. Reference herein to any specific commercial product, process, or service by trade name, trademark, manufacturer, or otherwise does not necessarily constitute or imply its endorsement, recommendation, or favoring by the United States Government or any agency thereof. The views and opinions of authors expressed herein do not necessarily state or reflect those of the United States Government or any agency thereof. 


\section{DISCLAIMER}

Portions of this document may be illegible in electronic image products. Images are produced from the best available original document. 


\section{EXECUTIVE SUMMARY}

The requirements for ground water compliance for Uranium Mill Tailing Remedial Action (UMTRA) Project sites, including the Falls City site, are found in the Uranium Mill Tailings Radiation Control Act (42 USC $\$ 7901$ et seq.) and Subparts A, B, and C of the Environmental Protection Agency's Health and Environmental Protection Standards for Uranium and Thorium Mill Tailings. These standards are codified in 40 CFR Part 192 (1994), and the proposed 1987 standards published in 52 FR 36000 (1987). Subpart C of 40 CFR Part 192 (1994) describes the conditions under which the U.S. Department of Energy may apply supplemental standards to contaminated ground water rather than meeting background levels or numerical standards.

Ground water beneath the Falls City site was contaminated by uranium ore processing activities and open pit mining. Open pit mining occurred at the Falls City site before the milling activities. The mines were on parcels $A$ and $B$ of the site.

A total of 2.5 million tons (2.3 million tonnes) of uranium ore were extracted and processed on the site. An acid-leach, countercurrent-decantation solvent extraction system was used to extract and concentrate uranium. The Deweesville sandstone containing the uranium was mined, ground, and then soaked in a sulfuric acid solution. An organic solution was added during the extraction circuit. The uranium was stripped from the organic solution with either a sodium carbonate or an acidified sodium chloride solution. The residue sands, sandy-slimes, and slimes from processing uranium ore (tailings) were left on the mill site.

During surface remedial action, an estimated 7.0 million tons (6.4 million tonnes) of uranium mill tailings and other contaminated materials were consolidated and stabilized on the site. The ground water protection strategy at the Falls City disposal site for the UMTRA Surface Project (Subpart A of 40 CFR Part 192 (1994)) was an application for supplemental standards, based on Class III (limited use) ground water in the uppermost aquifer. This water is not a current or potential source of drinking water. Ground water from the uppermost aquifer (ground water from the Deweesvilie/Conquista Members and the Dilworth Member) contains widespread ambient contamination resulting from naturally occurring conditions and from the effects of human activity not related to uranium milling operations (uranium exploration and mining activities). The ground water cannot be effectively cleaned up for drinking or other beneficial purposes using treatment methods reasonably employed by public water supply systems. The U.S. Nuclear Regulatory Commission (NRC) and the state of Texas concurred with the ground water protection strategy for the disposal site in September 1992. Surface remedial action in accord with Subpart A was completed in April 1994.

The proposed ground water compliance strategy (Subpart B of 40 CFR Part 192 (1994)) at the Falls City site is to perform no remedial action based on application for supplemental standards because the ground water in the uppermost aquifer is classified as Class III ground water. Class III ground water includes ground water that is not a current or potential source of drinking water because of widespread, ambient contamination that cannot be cleaned up using treatment methods reasonably employed by public water 
supply systems (40 CFR $5192.11(e)$ (1994)). Although supplemental standards are being applied, the potential use of ground water in the site vicinity will be protected. 
TABLE OF CONTENTS

Section

Page

1.0 INTRODUCTION ............................ 1-1

1.1 Ground water compliance strategy .................... 1-1

1.2 Relationship to other ground water documents ............ 1-1

1.3 SowP revisions ............................ 1-2

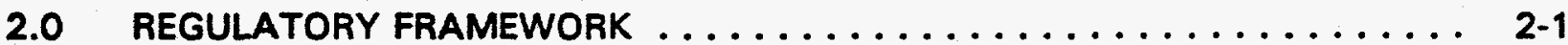

2.1 Uranium mill tailings radiation control act $\ldots \ldots \ldots \ldots \ldots \ldots \ldots \ldots . \ldots . . \ldots$

2.1.1 EPA ground water compliance standards ............ 2-1

2.1.2 Cooperative agreements ................. 2-4

2.2 National environmental policy act .................. 2-4

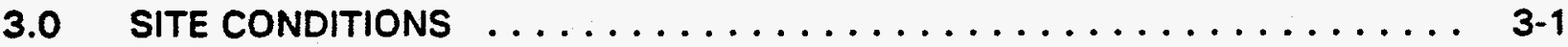

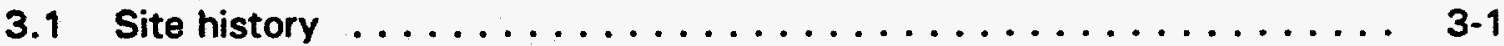

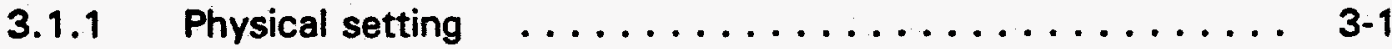

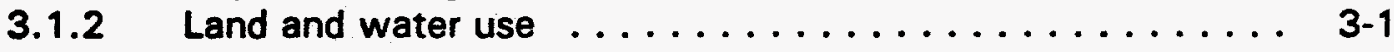

3.1.3 History of operations .................. 3-1

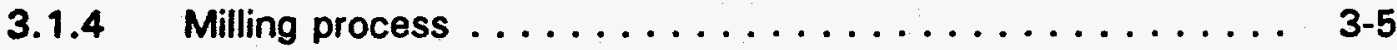

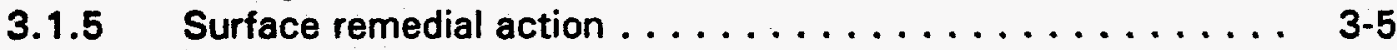

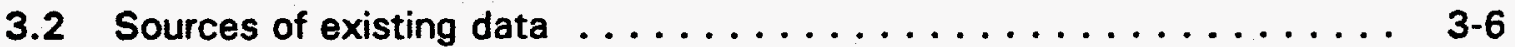

3.3 Conceptual site model . . . . . . . . . . . . . . . . . 3-7

3.3.1 Hydrogeologic setting ... . . . . . . . . . . . . . 3-9

3.3.2 Background ground water quality ............. 3-16

3.3.3 Magnitude of site-related ground water contamination . . . . 3-34

3.3.4 Contaminant fate and transport ............. 3-36

3.3.5 Risk evaluation . . . . . . . . . . . . . . . 3-38

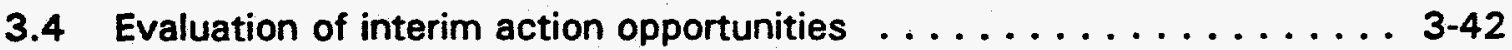

4.0 GROUND WATER COMPLIANCE STRATEGY SELECTION $\ldots \ldots \ldots \ldots \ldots$

4.1 Compliance strategy selection process . . . . . . . . . . . . . 4-1

4.2 Falls City, Texas compliance strategy selection . . . . . . . . . . . . 4-1

4.3 Deviations, contingencies, and decision rules . . . . . . . . . . . 4-6

5.0 DATA COLLECTION AND ASSESSMENT $\ldots \ldots \ldots \ldots \ldots \ldots \ldots \ldots \ldots \ldots \ldots$

5.1 Statement of data needs . . . . . . . . . . . . . . . . . 5-1

5.1.1 Qualitative analysis of background ground water quality ... 5-1

5.1 .2 Land and water use survey .............. 5-1

$5.1 .3 \quad$ Hydrogeologic investigations ................ 5-1

5.1.4 Geochemical analysis of subsurface samples .......... 5-2

5.2 Data collection objectives .................... 5-2

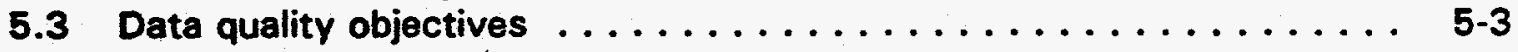

5.3.1 Qualitative analysis of background ground water quality ... 5-3

5.3.2 Land and water use survey ............... 5-3

5.3.3 Hydrogeologic investigations ............... 5-3

5.3.4 Geochemical analysis of subsurface samples ......... 5-5 


\section{TABLE OF CONTENTS (Concluded)}

Section

Page

5.4 Data collection activities .................... 5-5

5.4.1 Qualitative analysis of background ground water quality .. 5-5

5.4 .2 Land and water use survey .............. 5-6

5.4.3 Hydrogeologic investigations . . . . . . . . . . . 5-6

5.4.4 Geochemical analysis of Deweesville/Conquista

sediments ........................ 5-11

5.5 Results and evaluation of data collection activities ........... 5-11

$6.0 \quad$ LIST OF CONTRIBUTORS . . . . . . . . . . . . . . . . 6-1

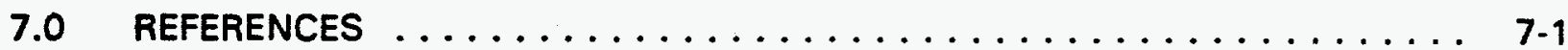

\section{APPENDIX}

CALCULATION FCT-06-91-12-01-00 


\section{LIST OF FIGURES}

Eiqure

Page

3.1 Location of the Falls City, Texas, site . . . . . . . . . . . . . . . . 3-2

3.2 Topographic map of the disposal site area . . . . . . . . . . . . . . . . 3-3

3.3 Locations of monitor wells, former tailings piles, and disposal cell, Falls City, Texas, site . . . . . . . . . . . . . . . . . . . . . . . . . 3-8

3.4 Surface geology and cross section locations, Falls City, Texas, site . . . . . 3-10

3.5 Cross section of uppermost aquifer A-A', Falls City, Texas, site . . . . . . . 3-11

3.6 Potentiometric surface of the Deweesville/Conquista aquifer, Falls City, Texas, site . . . . . . . . . . . . . . . . . . . . . . 3-14

3.7 Locations of the Dilworth background wells and the Deweesville/Conquista Conoco 600 series wells, Falls City, Texas, site . . . . . . . . . . . . . 3-19

3.8 Trilinear plot of data from Deweesville/Conquista monitor wells 667, 668, and selected Hobson monitor wells, Falls City, Texas, site . . . . . . . . . 3-25

3.9 Trilinear plot of Dilworth background ground water and Deweesville/ Conquista reference water, Falls City, Texas, site . . . . . . . . . . . 3-26

3.10 Approximate distribution of tailings-contaminated ground water in Deweesville/Conquista aquifer, Falls City, Texas, site . . . . . . . . 3-35

4.1 Framework application of contaminants of potential concern in the Dilworth and Deweesville/Conquista . . . . . . . . . . . . . . . . . . . . 4-2

5.1 Areal coverage of land and water use survey $\ldots \ldots \ldots \ldots \ldots \ldots \ldots$

5.2 Proposed monitor well locations . . . . . . . . . . . . . . . . . . 5-9 


\section{LIST OF TABLES}

Table

Page

2.1 Maximum concentration of inorganic constituents for ground water

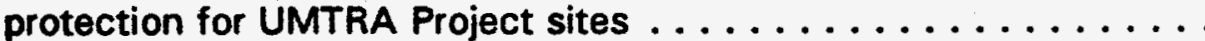

3.1 Typical water quality data for Dilworth and Deweesville/Conquista background wells

3.2 Water quality in the Deweesville/Conquista aquifer at the Falls City, Texas, site

3.3 Statistical summary of the Dilworth ground water quality at the Falls City, Texas, site . . . . . . . . . . . . . . . . . . . . . . 3-27

3.4 Contaminants of potential concern in the Dilworth aquifer . . . . . . . . . 3-40

4.1 Framework application of contaminants of potential concern for the Dilworth aquifer .......................... 4-4

5.1 Construction summary of proposed monitor wells $\ldots \ldots \ldots \ldots \ldots$ 


\section{* LIST OF ACRONYMS AND ABBREVIATIONS}

Acronym Definition

ac

$A C L$

ASTM

$\mathrm{cm} / \mathrm{s}$

DOE

DQO

EA

EPA

FM

ft

GPS

ha

m

MCL

$\mathrm{mg} / \mathrm{L}$

$\mathrm{mi}$

$\mathrm{mm}$

NEPA

NRC

PEIS

PVC

QA

RAP

RRM

SOP

SOWP

SW

TAC

TKA

tpd

$\mathrm{U}_{3} \mathrm{O}_{8}$ UMTRA

UMTRCA

USGS acre

alternate concentration limits

American Society for Testing Materials

centimeters per second

U.S. Department of Energy

data quality objectives

environmental assessment

U.S. Environmental Protection Agency

Farm-to-Market

feet

global positioning system

hectare

meters

maximum concentration limits

milligrams per liter

mile

millimeter

National Environmental Policy Act

U.S. Nuclear Regulatory Commission

programmatic environmental impact statement

polyvinyl chloride

quality assurance

remedial action plan

residual radioactive materials

standard operating procedures

site observational work plan

Susquehanna-Western, inc.

Technical Assistance Contractor

Turk, Kehle \& Associates

ton per day

uranium oxide

Uranium Mill Tailings Remedial Action

Uranium Mill Tailings Radiation Control Act

U.S. Geological Survey 


\subsection{INTRODUCTION}

Produced by the U.S. Department of Energy (DOE), this site observational work plan (SOWP) initiates field activities for the Ground Water Project phase of the Uranium Mill Tailings Remedial Action (UMTRA) Project at the Falls City site. The Falls City SOWP, presents a comprehensive summary of site hydrogeological data, delineates a conceptual model of the aquifer system, and discusses the origins of milling-related ground water contamination. It also defines the magnitude of ground water contamination, potential environmental and health risks associated with ground water contamination and data gaps, and identifies an appropriate compliance strategy.

\subsection{GROUND WATER COMPLIANCE STRATEGY}

The proposed ground water compliance strategy for the Falls City site is no action, with an application for supplemental standards based on the following criteria:

- The ground water is considered Class III ground water (52 FR 36008 (1987)1. Class 111 ground water is ground water that is not a current or potential source of drinking water because widespread ambient contamination cannot be cleaned up with treatment methods reasonably employed by public water supply systems (40 CFR \$192.11(e)(1994)). However, U.S. Environmental Protection Agency (EPA) regulations require the DOE to consider the impact of milling contamination on current or future beneficial uses of ground water. In Falls City, potential beneficial uses would be limited to watering livestock and gardens, because the quality of naturally occurring ground water is poor and the yield is low. sites. Section 3.0 provides site-specific data that support the ground water compliance strategy. Section 4.0 justifies the ground water compliance strategy.

\subsection{RELATIONSHIP TO OTHER GROUND WATER DOCUMENTS}

The programmatic documents that guide the SOWP include the UMTRA Groundwater Program Plan (DOE, 1992a) the Programmatic Environmental Impact Statement (PEIS) (DOE, 1994a), and Technical Approach to Groundwater Restoration (DOE, 1993a). The Groundwater Program Plan states the mission and objectives of the UMTRA Project Ground Water Program and provides a technical and management approach for conducting the program. The PEIS is a programmatic decision-making framework for conducting the UMTRA Ground Water Project. The DOE will follow the PEIS guidelines to assess the potential programmatic impacts of the Ground Water Project, to determine site-specific ground water compliance strategies, and to prepare site-specific environmental impacts analyses more efficiently. Technical guidelines for conducting the ground water program are found in the Technical Approach to Ground Water Restoration. 
A draft base line risk assessment for the Falls City site will be issued in 1994. The findings and recommendations in that assessment will help define data deficiencies that can be addressed in this SOWP. Additional data will be collected to help identify potential future hazards at the site and to assess the impacts of milling-related contamination on current or future use of ground water in the site vicinity.

The environmental impacts of the action proposed here will be analyzed in an environmental assessment (EA) that will meet the requirements of the National Environmental Policy Act (NEPA) (42 USC $\$ 4321$ et seq.) and will be based on PEIS guidance.

\subsection{SOWP REVISIONS}

A summary of existing data, a conceptual model, a recommended compliance strategy based on this conceptual model, and data needed to further support the selected strategy are presented in this SOWP. This document will be revised as more information is collected. The final document will describe and correlate the additional data to previous information; update the site conceptual model; and, if necessary, revise the ground water compliance strategy. 


\subsection{REGULATORY FRAMEWORK}

This section identifies the requirements for selecting a ground water compliance strategy for the Falls City, Texas, processing site to achieve compliance with Subpart B of the EPA health and environmental protection standards for uranium and thorium mill tailings 140 CFR Part 192 (1994)), and the associated proposed 1987 standards published in 52 FR 36000 (1987).

\subsection{URANIUM MILL TAILINGS RADIATION CONTROL ACT}

The United States Congress passed the Uranium Mill Tailings Radiation Control Act (UMTRCA) (42 USC $\$ 7901$ et seg.) in 1978 in response to public concerns about potential health hazards from long-term exposure to uranium mill tailings. The UMTRCA authorized the DOE to stabilize, dispose of, and control uranium mill tailings and other contaminated materials at inactive uranium mill processing sites.

The UMTRCA is divided into three sections (titles). Title I designates 24 inactive processing sites for remediation. It directs the EPA to promulgate

3. standards; mandates remedial action in accordance with these standards;

*. stipulates the U.S. Nuclear Regulatory Commission (NRC), states, and Indian tribes must concur on the remedial action; directs the NRC to license the disposal sites; and directs the DOE to enter into cooperative agreements with the affected states and Indian tribes. Title $I$ applies to active uranium mills. Title III applies only to certain uranium mills in New Mexico. The UMTRA Project is responsible for administering only Title I of the UMTRCA.

In 1988, Congress passed the Uranium Mill Tailings Remedial Action Amendments Act (Amendments Act) (42 USC $\$ 7922$ et seq.), authorizing the DOE to extend without limitation the time needed to complete ground water remediation activities at the processing sites. Section 108 of the UMTRCA requires the DOE to comply with the proposed EPA standards in the absence of final standards.

\subsubsection{EPA ground water compliance standards}

The UMTRCA requires the EPA to promulgate standards for protecting public health, safety, and the environment from radiological and nonradiological hazards associated with uranium processing and the resulting residual radioactive materials (RRM). On January 5, 1983, the EPA published standards (40 CFR Part 192 (1994)) for RRM disposal and cleanup. The EPA proposed new standards to replace remanded sections, and changed the ground water standards of 40 CFR Part 192. These proposed standards were published in the Federal Register on September 24, 1987 (52 FR 36000 (1987)).

The proposed standards address two ground water contamination scenarios: the first addresses future ground water contamination that might occur from 
tailings piles after disposal. The second addresses the cleanup of contamination that occurred at the processing sites before disposal of the tailings piles (52 FR 36001 (1987)). The UMTRA Surface Project is designed to protect the ground water at the disposal sites. The Ground Water Project addresses the contamination at the processing sites and is regulated by Subparts $B$ and $C$ of the proposed EPA standards.

Subpart B, "Standards for Cleanup of Land and Buildings Contaminated with Residual Radioactive Materials From Inactive Uranium Processing Sites," requires remedial action at the former processing sites to ensure the RRM in ground water meets any of three criteria in 52 FR 36000 (1987). Subpart B also allows natural flushing to meet the proposed standards. Natural flushing allows natural ground water processes to reduce the contamination in ground water to acceptable standards (background levels, maximum concentration limits $[M C L]$, or alternate concentration limits [ACL]). Natural flushing must allow the standards to be met within 100 years. In addition, institutional controls to protect human health and an adequate monitoring program must be established and maintained during the period of natural flushing; institutional controls restrict access to contamination. The ground water also must not be a current or projected source of drinking water during the period of natural flushing (40 CFR \$192.12(c)(4) (1994)).

Subpart C, "Implementation," provides the supplemental standards described below.

- Background levels. Concentrations of constituents in nearby ground water that was not contaminated by processing activities.

- Maximum concentration limits. Maximum concentrations set by the EPA for certain hazardous constituents in ground water, proposed for the UMTRA Project (Table 2.1)

- Alternate concentration limits. An alternate concentration limit for a hazardous constituent that does not pose a substantial hazard (present or potential) to human health or the environment.

Subpart $C$ provides guidance for implementing methods and procedures to reasonably ensure the provisions of Subpart B are satisfied. Subpart $C$ requires the following:

- The conditions of Subpart B must be met on a site-specific basis, using information gathered during site characterization and monitoring. The plan to meet the conditions of Subpart B must be stated in a site-specific compliance strategy plan or remedial action plan (RAP); either plan must contain a compliance strategy and a monitoring program and must demonstrate effectiveness. 
Table 2.1 Maximum concentration of inorganic constituents for ground water protection for UMTRA project sites

\begin{tabular}{|c|c|}
\hline Constituent & Maximum concentration $^{a}$ \\
\hline Arsenic & 0.05 \\
\hline Barium & 1.0 \\
\hline Cadmium & 0.01 \\
\hline Chromium & 0.05 \\
\hline Lead & 0.05 \\
\hline Mercury & 0.002 \\
\hline Molybdenum & 0.1 \\
\hline Nitrate (as N) & $10.0^{b}$ \\
\hline Selinium & 0.01 \\
\hline Silver & 0.05 \\
\hline Combined radium- 226 and radium -228 & $5 \mathrm{pCi} / \mathrm{liter}$ \\
\hline Combined uranium-234 and uranium-238 & $30 \mathrm{pCi} / \mathrm{liter}^{\mathrm{c}}$ \\
\hline Gross alpha-particle activity (excluding radon and uranium) & $15 \mathrm{pCi} /$ liter \\
\hline
\end{tabular}

${ }^{a}$ Concentrations reported in milligrams per liter $(\mathrm{mg} / \mathrm{L})$ unless otherwise noted.

bquivalent to $44 \mathrm{mg} / \mathrm{L}$ nitrate as nitrate.

Equivalent to $0.044 \mathrm{mg} / \mathrm{L}$.

pCi - picocuries.

Ref: 52 FR 36007 (1987). 
Subpart $C$ also describes conditions under which the DOE may apply supplemental standards to contaminated ground water rather than meet background levels, MCLs, or ACLs. The standards define Class III (limited use) ground water as ground water that is not a current or potential source of drinking water because total dissolved solids (TDS) exceed 10,000 milligrams per liter (mg/L); widespread ambient contamination cannot be cleaned up using treatment methods reasonably employed by public water supply systems; or the quantity of water available is less than 150 gallons (570 liters) per day (40 CFR $\$ 192.11(e)(1994))$. Subpart C requires the DOE to inform private owners and occupants of the area affected by hazardous constituents and solicit their comments before applying supplemental standards. The DOE is planning a public participation program in Falls City to meet the requirements of Subpart C.

The DOE proposes a no remediation-supplemental standards compliance strategy for the Falls City. Texas, site. This strategy will achieve compliance with the proposed EPA ground water standards applicable to Title I UMTRA Project sites. To protect ground water and to achieve compliance with the proposed EPA ground water standards under Subpart A (UMTRA Surface Project), a narrative supplemental standard for the Falls City site was proposed and approved. The supplemental standard application for the surface remedial action was based on widespread ambient contamination that could not be cleaned up with methods reasonably employed by public water supply systems. Therefore, the DOE concluded that ground water in the uppermost aquifer meets the widespread ambient contamination criteria of Class III ground water. The NRC and the state of Texas concurred with the DOE ground water protection strategy for the UMTRA Surface Project in 1992. Thus, the Falls City ground water compliance strategy (to meet Subpart B requirements) is identical to the Surface Project ground water protection strategy. The regulatory drivers that guide the selection of the proposed ground water compliance strategy for the Falls City. Texas, site and all other UMTRA sites are identified below.

\subsubsection{Cooperative agreements}

The UMTRCA requires that remedial action include full participation of the states and Indian tribes that own land containing the uranium mill tailings. The UMTRCA also directs the DOE to enter into cooperative agreements with the states and Indian tribes.

\subsection{NATIONAL ENVIRONMENTAL POLICY ACT}

The UMTRCA is a major NEPA activity (42 USC $\$ 4321$ et seq.). Regulations of the Council on Environmental Quality (to implement the NEPA) are codified in 40 CFR Part 1500 (1994); these regulations require each federal agency to develop its own implementing procedures (40 CFR $\$ 1507.3$ (1994)). The DOErelated NEPA regulations are contained in 10 CFR Part 1021 (1994), National Environmental Policy Act; Implementing Procedures. Guidance is provided in Recommendations for the Preparation of Environmental Assessments and Environmental Impact Statements (DOE, 1993b). 
Pursuant to the NEPA, in 1994 the DOE drafted a PEIS for the UMTRA Ground Water Project to analyze the potential impacts of implementing four programmatic alternatives for ground water compliance at the designated processing sites. The DOE will select the preferred alternative for the UMTRA Ground Water Project; this alternative will be published in a record of decision. All subsequent action on the UMTRA Ground Water Project must comply with this record of decision. 


\subsection{SITE CONDITIONS}

The following section discusses past uranium mining and milling activities at and in the vicinity of the site, the surface remedial action, and the status of surface cleanup efforts. Site characterization data are summarized and the site conceptual model is presented. The site conceptual model is based on the ground water characterization data, while the conceptual model enhances understanding of contaminant fate and transport, exposure pathways, risk to public health and the environment, and the remediation strategy. The model also provides the rationale for the proposed ground water remedial action strategy.

Hydrogeologic and geochemical characterization efforts at the Falls City site began before surface cleanup of the site began and continued throughout surface remedial action. Thus, sufficient data are available to propose a conceptual model for the former processing site. Section 3.3 presents a conceptual model and discusses contaminant fate and transport.

\section{$3.1 \quad$ SITE HISTORY}

\subsubsection{Physical setting}

\subsubsection{Land and water use}

Most of the land surrounding the former processing site is used for cattle grazing and dry farming. Local residents primarily grow hay and other livestock feed crops. Most livestock in the site area are beef cattle; some residents keep small pouitry flocks.

The Deweesville/Conquista and the Dilworth aquifers are not used as domestic or potable water supplies in the immediate site vicinity, although the Dilworth aquifer is used to water stock within a $2-\mathrm{mi}(3-\mathrm{km})$ radius of the site (DOE, 1992b). The Three Oaks Water Company supplies residences within the site area with water from a Carrizo Sandstone well. This well is 2000 feet ( $f t)$ (600 meters [m]) deep and is approximately $10 \mathrm{mi}(16 \mathrm{~km})$ northwest of the site. Livestock are watered primarily from surface collection tanks or stock ponds.

\subsubsection{History of operations}

In late 1955, the Climax Molybdenum Company identified uranium ore deposits averaging 0.20 percent uranium oxide $\left(\mathrm{U}_{3} \mathrm{O}_{8}\right)$ in an area $8 \mathrm{mi}(13 \mathrm{~km})$ west of 


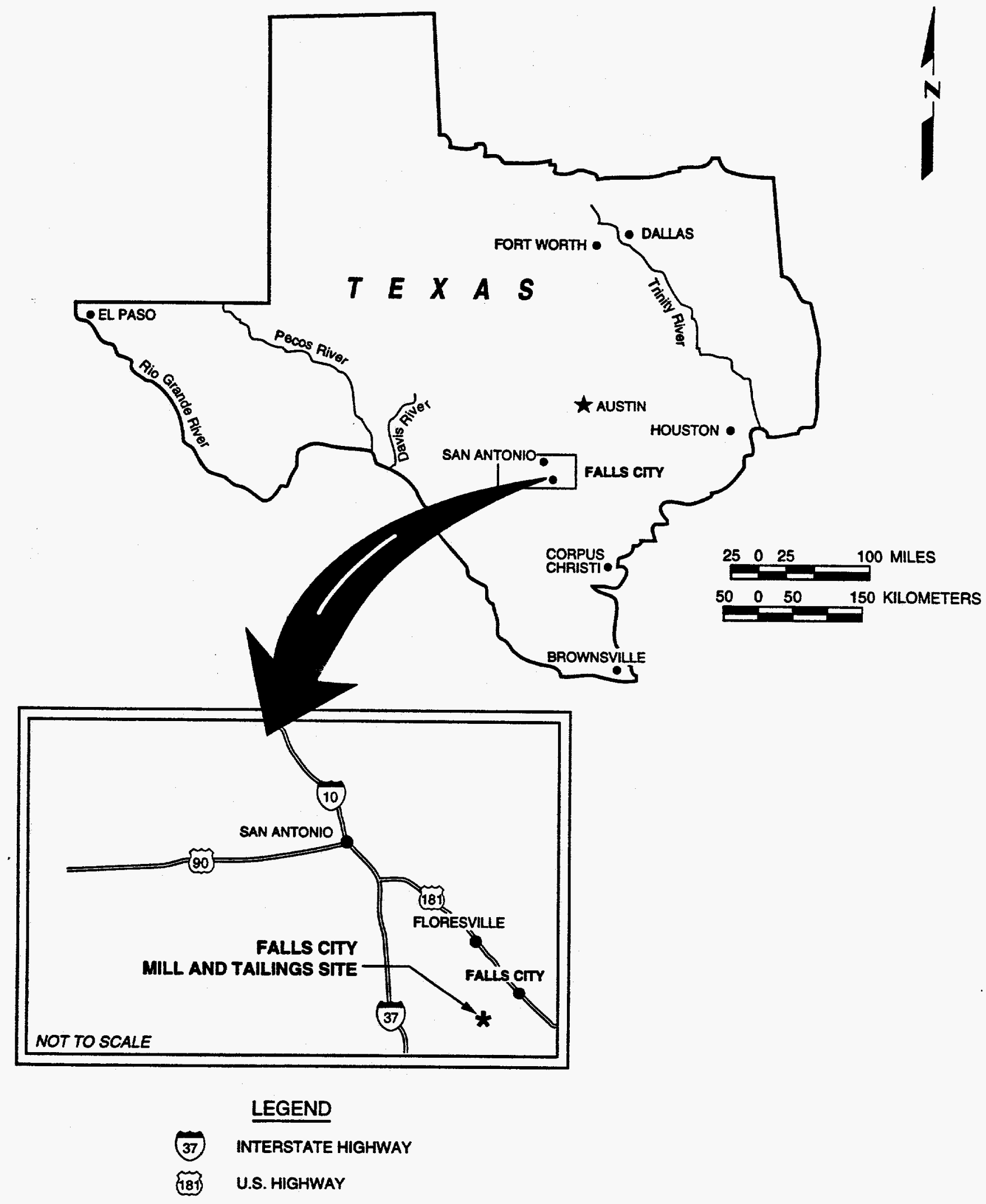

FIGURE 3.1

LOCATION OF THE FALLS CITY, TEXAS, SITE 


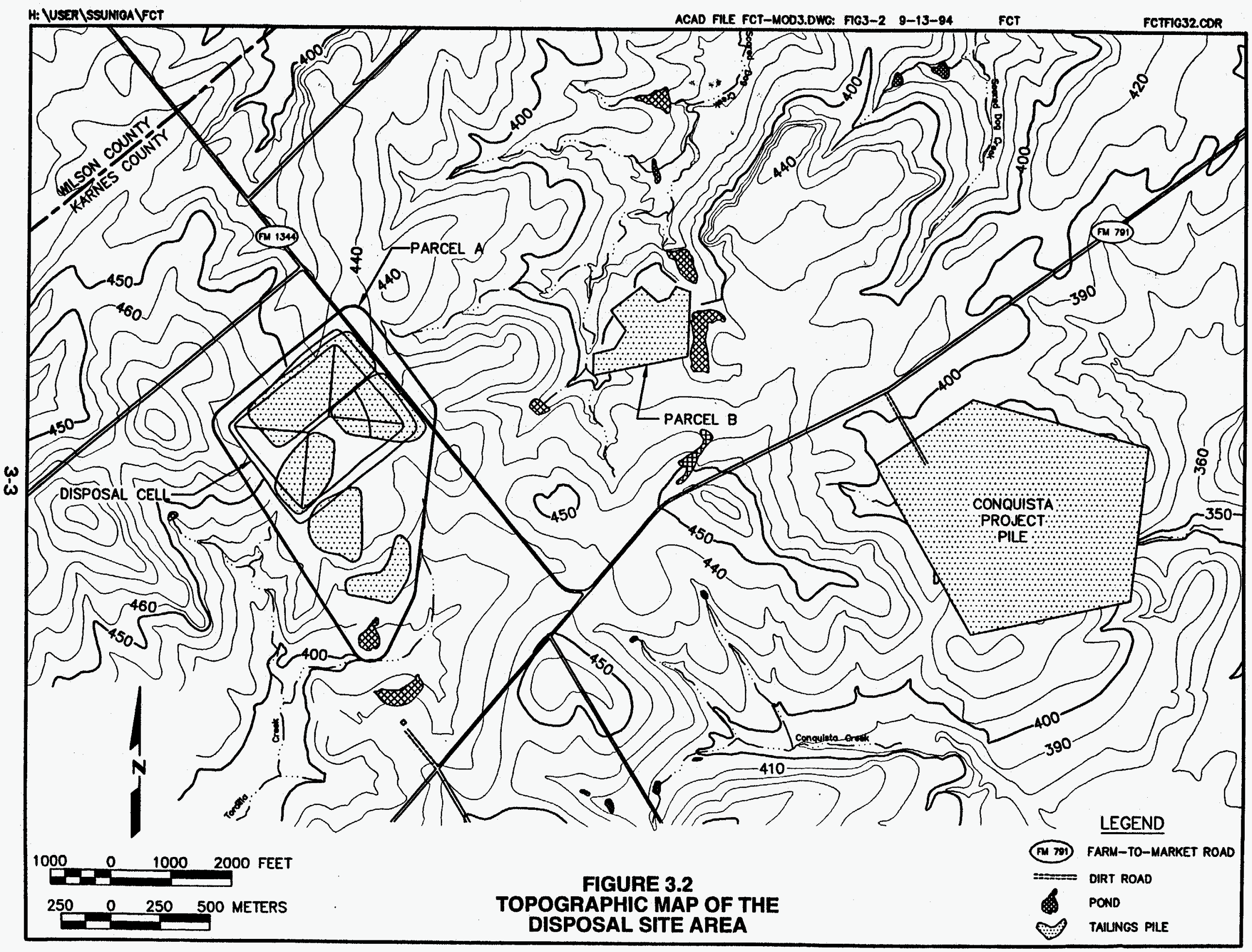


Falls City. Open pit mining occurred from 1959 to 1960 and was completed when Susquehanna-Western, Inc. (SWI), acquired the property as a mill site in 1961. Open pit mining occurred at the former locations of piles 3, 4, 5, and 6 . The mill was constructed as a nominal 300-ton-per-day (tpd) operation, but operated at 220 tpd from April 1961 until early 1968 (Merritt, 1971). In 1968, the mill expanded to operate at 900 tpd and, for short periods up to 1000 tpd (Merritt, 1971). In August 1973, the mill ceased operations, having treated 2.5 million tons (2.3 million tonnes) of ore (FBDU, 1981).

During mill operations, ground water from a well adjacent to the mill building was the only source of processing water. The well was $3650 \mathrm{ft}(1110 \mathrm{~m})$ deep in the Carrizo Sandstone; the state plugged and abandoned the well in 1991.

An SWI solid waste registration application submitted in 1973, stated that fresh water consumption ranged from 50 to 150 gallons (190 to 570 liters) per minute. Consumption depended on the ore, amount of rainfall, tailings pond solution available for recycle (in 1973 ponded water from tailings pile 7 was the only solution in active use), and reagent consumption required by the process. SWI also stated in the application that " $75 \mathrm{gpm}$ [gallons per minute] fresh water consumption may be considered a fair average." This measurement represents a net discharge to tailings pile 7 at approximately 121 acre (ac)-ft per year. The ponds on the tailings piles were not lined but sumps along the pile perimeters pumped runoff and seepage back to the tailings piles. During mill operation (1961 to 1973), approximately 865 ac-ft of ore-processing water and precipitation that fell on the ponds might have infiltrated the Deweesville/Conquista aquifer. This calculation is included as an Appendix to this document.

At the completion of SWI operations in 1973, a 40-ac (16-hectare [ha]) pond had been created at the top of pile 7. The liquids in this pond were acidic raffinates. In August 1978, Solution Engineering, Inc., of Alice, Texas, initiated in situ extraction mining on the tailings piles, installing an injection/withdrawal system in pile 7. Fluids from the raffinate pond were injected to a depth of 30 to $45 \mathrm{ft}$ ( 9 to $14 \mathrm{~m}$ ) at a rate of about 500 gallons (1900 liters) per minute. Between 300 and 550 gallons (1140 to 2100 liters) per minute of fluids were extracted from the pile; these uranium-bearing solutions were processed at the mill. Eventually, the operation expanded to piles 1, 2, 4, and 5 . In situ solution mining ended in February 1982. In 1983, after 3.5 years of leeching operations, the state of Texas annulled Solution Engineering's operating license and directed the company to conduct interim restoration activities. Interim restoration consisted of spray-evaporating the large ponds on top of piles 7 and 2, capping piles 7 and 2 with a 1 - to 2-ft (0.3- to $0.6-\mathrm{m})$-thick clay cover, and dismantling the mill. The interim restoration was completed in 1986 and probably reduced the rate of pore fluid seepage into the aquifer (DOE, 1992b). 


\subsubsection{Milling process}

An acid-leach countercurrent-decantation solvent-extraction system extracted and concentrated the uranium (as $\mathrm{U}_{3} \mathrm{O}_{8}$ ). This process is described below (Merritt 1971).

Sulfuric acid was added as a leaching agent to the ore slurry, producing a slurry with a pH near 1.0. A five-stage, countercurrent washing circuit included a polyacrylamide-type flocculent to assist in separating the slimes from the process stream. The solvent extraction circuit included an organic solution containing $\mathbf{7 . 5}$ percent tertiary amine and $\mathbf{2 . 5}$ percent isodecanol in kerosene. Uranium was stripped from the loaded organic with either a sodium carbonate or acidified sodium chloride solution. The final uranium product ("yellow cake") was precipitated by adding caustic soda.

\subsubsection{Surface remedial action}

Remedial action consolidated and stabilized 7.0 million tons (6.4 million tonnes) of tailings and contaminated materials into a disposal cell covering 132 ac $(53.4 \mathrm{ha}$ ) in the vicinity of piles 7 and 2 . The approximate footprint of these piles is $2600 \times 2200 \mathrm{ft}(790 \times 670 \mathrm{~m})$. At least 30 monitor wells within or around the construction area were decommissioned (cutoff and grouted) during surface remedial action.

- The DOE is required to demonstrate that RRM surface cleanup and disposal will not impact (or further impact) ground water in the vicinity of the former processing site. Thus, the NRC required that the site-specific RAP include a ground water protection strategy.

To protect the ground water and to achieve compliance with the proposed EPA ground water standards, a narrative supplemental standard for the Falls City site was proposed. The supplemental standard for the surface remedial action was based on widespread ambient contamination that could not be cleaned up using methods reasonably employed by public water supply systems. Also, there were few potential beneficial uses of the ground water due to poor quality and low yield. Historically, the uppermost aquifer was not used as a drinking water source because of poor quality and low yield. Because the ground water quality is so poor (TDS $7500 \mathrm{mg} / \mathrm{L}$ ) in the upper aquifers, they are rarely used, and only as a water source for limited stock watering and occasional home garden irrigation. Therefore, ground water in the uppermost aquifers meets the widespread ambient contamination criterion of Class III ground water (DOE, 1992b).

The NRC and the state of Texas concurred with the surface RAP and ground water protection strategy in September 1992. Surface remedial action was completed in April 1994. 


\subsection{SOURCES OF EXISTING DATA}

The UMTRA Project and other investigators conducted several hydrologic, geologic, and geochemical studies at and in the vicinity of the Falls City processing site.

Bunker and MacKallor (1973), in a U.S. Geological Survey (USGS) report, describe the geology of uranium ore deposits in the Falls City area, based largely on data from the exploratory drilling programs conducted in the late 1950s. The USGS report includes detailed discussions of the stratigraphy and mineralogy of several ore deposits in the Tordilla Hill-Deweesville area, including the two deposits (Nuhn and Luckett) mined at the Falls City site (open pit mines).

Kallus (1975) prepared a report for the EPA Region VI on the general environmental impacts of uranium mining and milling in the South Texas uranium district. This report summarized surface and ground water monitoring data compiled from USGS and Texas Water Quality Board records. Ground water data were derived from approximately 100 samples, with complete chemical analyses performed on one-third of the samples. Kallus found highly variable natural levels of radioactivity, arsenic, molybdenum, and selenium in South Texas ground water. The only reported health impact from uranium mining was molybdenosis in cattle that grazed in runoff-contaminated areas near overburden piles.

Turk, Kehle \& Associates (TKA) conducted the first site-specific hydrogeologic study at the Falls City mill site in 1976 (TKA, 1976). This study was a reconnaissance-level investigation that relied on existing water level and water quality data from 26 monitor wells around the site, and included a general characterization of the local climate, geology, surface water quality, and ground water conditions. The TKA study concluded radioactive contamination (gross alpha and beta activity) was not evident in the aquifer system beneath the site.

Ford, Bacon \& Davis Utah Inc. (FBDU, 1981) prepared an engineering assessment of the Falls City site that included field sampling of the 14 monitor wells Solution Engineering Inc. installed around the tailings piles. Analyses of samples from these wells indicated contamination of the shallow aquifer in the vicinity of the tailings piles.

In 1983, Geochemistry and Environmental Chemistry Research, Inc. (GECR, 1983) initiated a geochemical investigation of the Falls City site. Approximately 50 surface water and soil core samples were analyzed to define the extent of surficial contamination on and around the tailings piles. However, only two wells in the vicinity of the site were sampled.

The recent site characterization program conducted by the UMTRA Project included a three-phase hydrogeologic field investigation. In the first phase (December 1985 through May 1986), 39 new 4-inch (100 millimeter [mm]) 
polyvinyl chloride (PVC) cased monitor wells were installed and sampled; 25 existing wells were sampled, as well.

The second phase of the investigation (December 1988 through March 1990) was designed to gather supplemental data from the site to fill data gaps and achieve full compliance with the proposed EPA ground water protection standards. In addition, 12 additional monitor wells were installed at depths ranging from 40 to $230 \mathrm{ft}(2$ to $70 \mathrm{~m}$ ), completed primarily in the Dilworth Sandstone Member and the upper Manning Clay Formation; ground water from 50 to 55 monitor wells was sampled, including the 12 new wells and selected Conoco background wells in the site vicinity; and 16 lysimeters were installed to characterize the water quality of tailings fluids in piles $1,2,4,5,7$, and pond 6 .

Between 1990 and 1992, assisted by the Texas Bureau of Economic Geology, the UMTRA Project conducted a third phase of the field program to further characterize site geochemistry. The program included drilling 13 coreholes, analyzing the geochemistry of the cores, and installing 17 new monitor wells.

Domestic well surveys of a $2-\mathrm{mi}(3-\mathrm{km})$ radial area centered around the site were conducted in 1991 and in early spring 1994. The survey determined the historical and current use of ground water in the Deweesville/Conquista and Dilworth aquifers. Figure 3.3 shows locations of all wells drilled or sampled by the DOE at the Falls City site.

\section{$3.3 \quad$ CONCEPTUAL SITE MODEL}

A conceptual model of the site was developed to understand the site and to support the proposed ground water compliance strategies and remediation objectives. The conceptual model is summarized below; Sections 3.3 .1 through 3.3.5 provide details of the model.

Two low-yield (generally less than 1 gallon [4 liters] per minute) aquifers underlying the site have been identified: the Deweesville/Conquista and the Dilworth. The Deweesville and Conquista Members are grouped together as one aquifer because they are not separated by impermeable strata and there are no apparent restrictions in ground water movement between the two members.

Several investigators, including the Technical Assistance Contractor (TAC) and the Texas Bureau of Economic Geology, concluded the upper portions of the Deweesville/Conquista Formations (the subsurface at the processing site) historically were unsaturated and milling and in situ mining activities caused the current saturated conditions beneath the site. The TAC and the Texas Bureau of Economic Geology determined that processing and mining water created a ground water mound under the site and that ground water from the mound moves radially outward and downdip. The TAC used MODFLOW (USGS, 1988) to simulate ground water flow at the site; preliminary modeling results support the hydrologic representation of site conditions suggested by the TAC and Texas Bureau of Economic Geology. 


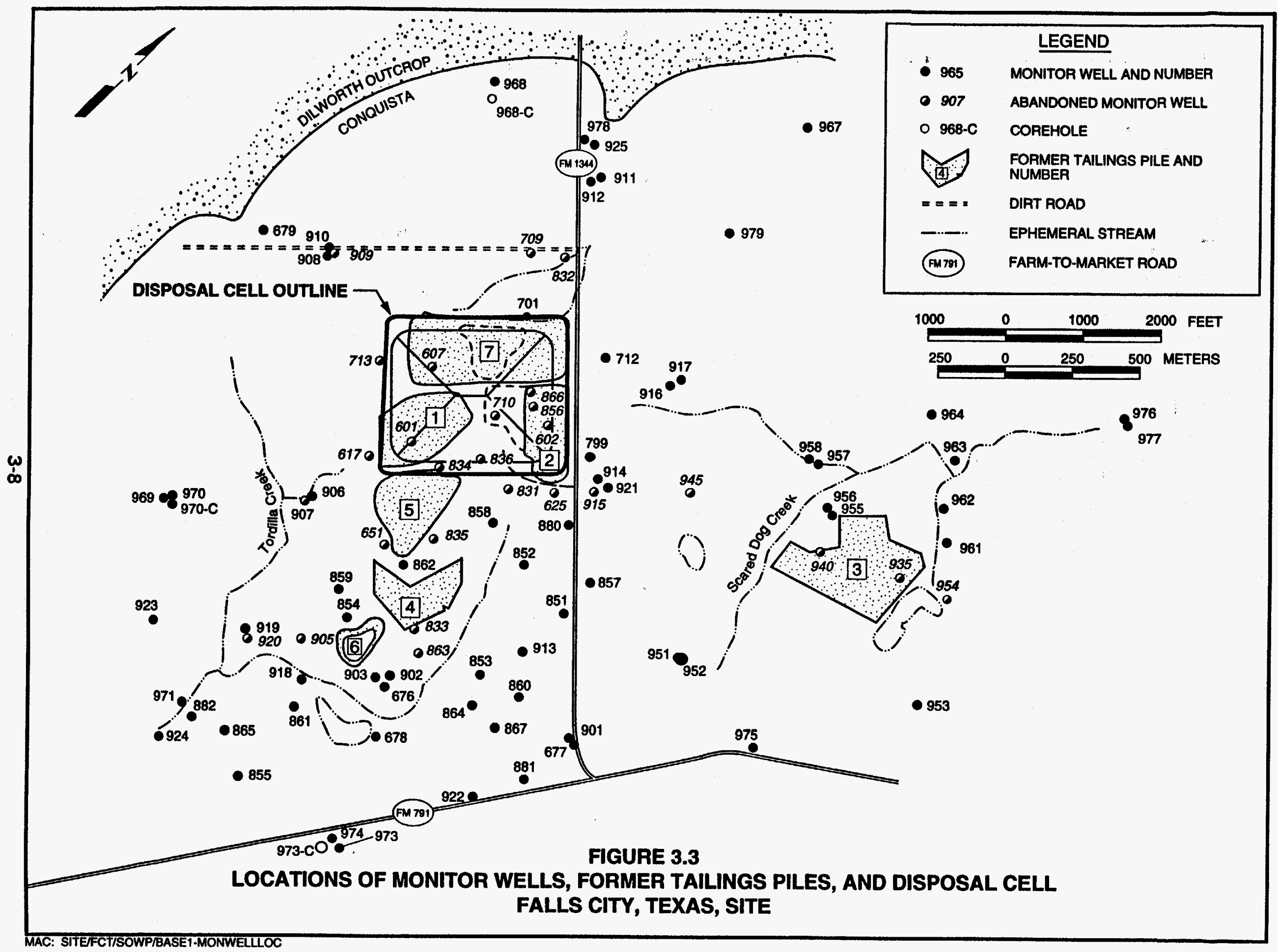


The principal ore-bearing unit at the site is the Deweesville Sandstone. Because the uranium mineralization associated with the ore bodies causes background ground water quality in both the Deweesville/Conquista and Dilworth aquifers to vary with depth and location, characterization of the ground water quality is difficult. Thus, the total understanding of geochemical conditions at the site is incomplete. However, the contaminants of concern in the aquifer that are related to the mill processing have been identified.

\subsubsection{Hydrogeologic setting}

The Falls City site is on the coastal plain of the Gulf of Mexico. The main topographic element in the Karnes County area is a series of ridges which trend

$\because$ predominantly northeast to southwest. These ridges are mainly cuestas (sloping plains) formed by resistant gulfward-dipping strata, although some river terrace gravels also form local topographic highs. Small intermittent streams follow the easily eroded strata between cuestas, producing a pronounced northeast trend in the drainage pattern in the site area. Relief from ridges to intervening drainage pathways generally is less than $100 \mathrm{ft}(30 \mathrm{~m})$ (TKA, 1976). Figure 3.2 presents a topographic map of the site area.

The mean annual precipitation in the site area is 30 inches $(760 \mathrm{~mm})$ (NOAA, 1979). Virtually all measurable precipitation is in the form of rain, which reaches monthly maxima in both May and September (NOAA, 1979). Most precipitation occurs as heavy rainfall during brief thunderstorms. This results in great spatial and temporal variability in rainfall distribution.

The Falls City site is underlain by clastic sedimentary strata that dip gently southeast (approximately $20 \mathrm{ft}$ per $1000 \mathrm{ft}$ ) as part of the thick homoclinal sequence of the Gulf Coastal Plain. The local sedimentary strata are comprised of generally unlithified sand, silt, and clay deposits of the Whitsett and Manning Clay Formations. The site rests on outcrops of the Dubose Clay, Deweesville Sandstone, and Conquista Clay Members of the Whitsett Formation (Figure 3.4). Tailings were placed in several old open pits excavated through the ore-bearing Deweesville and upper Conquista Members. Underlying the Conquista Clay is the Dilworth Sandstone Member, which, in turn, overlies the Manning Clay Formation, the oldest geologic unit encountered during the site drilling program. In addition, the site is on a surface and ground water divide. The divide is oriented west-northwest through the disposal cell area.

Three low-yield water-bearing strata are within the upper $200 \mathrm{ft}(60 \mathrm{~m})$ of the Whitsett Formation sediments underlying the site: 1) the Deweesville Sandstone Member; 2) the Conquista Clay Member; and 31 the Dilworth Sandstone Member. The Conquista Clay Member is composed of three subunits: an oxidized upper Conquista Clay/silt, the Conquista Sandstone, and a lower Conquista Clay (Figure 3.5). The Conquista Sandstone extends downdip into the subsurface, but thins significantly and becomes considerably finergrained. The Deweesville Sandstone Member, upper Conquista Clay, and Conquista Sandstone subunits are grouped together as one aquifer because 


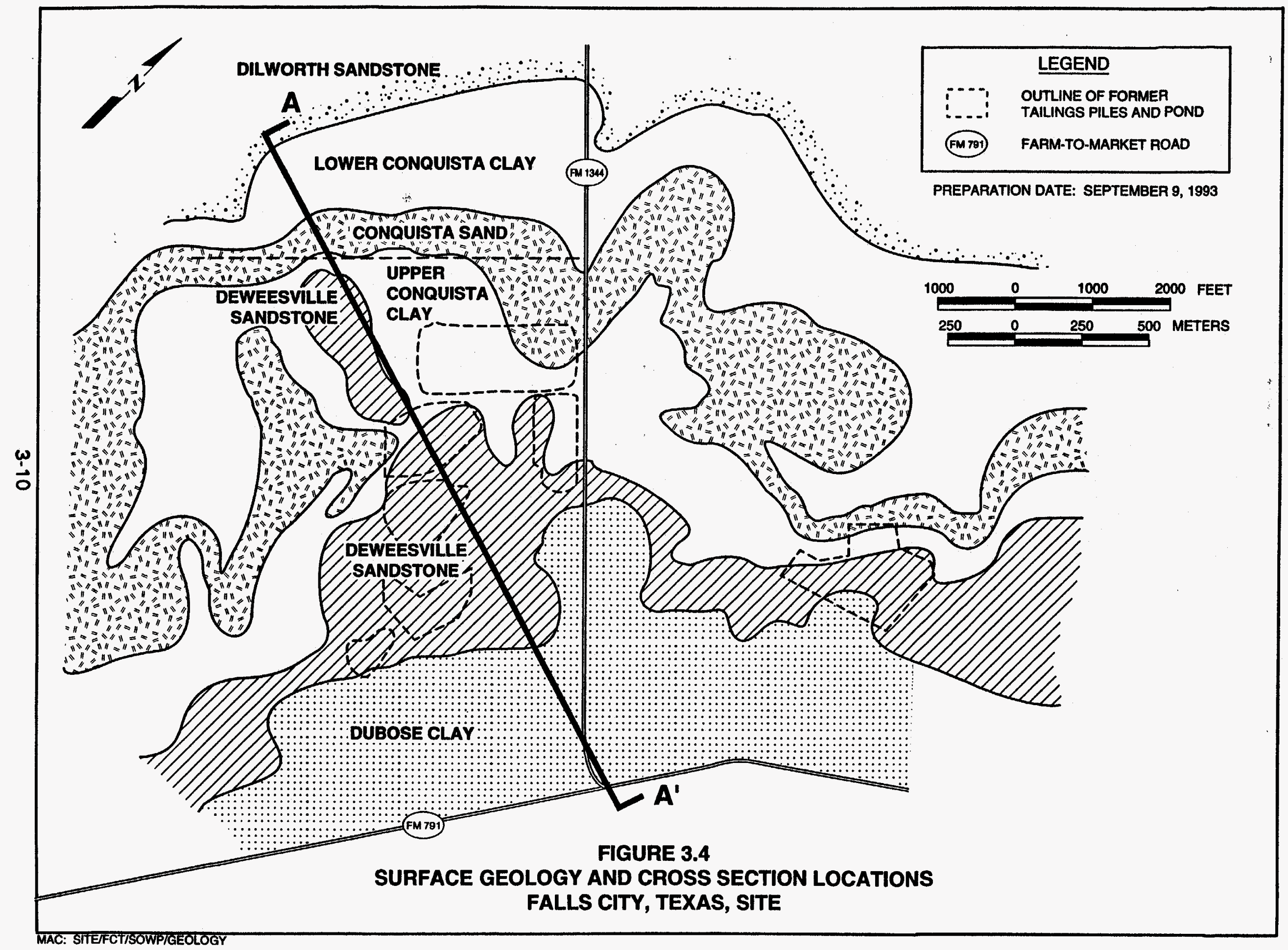




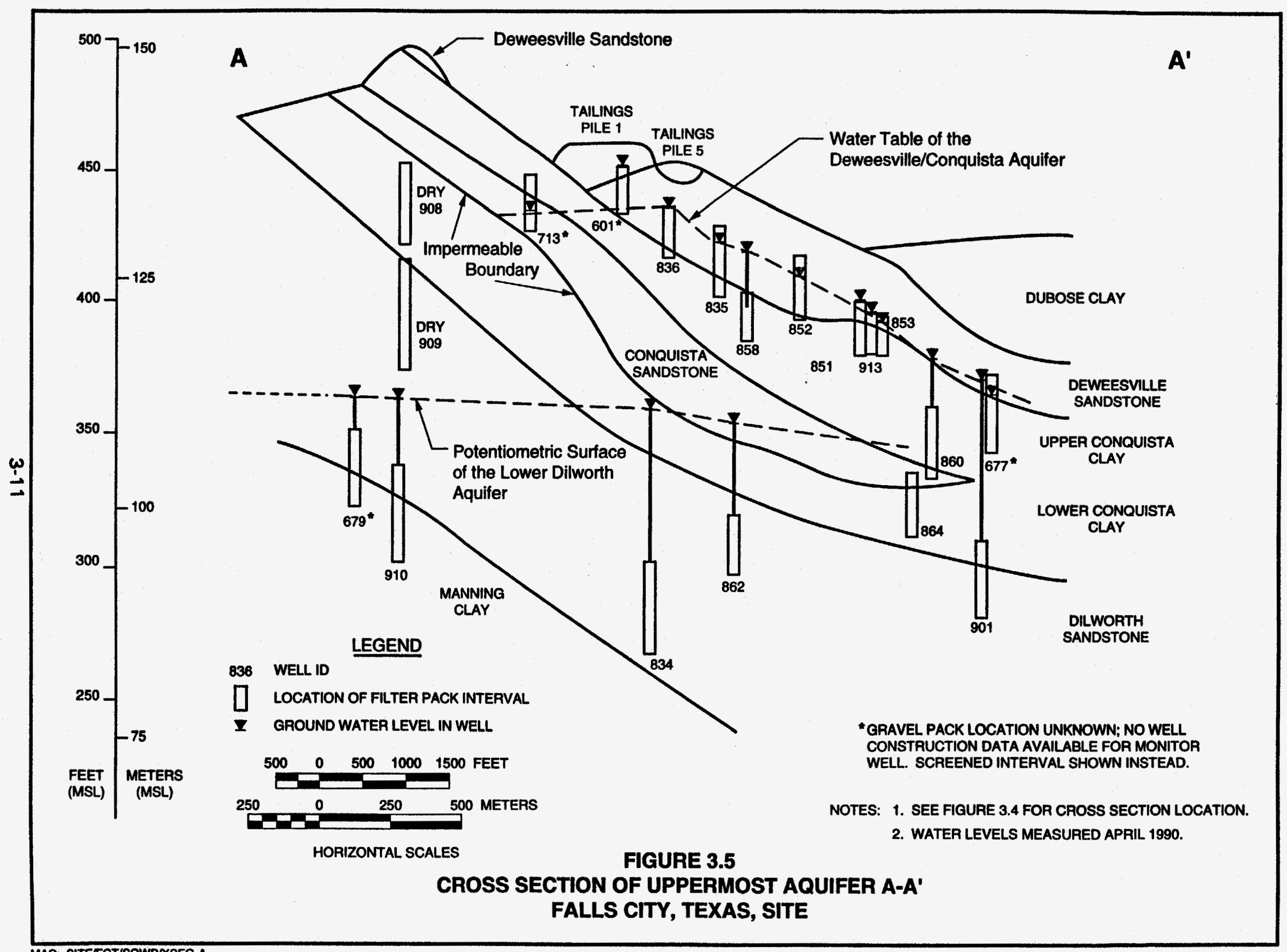


impermeable strata do not separate the members, with no apparent restrictions in ground water movement between the two members. Although the Deweesville/Conquista and Dilworth are referred to as aquifers in this document these members have never been developed as a source for drinking water supply, because of their low yield (generally less than 1 gallon [4 liters] per minute) and poor water quality.

\section{Deweesville/Conquista aquifer}

Shallow ground water in the site vicinity is found in the Deweesville/Conquista aquifer at depths of 5 to $30 \mathrm{ft}(2$ to $9 \mathrm{~m})$ below land surface. Ground water within the aquifer occurs under unconfined conditions in the northern and western portions of the site vicinity and along creek beds. In areas where the Deweesville/Conquista aquifer is unconfined, the potentiometric surface generally is a subdued replica of the surface topography.

The top of the lower Conquista Clay defines the lower boundary of the Deweesville/Conquista aquifer. The intersection of the Deweesville/Conquista water table and the top of the lower Conquista Clay marks the updip limit of saturation in the Deweesville/Conquista aquifer (Figure 3.5). Monitor wells 908 and 923 are completed updip of this intersection, and consequently, are dry. Because the tailings piles overlie outcrops of the Deweesville Sandstone and the upper Conquista Clay at the surface, it is impossible to install upgradient, background monitor wells screened in the Deweesville/Conquista aquifer.

Ground water within the Deweesville/Conquista aquifer is recharged by infiltrating precipitation in the Deweesville/Conquista outcrop areas, seepage of tailings fluids, and interformation leakage in downdip areas. Ground water within the Deweesville/Conquista aquifer immediately downgradient of the disposal cell discharges to the eastern tributary of Tordilla Creek, and might continue downdip into the subsurface where some ground water might discharge into Conquista Creek, southeast of FM 791. North of former tailings pile 3, ground water flows locally to the north toward Scared Dog Creek.

Seepage from tailings disposed of in old pits and on the outcrop of the Deweesville Sandstone and upper and middle Conquista subunits has resulted in a ground water mound in the Deweesville/Conquista aquifer. The Deweesville/Conquista potentiometric surface beneath tailings piles 1, 2, 4, and 5 is higher than background ground water levels. Ground water levels near the tailings have risen since initial mining. Before milling and tailings disposal activities, there was little water in the Deweesville/Conquista from the tailings area down to the tributary of Tordilla Creek (BEG, 1992). A review of the scientific literature on this site suggests this zone of the Deweesville/Conquista might have contained very little water prior to milling activity. The floor of open pit mine 5 (former tailings pile 5 ) extended several feet below the Deweesville/Conquista interface and a 1960 photograph of this pit in Bunker and MacKallor (1973) shows the contact between the Deweesville and the Conquista was dry. After these pits were filled with saturated tailings and later 
leachate injection/in situ leaching began, large volumes of tailings pore water were introduced to the Deweesville/Conquista. Consequently, a ground water mound developed on the processing site in and around the tailings piles. Currently, the water table in the outcrop area of the Deweesville is 8 to $17 \mathrm{ft}$ $(2$ to $5 \mathrm{~m}$ ) above the base of the Deweesville. The Conquista Clay also was affected by these milling-related processes and water levels beneath pile 7 (on the Conquista outcrop) may have been as much as $40 \mathrm{ft}(10 \mathrm{~m})$ higher than the background water table elevation (BEG, 1992). Background ground water conditions do not exist in the outcrop area of the Deweesville Sandstone immediately east of the site. Naturally occurring ground water might only exist where the Deweesville/Conquista aquifer dips below the Dubose (BEG, 1992). As shown on the map of the potentiometric surface contours developed from water levels measured in 1993 (Figure 3.6), ground water from the tailings flows in three directions: east away from former tailings pile 2, south toward the eastern tributary of Tordilla Creek, and southeast down the structural dip of the Deweesville beneath FM 791 and into the deeper subsurface.

\section{Dilworth aquifer}

5. - The Dilworth aquifer is a sandstone Member of the Whitsett Formation. It is separated from the Deweesville/Conquista aquifer by 30 to $50 \mathrm{ft}(9$ to $15 \mathrm{~m})$ of carbonaceous clay of the lower Conquista Clay subunit, which acts as an aquitard to downward seepage. The Dilworth aquifer extends approximately $100 \mathrm{ft}(30 \mathrm{~m})$ below the disposal cell.

Near the outcrop of the Dilworth sandstone (Figure 3.4), ground water is unconfined. Depths to ground water in the Dilworth aquifer range from approximately 30 to $100 \mathrm{ft}(9$ to $30 \mathrm{~m})$ below land surface. Downdip to the southeast, ground water in the Dilworth aquifer becomes confined by the lower Conquista clay. A cross sectional view of the potentiometric surface of the Dilworth aquifer is shown on Figure 3.5 .

A downward hydraulic gradient occurs between the Dilworth aquifer and the overlying Deweesville/Conquista aquifer. The potentiometric surface in the lower Dilworth aquifer shows ground water flows generally southeast beneath the site from the Dilworth outcrop (recharge area) northwest of the site. Thus, ground water from the Deweesville/Conquista aquifer could recharge the Dilworth aquifer. The Texas Bureau of Economic Geology identified three discrete potentiometric highs as an indication of leakage from the Deweesville/Conquista aquifer into the Dilworth aquifer. These leakages were caused by extensive deep drilling by mining companies exploring for ore. The potentiometric highs are near monitor wells 901,915 and 917 , and 905 and 907. The mining exploration programs drilled approximately 370 boreholes that typically penetrated through the Dilworth and were not abandoned properly (BEG, 1992). The monitor wells were constructed with the filter pack interval placed across the Conquista/Dilworth contact. The elevated water levels might be influenced by drainage from the Deweesville/Conquista aquifer through the well bore annulus rather than drainage through the formations. The Dilworth is 


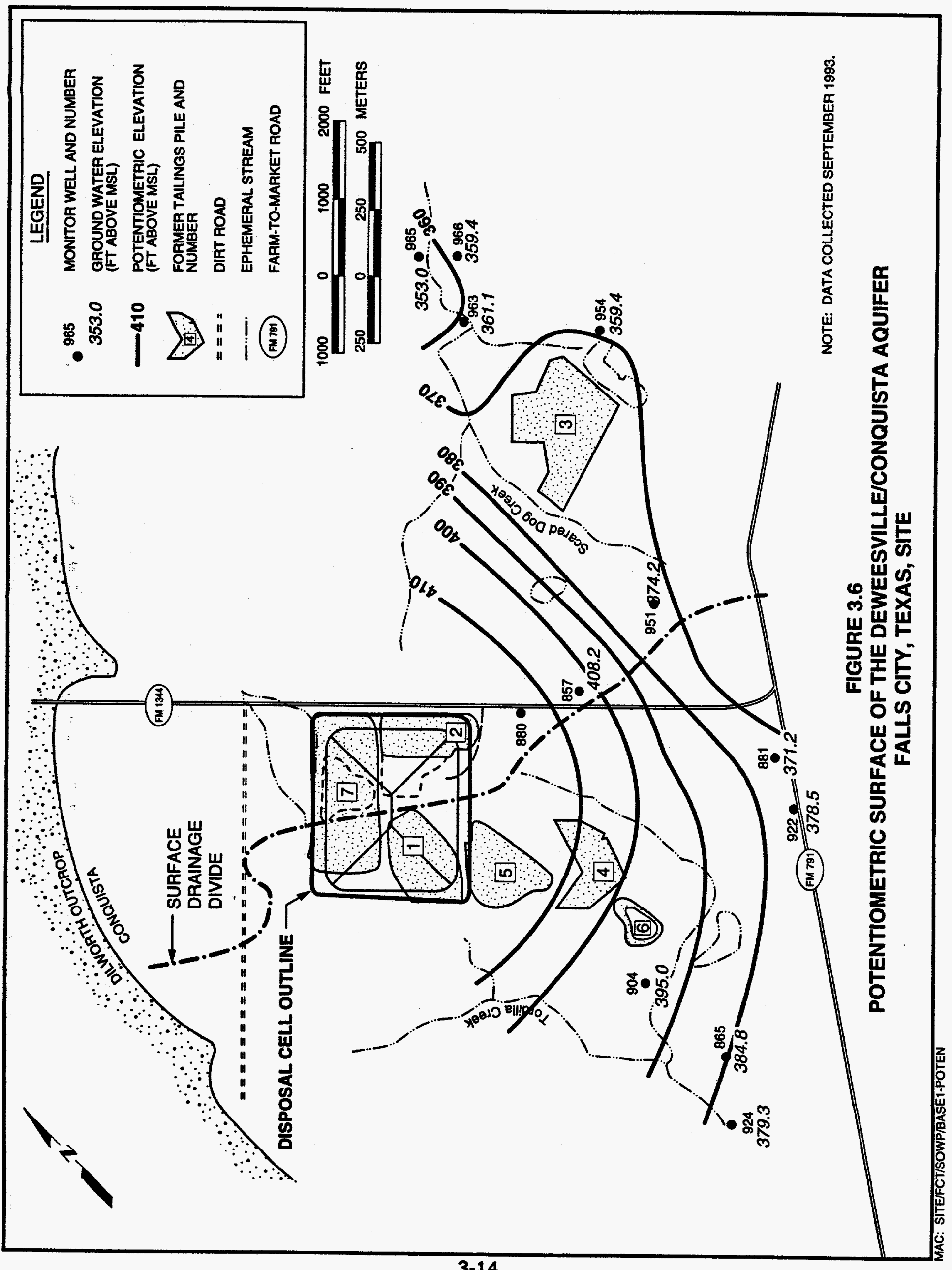


underlain by the carbonaceous clays and lignite seams of the Manning Clay Formation, which effectively form a $300-\mathrm{ft}(90-\mathrm{m})$-thick aquitard.

Because there is a potential hydraulic interconnection between the Deweesville/Conquista aquifer and the Dilworth unit by improperly abandoned exploratory boreholes, the Dilworth unit is included as part of the uppermost aquifer.

\section{Hydraulic and transport properties}

The saturated hydraulic conductivities of the most permeable beds of the Whitsett Formation aquifer system, as determined by aquifer tests and single-packer pressure testing, range from approximately 0.5 to $2.6 \mathrm{ft}$ per day (1.8 $\times 10^{-4}$ to $9.0 \times 10^{-4}$ centimeters per second $\left.[\mathrm{cm} / \mathrm{s}]\right)$. The TAC conducted this aquifer test and all other aquifer tests discussed here in the spring of 1991. The hydraulic conductivities are consistent with the ranges generally reported in the hydrologic literature for sandy clays, silty to clayey sands, and fine sandstones. The sandy members contain a high percentage of silts and clays, and yield small amounts of water (1 to 2 gallons [4 to 8 liters] per minute) to extraction wells. The lowest hydraulic conductivities are found in the carbonaceous clays of the lower Conquista Clay unit and the silty to clayey sands of the upper Dilworth Sandstone unit. The most permeable intervals tested are the fossiliferous sands of the middle Conquista Clay Member and the unconsolidated, fine-to-medium sands of the lower Dilworth Sandstone.

The horizontal hydraulic conductivities in the Deweesville and Conquista units are highly variable, with a value range of 2 orders of magnitude. The maximum horizontal hydraulic conductivity for the Deweesville/Conquista aquifer was $2.6 \mathrm{ft}$ per day $\left(9.0 \times 10^{-4} \mathrm{~cm} / \mathrm{s}\right)$ and was calculated from aquifer test data from a well screened in the Conquista Sandstone (DOE, 1992b). Using Darcy's Law, an assumed effective porosity of 0.1 , and an average hydraulic gradient of 0.013 to the east-southeast, the maximum average linear ground water velocity is $130 \mathrm{ft}(40 \mathrm{~m})$ per year.

Average linear ground water velocities in the Dilworth aquifer were calculated using a hydraulic conductivity of $0.68 \mathrm{ft}$ per day $\left(2.4 \times 10^{-4} \mathrm{~cm} / \mathrm{s}\right.$ ) (approximate maximum value from aquifer test), a hydraulic gradient of 0.009 to the eastsoutheast, and an assumed effective porosity of 0.1 for the fine sands of this zone (DOE, 1992b). The average linear velocity for ground water flow in the lower Dilworth aquifer is approximately $22 \mathrm{ft}(6.7 \mathrm{~m})$ per year.

A downward hydraulic potential flow exists between the Deweesville/Conquista and Dilworth aquifers. During a 10-hour aquifer test of monitor well 902 , completed in the Dilworth, drawdown was observed in an adjacent monitor well (676) screened in the Deweesville. Vertical leakage was calculated to be $7.4 \times$ $10^{-5}$ day $^{-1}$ from the analysis of time-drawdown data. Considering an aquitard thickness of $60 \mathrm{ft}(20 \mathrm{~m})$, the vertical hydraulic conductivity is $4.4 \times 10^{-3} \mathrm{ft}$ per day $\left(1.6 \times 10^{-6} \mathrm{~cm} / \mathrm{s}\right)$. 


\subsubsection{Background ground water quality}

Background ground water quality for the Deweesville/Conquista and Dilworth equifers is defined as the quality of ground water at the Falls City UMTRA site that would be present if uranium processing activities had not occurred.

There is no single background ground water quality for each of these aquifers. The natural ground water quality varies within these aquifers as a function of residence time and aquifer matrix composition. The Deweesville/Conquista and Dilworth aquifers can each be separated into three general regions or zones with different mineralogical and compositional characteristics. These zones are defined as the oxidized, transitional, and reduced zones. Although these zones overlap, the ground water in each zone typically is distinct in composition from the ground water in the other zones. Table 3.1 summarizes the range of background ground water quality at the site. The constituents and concentrations presented in Table 3.1 are based on the latest available data. Other background water quality data are presented in the Falls City RAP (DOE, 1992b). The numerous unmined and mined ore bodies in the oxidizing, transitional, and reducing zones of the regional sediments, cause considerable variation in the concentrations of hazardous trace constituents from zone to zone.

\section{Deweesville/Conquista}

The oxidized zone of the Deweesville/Conquista is defined as the outcrop area and shallow subsurface. At the Falls City UMTRA site, this zone was largely unsaturated before mining and milling. The oxidized zone later became saturated by the influx of large volumes of tailings leachate and mill processing water. Thus, ground water in this zone at the mill site is not the result of natural processes. Therefore, a background ground water quality for the oxidized, outcrop zone of the Deweesville/Conquista aquifer does not exist in the mill site area.

The transitional zone begins at the downdip edge of the Deweesville/Conquista outcrop (where the sediments are dominantly oxidized) and ends before the downgradient limit of the DOE monitor well array (e.g., 922 and 881 , where the sediments are dominantly reduced). Ground water quality before mining and milling activities in the uranium mineralized zone might have varied from conditions found in monitor well 951 to the much poorer quality ground water found in monitor well 922 . The interaction of oxidizing water from the recharge area with the pyrite- and ore-bearing sediments causes high variability in the background ground water in the transitional zone.

The upgradient limit of the reduced zone for the Deweesville/Conquista is defined by the DOE and Texas Bureau of Economic Geology as the downgradient edge of the DOE monitor well array (beginning at FM 791). Ground water quality data from Conoco monitor wells 667 and 668 suggest the ground water quality of the Deweesville/Conquista in parts of this zone is lower 
Table 3.1 Typical water quality data for Dilworth and Deweesville/Conquista background wells

\begin{tabular}{|c|c|c|c|c|c|c|c|c|}
\hline \multirow[b]{2}{*}{ Constituents } & \multirow{2}{*}{$\frac{\begin{array}{c}\text { Tailings } \\
\text { fluid }\end{array}}{607}$} & \multicolumn{2}{|c|}{ Reduced zone } & \multicolumn{2}{|c|}{ Transitional zone } & \multicolumn{3}{|c|}{ Oxidized zone loutcrop areal } \\
\hline & & 667 & 668 & 951 & 969 & 967 & 968 & 979 \\
\hline Alkalinity ${ }^{\mathbf{b}}$ & 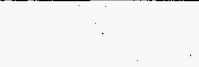 & 252 & 250 & 307 & 291 & 116 & 226 & 193 \\
\hline Calcium & 494 & 335 & 405 & 364 & 495 & 278 & 90 & 258 \\
\hline Chloride & 1210 & 785 & 944 & 708 & 779 & 793 & 338 & 672 \\
\hline Iron & 430 & 0.45 & 0.19 & 0.03 & 0.87 & $<0.03$ & $<0.03$ & $<0.03$ \\
\hline Magnesium & 185 & 31.8 & 45.1 & 29 & 61 & 30.5 & 8.1 & 28.3 \\
\hline Manganese & 21.8 & 0.21 & 0.78 & 0.21 & 2.94 & 0.02 & $<0.01$ & 0.07 \\
\hline Nitrate & 0.5 & 4.9 & 3.5 & 4 & 1.3 & 10.2 & 12.4 & 4.4 \\
\hline pH & 2.95 & 6.65 & 6.63 & 6.75 & 6.70 & 5.98 & 6.58 & 6.08 \\
\hline Potassium & 1.77 & 43 & 29 & 45 & 43 & 30 & 18 & 36 \\
\hline Sodium & 739 & 678 & 583 & 652 & 550 & 675 & 121 & 531 \\
\hline Sulfate & 7700 & 1043 & 930 & 856 & 1290 & 817 & 156 & 569 \\
\hline $\begin{array}{l}\text { Total dissolved } \\
\text { solids }\end{array}$ & 12900 & 3120 & 3310 & 2291 & 3650 & 2750 & 624 & 2210 \\
\hline Uranium & 1.19 & 0.015 & 0.017 & 0.008 & 0.010 & 0.003 & 0.068 & 0.25 \\
\hline
\end{tabular}

${ }^{a}$ Water quality data from January 1991.

${ }^{b} \mathrm{mg} / \mathrm{L} \mathrm{CaCO}_{3}$.

Note: 1. Water quality data from June 1991 and July 1991 from Dilworth background wells 967, 968, 969, and 979; and Deweesville/Conquista background wells 951, 667, and 668, except where noted.

2. Concentrations are reported in milligrams per liter except for $\mathrm{pH}$. 
in sulfate, chloride, and many other constituents than water from the transitional zone. Figure 3.7 shows the locations of the Conoco monitor wells (657 and 668) and Dilworth background monitor wells.

To improve the background water quality data base for the Deweesville/ Conquista, ground water quality data from other areas in the Deweesville/ Conquista were evaluated. Thirty-nine monitor wells were completed in the Deweesville Sandstone prior to mining activities at the Hobson in situ uranium mine site 8 or 9 mi (about $13 \mathrm{~km}$ ) east of the UMTRA site. Of these 39 wells, 28 were completed in the ore body and the remaining 11 were completed nearby. Table 3.2 presents a statistical summary of water quality data obtained from these Deweesville monitor wells.

The Deweesville wells at the Hobson site are generally screened between $\mathbf{3 0 0}$ to $450 \mathrm{ft}(90$ to $140 \mathrm{~m})$ below land surface. Therefore, ground water from the Hobson site probably has migrated farther into the reduced zone of this aquifer than ground water from monitor wells 667 and 668 . The greater residence time of contaminants in deeper ground water is reflected in the lower concentrations of sulfate, chloride, and other major and minor constituents in the Hobson ground water relative to the 600 series wells (Table 3.2). Nonetheless, the ground water from the 600 series wells and the Hobson wells might have followed a similar ground water quality evolutionary trend. Figure 3.8 shows a trilinear plot of wells 667 and 668 and the 11 Hobson wells drilled around the ore body.

Unlike the major and minor element data, the trace element data from the Hobson area ground water differ from those of monitor wells 667 and 668 . The Hobson data show significantly elevated levels of lead, radium-226, and uranium (Table 3.2), because most of the Hobson samples were Deweesville ground water that is equilibrating with uranium ore.

\section{Dilworth}

Four upgradient Dilworth monitor wells $(967,968,969$, and 979) are used to delineate the background water quality of this aquifer at the Falls City site. As shown on a trilinear plot (Figure 3.9), the upgradient Dilworth ground waters are not dominated by a single anionic species and contain subequal milliequivalents of sulfate and chloride with lesser bicarbonate. Sodium and calcium are the dominant cations. Table $\mathbf{3 . 3}$ presents a statistical summary of the water quality of the Dilworth background ground water.

Of the four DOE Dilworth background wells at the UMTRA site, three (967, 968, and 979) are completed in the oxidized zone, and one (969) is screened in the transitional zone of the aquifer. The ground water quality of monitor well 969 is more representative of the remaining Dilworth wells at the site. Although more data are needed to verify ambient ground water quality, the three upgradient wells in the oxidized zone of the Dilworth produce ground water of better quality than is probably typical of Dilworth ground water. 


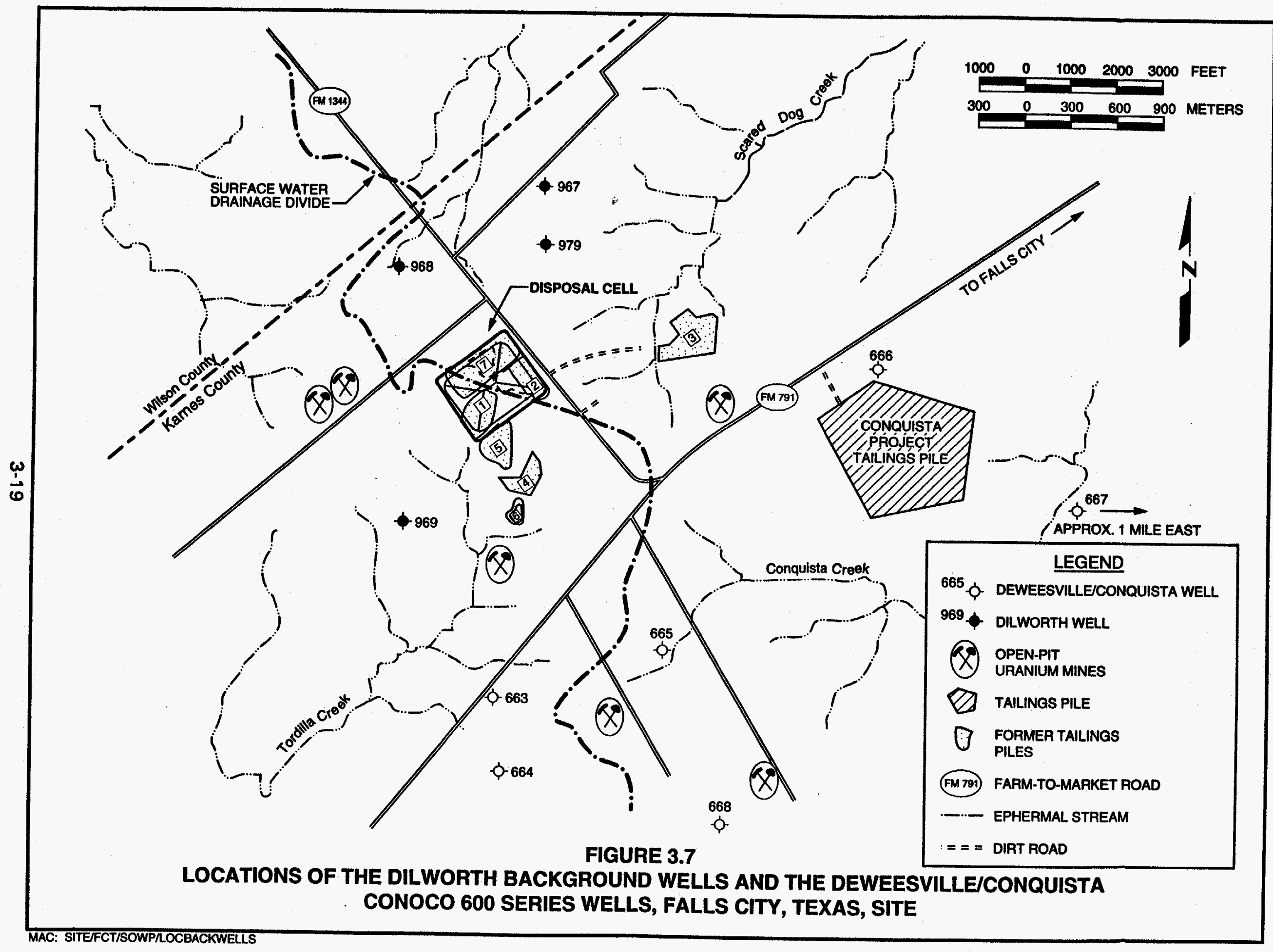




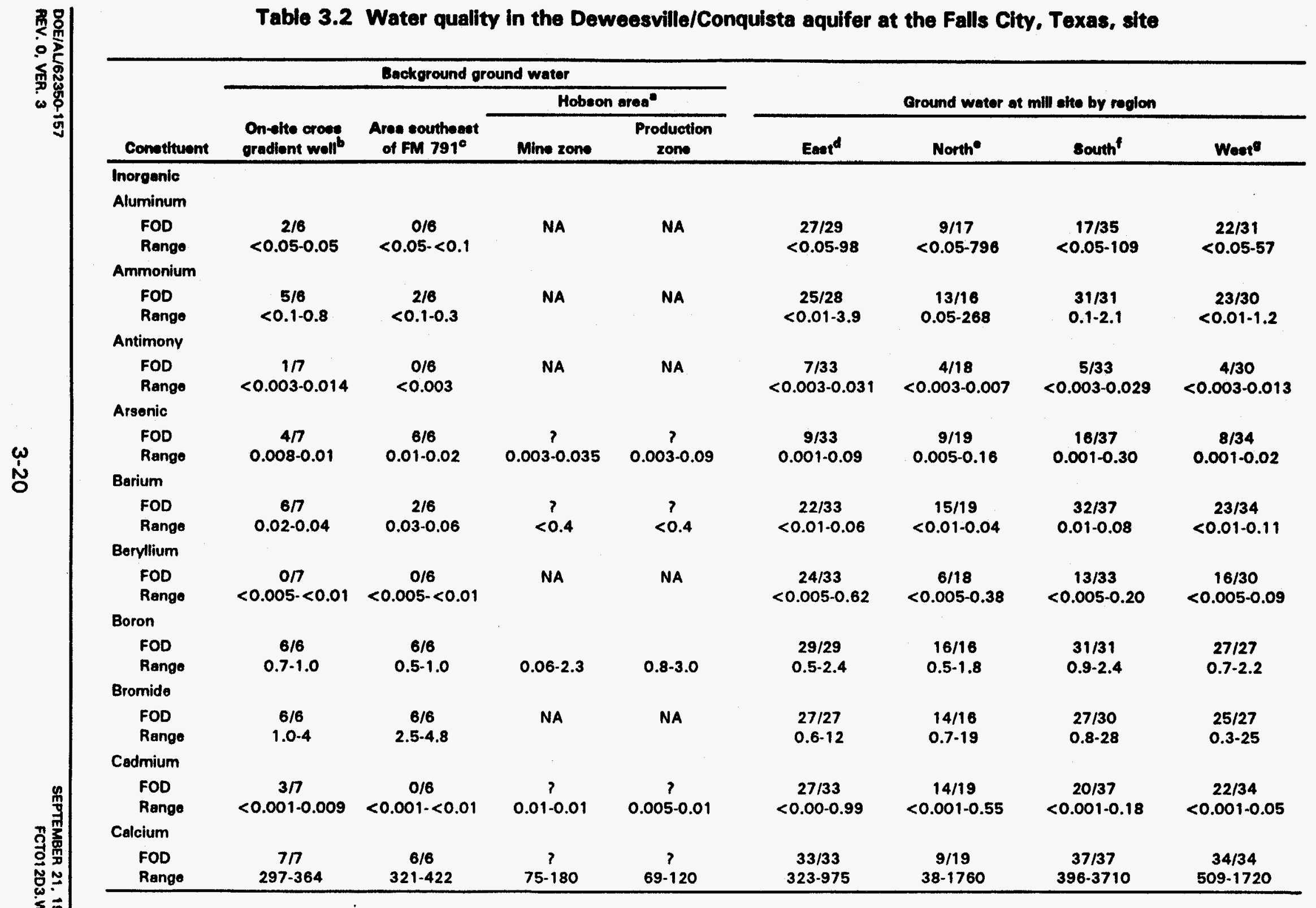




\begin{tabular}{|c|c|c|c|c|c|c|c|c|}
\hline \multirow[b]{3}{*}{ Conothuent } & \multirow[b]{3}{*}{$\begin{array}{l}\text { On-eite crows } \\
\text { grediont well }\end{array}$} & \multicolumn{3}{|c|}{ Background ground wator } & \multirow{2}{*}{\multicolumn{4}{|c|}{ Ground wator at mill alte by reglon }} \\
\hline & & & Hobse & rean & & & & \\
\hline & & $\begin{array}{l}\text { Area southeast } \\
\text { of FM } 791^{\circ}\end{array}$ & Mine zone & $\begin{array}{c}\text { Production } \\
\text { zone }\end{array}$ & Enet ${ }^{d}$ & North" & Bouth ${ }^{\prime}$ & Weat" \\
\hline \multicolumn{9}{|l|}{ Chloride } \\
\hline $\begin{array}{l}\text { FOD } \\
\text { Range }\end{array}$ & $\begin{array}{l}77 \\
708-780\end{array}$ & $\begin{array}{c}6 / 6 \\
785-1090\end{array}$ & $\begin{array}{c}7 \\
379-600\end{array}$ & $\stackrel{?}{264-542}$ & $\begin{array}{c}31 / 31 \\
621-2460\end{array}$ & $\begin{array}{c}19 / 19 \\
558-3800\end{array}$ & $\begin{array}{c}38 / 36 \\
680-7480\end{array}$ & $\begin{array}{c}34 / 34 \\
173-6820\end{array}$ \\
\hline \multicolumn{9}{|l|}{ Chromium } \\
\hline $\begin{array}{l}\text { FOD } \\
\text { Rango }\end{array}$ & $\begin{array}{c}177 \\
<0.01-0.01\end{array}$ & $\begin{array}{c}0 / 8 \\
<0.01\end{array}$ & $\begin{array}{c}? \\
<0.01-0.1\end{array}$ & $\begin{array}{c}? \\
<0.01-0.1\end{array}$ & $\begin{array}{c}3 / 33 \\
<0.01 \cdot 0.01\end{array}$ & $\begin{array}{c}5 / 19 \\
<0.01-0.03\end{array}$ & $\begin{array}{c}3 / 37 \\
<0.01-0.02\end{array}$ & $\begin{array}{c}4 / 34 \\
<0.01 \cdot 0.03\end{array}$ \\
\hline \multicolumn{9}{|l|}{ Cobalt } \\
\hline $\begin{array}{l}\text { FOD } \\
\text { Rango }\end{array}$ & $\begin{array}{c}1 / 7 \\
0.01\end{array}$ & $\begin{array}{c}0 / 6 \\
<0.03-<0.05\end{array}$ & NA & NA & $\begin{array}{c}31 / 33 \\
<0.03-1.2\end{array}$ & $\begin{array}{c}6 / 18 \\
0.01-0.7\end{array}$ & $\begin{array}{c}15 / 18 \\
0.01-0.6\end{array}$ & $\begin{array}{c}19 / 30 \\
0.01-0.3\end{array}$ \\
\hline \multicolumn{9}{|l|}{ Copper } \\
\hline $\begin{array}{l}\text { FOD } \\
\text { Range }\end{array}$ & $\begin{array}{c}177 \\
<0.01-0.03\end{array}$ & $\begin{array}{c}0 / 6 \\
<0.01-<0.02\end{array}$ & $\frac{?}{0.01-0.2}$ & $\begin{array}{c}? \\
<0.01-0.5\end{array}$ & $\begin{array}{c}13 / 33 \\
<0.01-0.25\end{array}$ & $\begin{array}{c}9 / 18 \\
<0.01-0.12\end{array}$ & $\begin{array}{c}14 / 33 \\
<0.01-0.07\end{array}$ & $\begin{array}{c}14 / 30 \\
<0.01-0.11\end{array}$ \\
\hline \multicolumn{9}{|l|}{ Cyanide } \\
\hline $\begin{array}{l}\text { FOD } \\
\text { Range }\end{array}$ & $\begin{array}{c}0 / 5 \\
<0.01-<0.02\end{array}$ & $\begin{array}{l}0 / 6 \\
<0.01\end{array}$ & NA & NA & $\begin{array}{c}1 / 24 \\
<0.01-0.01\end{array}$ & $\begin{array}{c}1 / 12 \\
<0.01-0.02\end{array}$ & $\begin{array}{c}0 / 18 \\
<0.01-<0.02\end{array}$ & $\begin{array}{c}2 / 19 \\
<0.01-0.02\end{array}$ \\
\hline \multicolumn{9}{|l|}{ Fluoride } \\
\hline $\begin{array}{l}\text { FOD } \\
\text { Range }\end{array}$ & $\begin{array}{c}6 / 6 \\
0.2-0.8\end{array}$ & $\begin{array}{c}6 / 6 \\
0.6-0.7\end{array}$ & $\begin{array}{c}? \\
0.1-2\end{array}$ & $\begin{array}{c}? \\
0.04-0.4\end{array}$ & $\begin{array}{c}26 / 28 \\
<0.1-4.3\end{array}$ & $\begin{array}{c}15 / 16 \\
<0.1-43\end{array}$ & $\begin{array}{c}28 / 30 \\
<0.1-12\end{array}$ & $\begin{array}{l}24 / 27 \\
<0.1-4\end{array}$ \\
\hline \multicolumn{9}{|l|}{ Iron } \\
\hline $\begin{array}{l}\text { FOD } \\
\text { Renge }\end{array}$ & $\begin{array}{c}4 / 7 \\
0.02-0.06\end{array}$ & $\begin{array}{c}5 / 6 \\
<0.03-0.45\end{array}$ & $\stackrel{?}{0.06-2.3}$ & $\stackrel{?}{0.07-5.8}$ & $\begin{array}{c}29 / 33 \\
<0.03-126\end{array}$ & $\begin{array}{c}11 / 19 \\
0.02-458\end{array}$ & $\begin{array}{c}33 / 37 \\
0.02-49\end{array}$ & $\begin{array}{c}19 / 34 \\
0.02-77\end{array}$ \\
\hline \multicolumn{9}{|l|}{ Load } \\
\hline $\begin{array}{l}\text { FOD } \\
\text { Range }\end{array}$ & $\begin{array}{c}1 / 7 \\
0.001\end{array}$ & $\begin{array}{c}0 / 6 \\
<0.005-<0.01\end{array}$ & $\begin{array}{c}? \\
0.03-0.10\end{array}$ & $\begin{array}{c}? \\
0.02-0.15\end{array}$ & $\begin{array}{c}9 / 33 \\
0.001-0.04\end{array}$ & $\begin{array}{c}4 / 19 \\
0.001-0.02\end{array}$ & $\begin{array}{c}8 / 37 \\
<0.001 \cdot 0.03\end{array}$ & $\begin{array}{c}7 / 34 \\
0.001-0.02\end{array}$ \\
\hline \multicolumn{9}{|l|}{ Magnesium } \\
\hline $\begin{array}{l}\text { FOD } \\
\text { Range }\end{array}$ & $\begin{array}{c}717 \\
26-33\end{array}$ & $\begin{array}{c}6 / 6 \\
32-51\end{array}$ & $\begin{array}{l}? \\
0.3-9.4\end{array}$ & $\stackrel{?}{1.8-4.2}$ & $\begin{array}{c}33 / 33 \\
36-574\end{array}$ & $\begin{array}{c}19 / 19 \\
5-1050\end{array}$ & $\begin{array}{l}37 / 87 \\
44.752\end{array}$ & $\begin{array}{c}34 / 34 \\
81.381\end{array}$ \\
\hline \multicolumn{9}{|l|}{ Manganese } \\
\hline $\begin{array}{l}\text { FOD } \\
\text { Rango }\end{array}$ & $\begin{array}{c}7 / 7 \\
0.04-0.6\end{array}$ & $\begin{array}{c}6 / 6 \\
0.2-0.8\end{array}$ & $\begin{array}{l}? \\
0.1-0.4\end{array}$ & $\stackrel{?}{0.03-0.3}$ & $\begin{array}{c}32 / 33 \\
<0.01 .51\end{array}$ & $\begin{array}{c}19 / 19 \\
0.04-74\end{array}$ & $\begin{array}{c}37 / 37 \\
1.59-49\end{array}$ & $\begin{array}{c}34 / 34 \\
0.04-16\end{array}$ \\
\hline
\end{tabular}




\begin{tabular}{|c|c|c|c|c|c|c|c|c|}
\hline \multirow[b]{3}{*}{ Cometituent } & \multicolumn{4}{|c|}{ Background ground wator } & & & & \\
\hline & \multirow[b]{2}{*}{$\begin{array}{l}\text { On-ate oroas: } \\
\text { gradient woll }\end{array}$} & \multirow[b]{2}{*}{$\begin{array}{l}\text { Aren sourtheaset } \\
\text { of FM } 791^{\circ}\end{array}$} & \multicolumn{2}{|c|}{ Hobson ares" } & \multicolumn{4}{|c|}{ Ground water at mill alte by roglon } \\
\hline & & & Mine zone & $\begin{array}{c}\text { Production } \\
\text { zone }\end{array}$ & Eand & Northe & south' & Weat" \\
\hline \multicolumn{9}{|l|}{ Morcury } \\
\hline $\begin{array}{l}\text { FoD } \\
\text { Range }\end{array}$ & $\begin{array}{c}0 / 6 \\
<0.0002\end{array}$ & $\begin{array}{c}0 / 6 \\
<0.0002\end{array}$ & $\begin{array}{c}? \\
<0.001-0.001\end{array}$ & $\begin{array}{l}? \\
<0.001\end{array}$ & $\begin{array}{c}3 / 29 \\
<0.0002-0.002\end{array}$ & $\begin{array}{c}1 / 15 \\
<0.0002-0.001\end{array}$ & $\begin{array}{c}1 / 30 \\
<0.0002-0.0002\end{array}$ & $\begin{array}{c}4 / 28 \\
<0.0002-0.009\end{array}$ \\
\hline \multicolumn{9}{|l|}{ Molybdonum } \\
\hline $\begin{array}{l}\text { FOD } \\
\text { Range }\end{array}$ & $\begin{array}{c}3 / 7 \\
<0.01-0.02\end{array}$ & $\begin{array}{c}4 / 6 \\
<0.01-0.02\end{array}$ & $\begin{array}{c}? \\
<0.1-0.1\end{array}$ & $\begin{array}{c}? \\
<0.1-0.2\end{array}$ & $\begin{array}{c}3 / 33 \\
<0.01-0.02\end{array}$ & $\begin{array}{c}10 / 19 \\
<0.01-0.09\end{array}$ & $\begin{array}{c}15 / 37 \\
<0.01-0.68\end{array}$ & $\begin{array}{c}11 / 34 \\
<0.01-0.18\end{array}$ \\
\hline \multicolumn{9}{|l|}{ Nickol } \\
\hline $\begin{array}{l}\text { FOD } \\
\text { Range }\end{array}$ & $\begin{array}{c}2 \pi \\
0.01-0.1\end{array}$ & $\begin{array}{c}0 / 6 \\
<0.04\end{array}$ & $\begin{array}{c}? \\
<0.02-0.2\end{array}$ & $\begin{array}{c}? \\
<0.01-0.08\end{array}$ & $\begin{array}{c}29 / 33 \\
0.03-1.3\end{array}$ & $\begin{array}{c}8 / 19 \\
0.01-0.9\end{array}$ & $\begin{array}{c}18 / 37 \\
0.01-1.0\end{array}$ & $\begin{array}{c}22134 \\
0.01-0.3\end{array}$ \\
\hline \multicolumn{9}{|l|}{ Nitrate } \\
\hline $\begin{array}{l}\text { FOD } \\
\text { Range }\end{array}$ & $\begin{array}{c}47 \\
<0.1-4\end{array}$ & $\begin{array}{c}2 / 6 \\
<1.0-4.9\end{array}$ & $\stackrel{?}{1-4}$ & $\begin{array}{c}? \\
2-9\end{array}$ & $\begin{array}{l}27 / 32 \\
0.3 \cdot 15\end{array}$ & $\begin{array}{c}15 / 18 \\
<1.0-53\end{array}$ & $\begin{array}{c}28 / 33 \\
<1.0-62\end{array}$ & $\begin{array}{l}25 / 32 \\
0.7-18\end{array}$ \\
\hline \multicolumn{9}{|l|}{ Phosphate } \\
\hline $\begin{array}{l}\text { FOD } \\
\text { Range }\end{array}$ & $\begin{array}{c}5 / 6 \\
0.1 \cdot 0.3\end{array}$ & $\begin{array}{c}2 / 6 \\
<0.1-0.1\end{array}$ & NA & NA & $\begin{array}{c}22 / 28 \\
<0.1-1.1\end{array}$ & $\begin{array}{l}13 / 15 \\
0.1-14\end{array}$ & $\begin{array}{c}19 / 26 \\
<0.1-2.0\end{array}$ & $\begin{array}{c}20 / 25 \\
<0.1-1.6\end{array}$ \\
\hline \multicolumn{9}{|l|}{ Potassium } \\
\hline $\begin{array}{l}\text { FOD } \\
\text { Range }\end{array}$ & $\begin{array}{c}77 \\
38-46\end{array}$ & $\begin{array}{c}6 / 6 \\
29-44\end{array}$ & $\stackrel{?}{31-51}$ & $\stackrel{?}{30-45}$ & $\begin{array}{l}33 / 33 \\
21.94\end{array}$ & $\begin{array}{l}19 / 19 \\
6 \cdot 287\end{array}$ & $\begin{array}{c}37 / 37 \\
47.505\end{array}$ & $\begin{array}{c}34 / 34 \\
45-114\end{array}$ \\
\hline \multicolumn{9}{|l|}{ Selenium } \\
\hline $\begin{array}{l}\text { FOD } \\
\text { Range }\end{array}$ & $\begin{array}{c}2 / 7 \\
0.002-0.012\end{array}$ & $\begin{array}{c}0 / 6 \\
<0.005\end{array}$ & $\begin{array}{c}? \\
0.004-0.05\end{array}$ & $\stackrel{?}{?} 0.003 \cdot 0.06$ & $\begin{array}{c}19 / 33 \\
0.002-0.60\end{array}$ & $\begin{array}{c}11 / 19 \\
<0.005-0.22\end{array}$ & $\begin{array}{c}17 / 37 \\
0.002-1.2\end{array}$ & $\begin{array}{c}20 / 34 \\
0.002-1.2\end{array}$ \\
\hline \multicolumn{9}{|l|}{ Silica } \\
\hline $\begin{array}{l}\text { FOD } \\
\text { Range }\end{array}$ & $\begin{array}{c}6 / 6 \\
43-49\end{array}$ & $\begin{array}{c}6 / 6 \\
34-49\end{array}$ & $\stackrel{?}{53.76}$ & $\stackrel{?}{55 \cdot 103}$ & $\begin{array}{c}29 / 29 \\
11.165\end{array}$ & $\begin{array}{r}17 / 17 \\
43-171\end{array}$ & $\begin{array}{c}34 / 34 \\
22-141\end{array}$ & $\begin{array}{c}31 / 31 \\
42-198\end{array}$ \\
\hline \multicolumn{9}{|l|}{ Silver } \\
\hline $\begin{array}{c}\text { FOD } \\
\text { Renge } \\
\text { Sodium }\end{array}$ & $\begin{array}{c}0 / 7 \\
<0.01\end{array}$ & $\begin{array}{c}0 / 6 \\
<0.01\end{array}$ & $\begin{array}{c}? \\
<0.01 \cdot 0.02\end{array}$ & $\begin{array}{c}? \\
<0.01-0.09\end{array}$ & $\begin{array}{c}2 / 33 \\
<0.01 \cdot 0.08\end{array}$ & $\begin{array}{c}1 / 18 \\
<0.01-0.07\end{array}$ & $\begin{array}{c}1 / 33 \\
<0.01-0.01\end{array}$ & $\begin{array}{c}1 / 30 \\
<0.01-0.01\end{array}$ \\
\hline $\begin{array}{l}\text { FOD } \\
\text { Range }\end{array}$ & $\begin{array}{c}717 \\
530-652\end{array}$ & $\begin{array}{c}8 / 6 \\
560-678\end{array}$ & $\stackrel{?}{313-564}$ & $\begin{array}{c}? \\
248-399\end{array}$ & $\begin{array}{c}33 / 33 \\
383 \cdot 1560\end{array}$ & $\begin{array}{c}19 / 19 \\
90-2870\end{array}$ & $\begin{array}{c}37 / 37 \\
606-3540\end{array}$ & $\begin{array}{c}34 / 34 \\
742-2310\end{array}$ \\
\hline
\end{tabular}




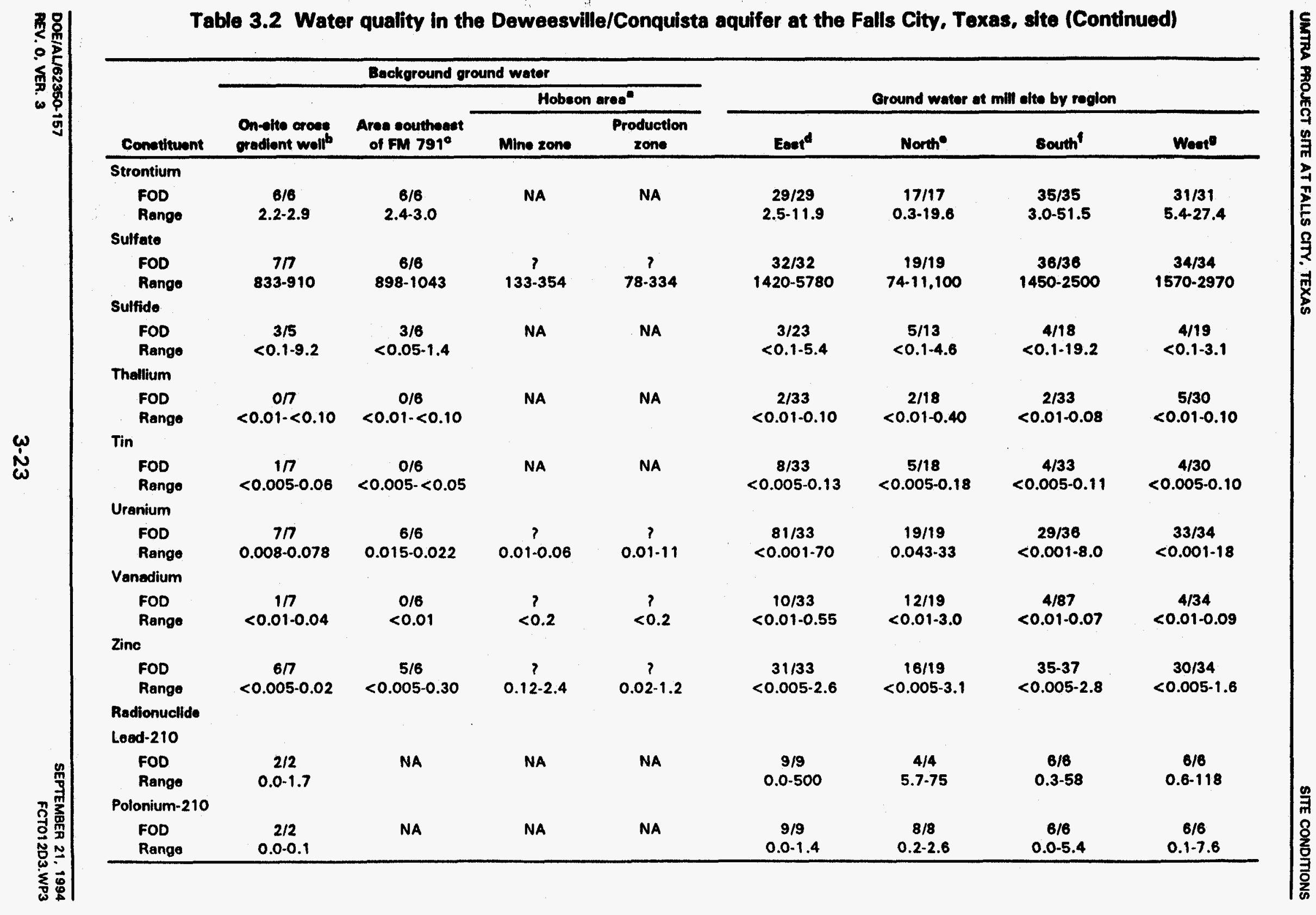



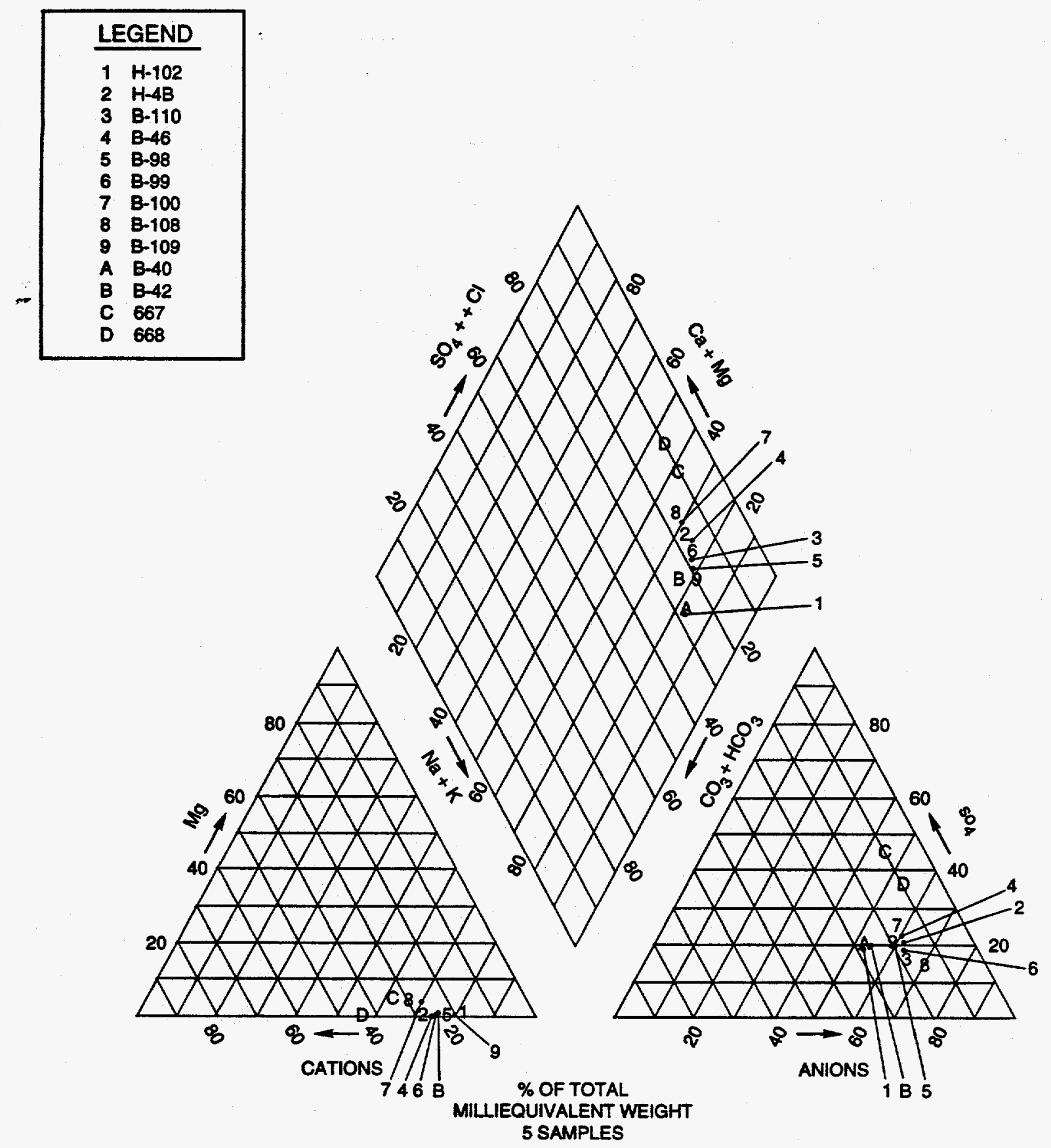

FIGURE 3.8

TRILINEAR PLOT OF DATA FROM DEWEESVILLE/CONQUISTA MONITOR WELLS 667,668 , AND SELECTED HOBSON MONITOR WELLS

FALLS CITY, TEXAS, SITE 

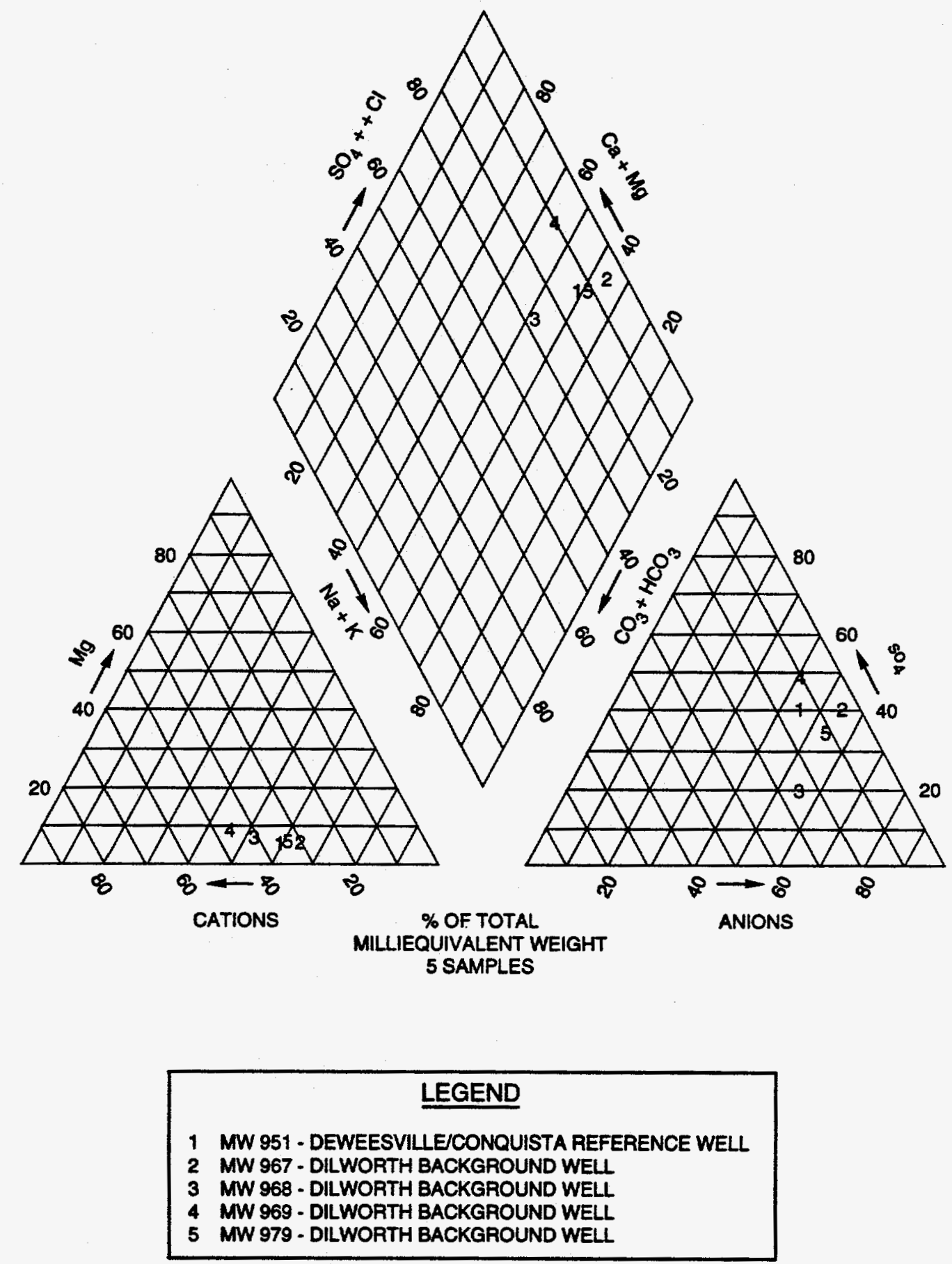

FIGURE 3.9

TRILINEAR PLOT OF DILWORTH BACKGROUND GROUND WATER AND DEWEESVILLE/CONQUISTA REFERENCE WATER FALLS CITY, TEXAS, SITE 
Table 3.3 Statistical summary of the Dilworth ground water quality at the Falls City, Texas, site

\begin{tabular}{|c|c|c|c|c|}
\hline \multirow[b]{3}{*}{ Constituent } & \multirow{3}{*}{$\begin{array}{l}\text { Frequency of } \\
\text { detection }\end{array}$} & \multicolumn{3}{|c|}{ Observed concentration } \\
\hline & & Minimum & Mediana & Maximum \\
\hline & & $(\mathrm{mg} / \mathrm{L})$ & $(\mathrm{mg} / \mathrm{L})$ & (mg/L) \\
\hline \multicolumn{5}{|l|}{ Chemical } \\
\hline \multicolumn{5}{|l|}{ Aluminum } \\
\hline Background ${ }^{b}$ & $2 / 18$ & $<0.05$ & c & 0.05 \\
\hline $833^{c}$ & $1 / 1$ & d & 0.71 & $d$ \\
\hline $977^{\circ}$ & $4 / 4$ & 0.45 & 0.71 & 1.02 \\
\hline \multicolumn{5}{|l|}{ Ammonium } \\
\hline Background ${ }^{b}$ & $12 / 18$ & $<0.1$ & 0.1 & 2.0 \\
\hline $833^{b}$ & $1 / 1$ & $d$ & 5.7 & d \\
\hline $977^{c}$ & $3 / 4$ & $<0.1$ & 0.2 & 0.9 \\
\hline \multicolumn{5}{|l|}{ Antimony } \\
\hline Background & $2 / 22$ & $<0.003$ & $d$ & 0.008 \\
\hline 833 & $0 / 1$ & d & $d$ & d \\
\hline 977 & $1 / 5$ & $<0.003$ & $d$ & 0.004 \\
\hline \multicolumn{5}{|l|}{ Arsenic } \\
\hline $\begin{array}{l}\text { Background } \\
\text { (969) }\end{array}$ & $6 / 6$ & 0.10 & 0.28 & 0.39 \\
\hline 833 & $1 / 1$ & $d$ & 0.05 & d \\
\hline 977 & $0 / 5$ & $d$ & d & d \\
\hline \multicolumn{5}{|l|}{ Barium } \\
\hline $\begin{array}{l}\text { Background } \\
\text { (969) }\end{array}$ & $6 / 6$ & 0.04 & 0.05 & 0.10 \\
\hline 833 & $1 / 1$ & d & 0.03 & d \\
\hline 977 & $4 / 5$ & 0.01 & $0.01-0.02$ & 0.02 \\
\hline \multicolumn{5}{|l|}{ Beryllium } \\
\hline Background ${ }^{b}$ & $0 / 22$ & d & d & $d$ \\
\hline $833^{C}$ & $0 / 1$ & $d$ & $d$ & d \\
\hline $977^{e}$ & $1 / 5$ & $<0.005$ & d & 0.005 \\
\hline
\end{tabular}


Table 3.3 Statistical summary of the Dilworth ground water quality at the Falls City, Texas, site (Continued)

\begin{tabular}{|c|c|c|c|c|}
\hline \multirow[b]{3}{*}{ Constituent } & \multirow{3}{*}{$\begin{array}{c}\text { Frequency of } \\
\text { detection }\end{array}$} & \multicolumn{3}{|c|}{ Observed concentration } \\
\hline & & Minimum & Median ${ }^{a}$ & Maximum \\
\hline & & $(\mathrm{mg} / \mathrm{L})$ & $(\mathrm{mg} / \mathrm{L})$ & $(\mathrm{mg} / \mathrm{L})$ \\
\hline \multicolumn{5}{|l|}{ Boron } \\
\hline $\begin{array}{l}\text { Background } \\
(967)\end{array}$ & $4 / 4$ & 0.88 & 1.03 & 1.10 \\
\hline 833 & $1 / 1$ & d & 0.85 & d \\
\hline 977 & $4 / 4$ & 0.72 & 0.83 & 0.98 \\
\hline \multicolumn{5}{|l|}{ Bromide } \\
\hline $\begin{array}{l}\text { Background } \\
\text { (969) }\end{array}$ & $5 / 5$ & 2.6 & 3.2 & 5.8 \\
\hline 833 & $1 / 1$ & d & 1.0 & d \\
\hline 977 & $4 / 4$ & 1.7 & 1.8 & 2.1 \\
\hline \multicolumn{5}{|l|}{ Cadmium } \\
\hline Background & $6 / 22$ & $<0.001$ & d & 0.005 \\
\hline 833 & $0 / 1$ & d & $d$ & d \\
\hline 977 & $5 / 5$ & 0.013 & 0.020 & 0.022 \\
\hline \multicolumn{5}{|l|}{ Calcium } \\
\hline $\begin{array}{l}\text { Background } \\
\text { (969) }\end{array}$ & $6 / 6$ & 481 & 502 & 560 \\
\hline 833 & $1 / 1$ & d & 367 & d \\
\hline 977 & $5 / 5$ & 188 & 242 & 282 \\
\hline \multicolumn{5}{|l|}{ Chloride } \\
\hline $\begin{array}{l}\text { Background } \\
(967,969)\end{array}$ & $11 / 11$ & 680 & 793 & 1020 \\
\hline $833^{C}$ & $1 / 1$ & d & 472 & $d$ \\
\hline $977^{\circ}$ & $5 / 5$ & 280 & 374 & 553 \\
\hline \multicolumn{5}{|l|}{ Chromium } \\
\hline Background & $4 / 22$ & $<0.01$ & d & 0.02 \\
\hline 833 & $0 / 1$ & $d$ & d & d \\
\hline 977 & $1 / 5$ & $<0.01$ & $d$ & 0.01 \\
\hline \multicolumn{5}{|l|}{ Cobalt } \\
\hline Background & $3 / 22$ & 0.01 & d & 0.05 \\
\hline 833 & $1 / 1$ & d & 0.08 & $d$ \\
\hline 977 & $5 / 5$ & 0.06 & 0.08 & 0.09 \\
\hline
\end{tabular}


Table 3.3 Statistical summary of the Dilworth ground water quality at the Falls City, Texas, site (Continued)

\begin{tabular}{|c|c|c|c|c|}
\hline \multirow[b]{3}{*}{ Constituent } & \multirow{3}{*}{$\begin{array}{c}\text { Frequency of } \\
\text { detection }\end{array}$} & \multicolumn{3}{|c|}{ Observed concentration } \\
\hline & & Minimum & Median $^{\mathbf{a}}$ & Maximum \\
\hline & & $(\mathrm{mg} / \mathrm{L})$ & $(\mathrm{mg} / \mathrm{L})$ & $(\mathrm{mg} / \mathrm{L})$ \\
\hline \multicolumn{5}{|l|}{ Copper } \\
\hline Background & $4 / 22$ & $<0.01$ & d & 0.06 \\
\hline 833 & $0 / 1$ & d & d & d \\
\hline 977 & $2 / 5$ & $<0.01$ & d & 0.03 \\
\hline \multicolumn{5}{|l|}{ Cyanide } \\
\hline Background & $2 / 20$ & $<0.01$ & $d$ & 0.02 \\
\hline 833 & d & $d$ & d & d \\
\hline 977 & $1 / 5$ & $<0.01$ & d & 0.01 \\
\hline \multicolumn{5}{|l|}{ Fluoride } \\
\hline $\begin{array}{l}\text { Background } \\
(979)\end{array}$ & $5 / 5$ & 0.4 & 0.4 & 0.5 \\
\hline $833^{C}$ & $1 / 1$ & d & 1.0 & d \\
\hline $977^{e}$ & $1 / 4$ & $<0.1$ & $d$ & 0.2 \\
\hline \multicolumn{5}{|l|}{ Iron } \\
\hline $\begin{array}{l}\text { Background } \\
(969)\end{array}$ & $6 / 6$ & 0.24 & 0.78 & 2.70 \\
\hline 833 & $1 / 1$ & d & 127 & d \\
\hline 977 & $5 / 5$ & 0.14 & 0.53 & 1.43 \\
\hline \multicolumn{5}{|l|}{ Lead } \\
\hline Background & $2 / 22$ & 0.001 & d & 0.002 \\
\hline 833 & $0 / 1$ & d & $d$ & d \\
\hline 977 & $0 / 5$ & d & $d$ & $d$ \\
\hline \multicolumn{5}{|l|}{ Magnesium } \\
\hline $\begin{array}{l}\text { Background } \\
(969)\end{array}$ & $6 / 6$ & 54 & 57 & 65 \\
\hline 833 & $1 / 1$ & d & 67 & d \\
\hline 977 & $5 / 5$ & 20 & 27 & 33 \\
\hline \multicolumn{5}{|l|}{ Manganese } \\
\hline $\begin{array}{l}\text { Background } \\
\text { (969) }\end{array}$ & $6 / 6$ & 2.8 & 3.2 & 3.7 \\
\hline 833 & $1 / 1$ & d & 3.3 & d \\
\hline 977 & $5 / 5$ & 1.4 & 1.7 & 2.4 \\
\hline
\end{tabular}


Table 3.3 Statistical summary of the Dilworth ground water quality at the Falls City. Texas, site (Continued)

\begin{tabular}{|c|c|c|c|c|}
\hline \multirow[b]{3}{*}{ Constituent } & \multirow{3}{*}{$\begin{array}{c}\text { Frequency of } \\
\text { detection }\end{array}$} & \multicolumn{3}{|c|}{ Observed concentration } \\
\hline & & Minimum & Median $^{\mathbf{a}}$ & Maximum \\
\hline & & (mg/L) & $(\mathrm{mg} / \mathrm{L})$ & $(\mathrm{mg} / \mathrm{L})$ \\
\hline \multicolumn{5}{|l|}{ Mercury } \\
\hline Background ${ }^{b}$ & $0 / 22$ & d & d & d \\
\hline $833^{C}$ & $0 / 1$ & d & d & $d$ \\
\hline $977^{e}$ & $0 / 5$ & d & $d$ & d \\
\hline \multicolumn{5}{|l|}{ Molybdenum } \\
\hline $\begin{array}{l}\text { Background } \\
(968,969)\end{array}$ & $11 / 11$ & 0.02 & 0.04 & 0.07 \\
\hline 833 & $1 / 1$ & $d$ & 0.02 & $d$ \\
\hline 977 & $1 / 5$ & $<0.01$ & $d$ & 0.01 \\
\hline \multicolumn{5}{|l|}{ Nickel } \\
\hline Background & $2 / 22$ & 0.01 & $d$ & 0.01 \\
\hline 833 & $1 / 1$ & $d$ & 0.09 & d \\
\hline 977 & $5 / 5$ & 0.07 & 0.10 & 0.11 \\
\hline \multicolumn{5}{|l|}{ Nitrate } \\
\hline Background & $16 / 22$ & $<1.0$ & 3.3 & 13.0 \\
\hline 833 & $1 / 1$ & d & 1.8 & $d$ \\
\hline 977 & $4 / 5$ & $<1.0$ & 3.1 & 6.4 \\
\hline \multicolumn{5}{|l|}{ Phosphate } \\
\hline Background & $16 / 18$ & 0.3 & 0.5 & 1.1 \\
\hline 833 & $1 / 1$ & d & 0.5 & d \\
\hline 977 & $3 / 4$ & $<0.1$ & 0.2 & 0.2 \\
\hline \multicolumn{5}{|l|}{ Potassium } \\
\hline $\begin{array}{l}\text { Background } \\
\text { (969) }\end{array}$ & $6 / 6$ & 37 & 42 & 44 \\
\hline $833^{c}$ & $1 / 1$ & d & 44 & d \\
\hline $977^{e}$ & $5 / 5$ & 24 & 30 & 37 \\
\hline \multicolumn{5}{|l|}{ Selenium } \\
\hline Background & $8 / 22$ & 0.002 & d & 0.024 \\
\hline 833 & $0 / 1$ & d & d & $d$ \\
\hline 977 & $1 / 5$ & $<0.005$ & d & 0.007 \\
\hline
\end{tabular}


Table 3.3 Statistical summary of the Dilworth ground water quality at the Falls City, Texas, site (Continued)

\begin{tabular}{|c|c|c|c|c|}
\hline \multirow[b]{3}{*}{ Constituent } & \multirow{3}{*}{$\begin{array}{c}\text { Frequency of } \\
\text { detection }\end{array}$} & \multicolumn{3}{|c|}{ Observed concentration } \\
\hline & & Minimum & Median $^{\mathbf{a}}$ & Maximum \\
\hline & & (mg/L) & (mg/L) & (mg/L) \\
\hline \multicolumn{5}{|l|}{ Silica } \\
\hline $\begin{array}{l}\text { Background } \\
\text { (968) }\end{array}$ & $4 / 4$ & 88 & 91 & 100 \\
\hline 833 & $1 / 1$ & d & 45 & d \\
\hline 977 & $4 / 4$ & 88 & 102 & 121 \\
\hline \multicolumn{5}{|l|}{ Silver } \\
\hline Background & $1 / 22$ & $<0.01$ & d & 0.02 \\
\hline 833 & $0 / 1$ & d & d & d \\
\hline 977 & $0 / 5$ & $d$ & d & $d$ \\
\hline \multicolumn{5}{|l|}{ Sodium } \\
\hline $\begin{array}{l}\text { Background } \\
(967,969)\end{array}$ & $11 / 11$ & 482 & 550 & 675 \\
\hline 833 & $1 / 1$ & d & 604 & d \\
\hline 977 & $5 / 5$ & 412 & 484 & 520 \\
\hline \multicolumn{5}{|l|}{ Strontium } \\
\hline $\begin{array}{l}\text { Background } \\
\text { (979) }\end{array}$ & $5 / 5$ & 1.5 & 1.8 & 77 \\
\hline $833^{c}$ & $1 / 1$ & d & 3.3 & $d$ \\
\hline $977^{e}$ & 100 & 1.7 & 2.3 & 2.6 \\
\hline \multicolumn{5}{|l|}{ Sulfate } \\
\hline $\begin{array}{l}\text { Background } \\
(969)\end{array}$ & $6 / 6$ & 1220 & 1300 & 1440 \\
\hline 833 & $1 / 1$ & d & 1930 & d \\
\hline 977 & $5 / 5$ & 1160 & 1320 & 1580 \\
\hline \multicolumn{5}{|l|}{ Sulfide } \\
\hline Background & $6 / 20$ & $<0.1$ & d & 55 \\
\hline 833 & $d$ & d & d & d \\
\hline 977 & $0 / 5$ & d & d & $d$ \\
\hline \multicolumn{5}{|l|}{ Thallium } \\
\hline Background & $1 / 22$ & $<0.01$ & d & 0.1 \\
\hline 833 & $0 / 1$ & d & d & d \\
\hline 977 & $0 / 5$ & $d$ & d & d \\
\hline
\end{tabular}


Table 3.3 Statistical summary of the Dilworth ground water quality at the Falls City, Texas, site (Continued)

\begin{tabular}{|c|c|c|c|c|}
\hline \multirow[b]{3}{*}{ Constituent } & \multirow{3}{*}{$\begin{array}{c}\text { Frequency of } \\
\text { detection }\end{array}$} & \multicolumn{3}{|c|}{ Observed concentration } \\
\hline & & Minimum & Median $^{a}$ & Maximum \\
\hline & & $(\mathrm{mg} / \mathrm{L})$ & $(\mathrm{mg} / \mathrm{L})$ & $(\mathrm{mg} / \mathrm{L})$ \\
\hline \multicolumn{5}{|l|}{ Tin } \\
\hline Background & $5 / 22$ & $<0.005$ & d & 0.019 \\
\hline 833 & $0 / 1$ & d & d & d \\
\hline 977 & $2 / 5$ & 0.01 & d & 0.02 \\
\hline \multicolumn{5}{|l|}{ Uranium } \\
\hline $\begin{array}{l}\text { Background } \\
(968)\end{array}$ & $5 / 5$ & 0.026 & 0.056 & 0.068 \\
\hline $833^{c}$ & $1 / 1$ & $d$ & 3.04 & d \\
\hline $977^{e}$ & $5 / 5$ & 0.016 & 0.023 & 0.054 \\
\hline \multicolumn{5}{|l|}{ Vanadium } \\
\hline Background & $10 / 22$ & $<0.01$ & d & 0.05 \\
\hline 833 & $0 / 1$ & d & d & d \\
\hline 977 & $1 / 5$ & $<0.01$ & $d$ & 0.03 \\
\hline \multicolumn{5}{|l|}{ Zinc } \\
\hline Background & $15 / 22$ & $<0.005$ & 0.012 & 0.544 \\
\hline 833 & $1 / 1$ & d & 0.213 & $d$ \\
\hline 977 & $5 / 5$ & 0.120 & 0.182 & 0.206 \\
\hline
\end{tabular}


Table 3.3 Statistical summary of the Dilworth ground water quality at the Falls City, Texas, site (Concluded)

\begin{tabular}{|c|c|c|c|c|}
\hline \multirow[b]{3}{*}{ Constituent } & \multirow{3}{*}{$\begin{array}{c}\text { Number of } \\
\text { samples }\end{array}$} & \multicolumn{3}{|c|}{ Observed concentration } \\
\hline & & Minimum & Median' & Maximum \\
\hline & & $(\mathrm{pCi} / \mathrm{L})$ & $(\mathrm{pCi} / \mathrm{L})$ & $(\mathrm{pCi} / \mathrm{L})$ \\
\hline \multicolumn{5}{|l|}{ Radionuclide } \\
\hline \multicolumn{5}{|l|}{ Lead-210 } \\
\hline Background $^{b}$ & 8 & 0.0 & 1.5 & 6.8 \\
\hline $833^{c}$ & 0 & d & d & d \\
\hline $977^{e}$ & 2 & 0.0 & 0.4 & 0.8 \\
\hline \multicolumn{5}{|l|}{ Polonium-210 } \\
\hline Background & 8 & 0.0 & 0.2 & 0.7 \\
\hline 833 & 0 & d & d & d \\
\hline 977 & 2 & 0.0 & 0.05 & 0.1 \\
\hline \multicolumn{5}{|l|}{ Radium-226 } \\
\hline Background (969) & 6 & 2.0 & 3.3 & 4.6 \\
\hline 833 & 1 & $d$ & 2.4 & $d$ \\
\hline 977 & 5 & 0.7 & 1.2 & 1.9 \\
\hline \multicolumn{5}{|l|}{ Thorium-230 } \\
\hline Background & 8 & 0.1 & 0.3 & 0.9 \\
\hline 833 & 0 & d & d & d \\
\hline 977 & 2 & 0.1 & 0.3 & 0.5 \\
\hline
\end{tabular}

The median, or 50 th percentile of the sample data, cannot be determined if 50 percent or less of the data are above detection.

bData are pooled from monitor wells $967,968,969$, and 979 unless one or more of these wells have significantly higher levels than the others. In such cases, background represents the higher levels.

CRepresents the western contaminated zone. Water quality data from one sampling round in December 1991 were used to determine constituents of concern for this contaminated zone.

Data not available.

'Represents the eastern contaminated zone. Water quality data from 1989 through 1991 were used to determine constituents of concern for the eastern contaminated zone.

Note: Filtered samples, 1989-1992. 


\subsubsection{Magnitude of site-related ground water contamination}

A statistical, geochemical, and hydrological analysis of the Falls City water quality data for 1989 through 1993 indicates tailings-related contamination in the Deweesville/Conquista aquifer, with less contamination in the Dilworth aquifer.

\section{Deweesville/Conquista}

Elevated levels of contaminants in the Deweesville/Conquista aquifer generally occur in four distinct contaminant zones (Figure 3.10). Ground water from some wells in these zones shows elevated levels of aluminum, arsenic, cadmium, manganese, molybdenum, selenium, sulfate, and uranium.

Although the four contaminated zones, including a possible southern arm of the eastern zone, show many chemical similarities, each contaminated zone has important chemical differences that give it a distinct geochemical signature. The locations of Deweesville/Conquista monitor wells are shown on Figure 3.10.

\section{Eastern contaminated zone}

The eastern contaminated zone originates from tailings pile 3. A major lobe of contamination extends approximately $3000 \mathrm{ft}(900 \mathrm{~m})$ north-northeast in ground water beneath Scared Dog Creek. The $\mathrm{pH}$ of contaminated ground water in several monitor wells along Scared Dog creek (e.g., 962, 963, 965, and 966) commonly ranges between 3 and 5 ; however, in some areas the contaminated zone is not acidic (e.g.. monitor wells 955 and 961) (DOE, 1992b). Monitor well 953, approximately $1200 \mathrm{ft}(3600 \mathrm{~m})$ east-southeast of pile 3 , also shows evidence of tailings-related contamination such as elevated uranium levels and low pH (DOE, 1992b). The lack of monitor wells in this zone south of tailings pile 3 precludes a more precise delineation of a possible southeastern lobe of the eastern contaminated zone.

\section{Northern contaminated zone}

The northern contaminated zone is associated primarily with former tailings piles 2 and 7. The pH of the ground water in this zone varies from about 3 in monitor well 625 to almost 7 in well 921 . Locally in this zone, sulfate levels are high (approximately 11,000 milligrams per liter [mg/L] in monitor well 625). The extremely high sulfate concentrations in this part of the Deweesville/Conquista aquifer probably were generated by a tailings pond that existed in the southern end of pile 2.

\section{Southern contaminated zone}

The primary source areas of the southern contaminated zone appear to be tailings piles 4 and 5 . The southern contaminated zone appears to extend as far as FM 791, approximately $2500 \mathrm{ft}(760 \mathrm{~m})$ southeast of the former processing 


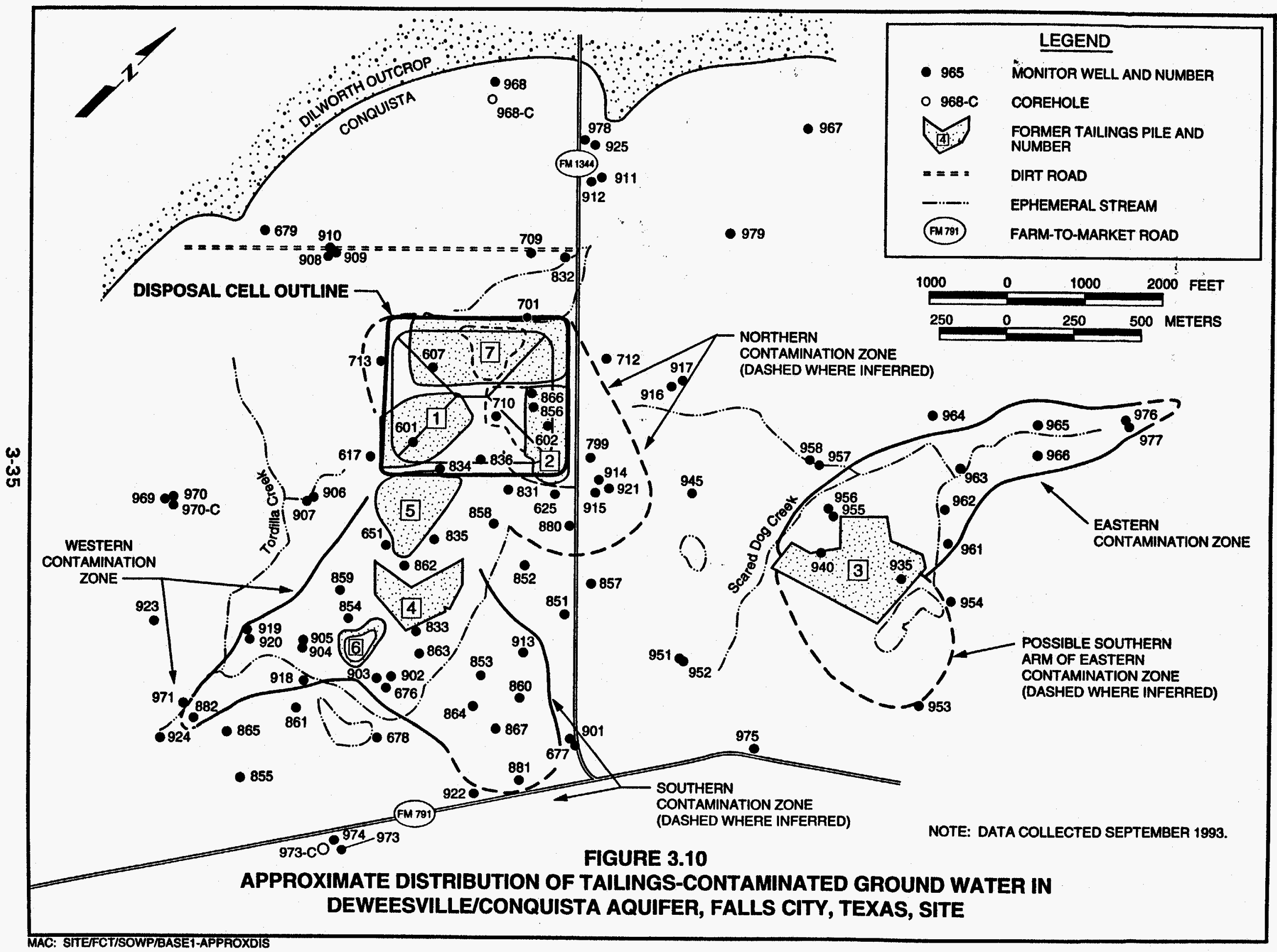


site. The contaminated zone is generally acidic, with pH.ranging from 3 to 4 and significantly higher chloride concentrations than other contaminated zones.

\section{Western contaminated zone}

Most of the western contaminated zone is acidic (e.g., monitor wells 854, 882, and 904). Ground water from monitor well 918 is only slightly acidic (pH of about 5) (DOE, 1992b). The southwest contaminated zone appears to originate from piles 4 and 5 . This contaminated zone extends more than $3000 \mathrm{ft}(900 \mathrm{~m})$ southwest of pile 4 and pond 6 in ground water beneath Tordilla Creek.

The area between former piles 4 and 5 contains a 1-to 3-ft $(0.3-$ to $1-\mathrm{m})$-thick zone of acid-, sulfate-, and possibly metals-rich ground water perched on top of a thin but laterally extensive silicified layer in the Deweesville/Conquista. The shallow perched saturated zone was probably generated by horizontal flow along this silicified layer when tailings leachate was injected into piles 4 and 5 during in situ mining operations (DOE, 1992b).

\section{Dilworth}

Contamination in the Dilworth aquifer was identified in monitor well 977 north of pile 3 , and in former monitor well 833 at the southern edge of pile 4 . Ground water sampled from monitor well 977 (sampled June 1991) is acidic (pH 4.23) and contains moderately elevated levels of aluminum $(1.02 \mathrm{mg} / \mathrm{L})$, iron $(1.4 \mathrm{mg} / \mathrm{L})$, sulfate $(1580 \mathrm{mg} / \mathrm{L})$, and uranium (0.054 mg/L) (DOE, 1992b).

Only two sampling rounds (February 1986 and December 1991) were conducted on monitor well 833 before it was abandoned during construction of the disposal cell. The decrease in alkalinity and $\mathrm{pH}$ and the significant increase in concentrations of ammonium, iron, manganese, sulfate, and uranium in the ground water from this well over time (DOE, 1992b) suggest the Dilworth is being contaminated in this area. New monitor wells at locations beneath the former tailings piles are needed to verify if the Dilworth is contaminated by processing site activities.

\subsubsection{Contaminant fate and transport}

The chemical species present in aqueous systems are a function of $\mathrm{pH}$, Eh, and the concentrations of different anions and cations. Speciation determines the mobility of the chemicals and might also influence their toxicity. The predominant species of the contaminants of concern for human health were predicted through the geochemical model MINTEOA2 (Allison et al., 1991). The contaminants of concern are identified in the site-specific baseline risk assessment (in preparation): cadmium, cobalt, fluoride, nickel, iron, sulfate, and uranium.

Constituents in the contaminated zone waters are subject to dilution and to different chemical reactions, including oxidation/reduction, precipitation and 
coprecipitation, possible reactions with biologic organisms, and adsorption onto aquifer mineral surfaces. The concentrations of the dominantly cationic metals and the major cations calcium, magnesium, potassium, and sodium are controlled by dilution and precipitation and sorption reactions. Cadmium, iron, cobalt, nickel, and fluoride concentrations will also be controlled by these processes. Chloride concentrations are affected only by dilution or evaporation. Attenuation mechanisms that should control the concentrations of the contaminants of concern for the Falls City site are discussed below.

\section{Cadmium}

Cadmium will be removed rapidly by the precipitation of otavite $\left(\mathrm{CdCO}_{3}\right)$ and hydrolysis reactions as the low pH of the tailings leachate is neutralized by alkaline ground water and the calcite in the aquifer matrix. Dilution with background water produces cadmium concentrations below detection limits in downgradient ground water. Elevated cadmuim levels are restricted to the areas underneath or immediately adjacent to the tailings pile.

\section{Iron, cobalt, and nickel}

Aqueous species of iron typically are not stable in ground water that is oxidizing and that has a pH near or above 6 . Dissolved iron in oxidizing water with a $\mathrm{pH}$ of 7 should oxidize rapidly and remove as iron oxyhydroxides. Although ground water from many downgradient monitor wells in the Deweesville/Conquista yields pH measurements below 4 and has iron levels significantly higher than reference well 951, ground water from only one Dilworth well (977) has an acidic $\mathrm{pH}$. The $\mathrm{pH}$ in ground water from Dilworth background well 969 is historically, between 6.5 and 7 (DOE, 1992b). Nonetheless, iron concentrations in these waters are well above the values present in the other Dilworth background wells at the site.

Elevated cobalt levels might have been introduced to the aquifer by acidic tailings leachate. Because of its chemical similarity to iron, however, cobalt typically coprecipitates during the precipitation of manganese and iron hydroxides. At the typical pH range $(6$ to 8$)$ observed for ground water in the Dilworth aquifer at the Falls City site, cobalt should be present at levels below or near the detection limit. Slightly elevated cobalt levels $(e .9 .$, up to $0.05 \mathrm{mg} / \mathrm{L}$ in monitor well 969) and iron levels could be expected in naturally reducing, alkaline, background Dilworth ground waters. More elevated cobalt concentrations can occur in low-pH contaminated ground water (up to 0.09 $\mathrm{mg} / \mathrm{L}$ in acidic Dilworth monitor well 977). When the $\mathrm{pH}$ of this oxidizing water increases to above 5.5, cobalt concentrations should be much lower.

\section{Sulfate}

Sulfate concentrations in the contaminated zones of the aquifer immediately adjacent to the processing site are controlled primarily by gypsum solubility. Farther downgradient, sulfate concentrations are controlled largely by physical 
processes such as dispersion and dilution. Reduction of sulfate to sulfide is also possible if the contaminated zone interacts with reducing sediment or ground water.

Gypsum precipitation predominately controls sulfate concentrations at the present time because the shallow ground water in and around the tailings piles was saturated with gypsum. As the tailings piles are consolidated and covered, the sulfate level in ground water around the former piles will decrease.

Eventually, as sulfate levels drop below gypsum saturation, the gypsum that has precipitated previously will begin to redissolve. The dissolution of gypsum will buffer the sulfate concentrations at fairly high levels until the gypsum supply is exhausted. At this point, natural flushing with background water will substantially lower the sulfate concentrations in the former tailings pile area.

Because the sulfate concentrations are high, adsorption reactions probably will not significantly affect sulfate concentrations in the shallow ground water. Given the high redox potential of the shallow ground water in the Deweesville/Conquista and Dilworth aquifers, sulfate removal by reduction to sulfide is not likely until the contamination migrates well off the site.

Uranium is mobile in acidic ground water (e.g., pH is 3 to 4) where it typically exists as positively charged uranyl, uranium hydroxyl, and (in high sulfate systems) uranium sulfate complexes. In oxidizing, alkaline ground water over a range of elevated $\mathrm{pH}$ values (e.g., between 6.5 and 8.5 ), uranium can form stable anionic carbonate complexes that facilitate uranium transport in ground water.

Uranium levels are elevated in both acidic and alkaline ground water at the Falls City site. In both these environments, uranium concentrations will be reduced mainly by adsorption onto aquifer materials and by dilution with uncontaminated ground water.

\subsubsection{Risk evaluation}

The uranium milling activities at the Falls City site led to ground water contamination in the Deweesville/Conquista and Dilworth aquifers and may have contaminated a third water-bearing member. The members are the Deweesville, the Conquista, and the Dilworth. For assessing risk to potential ground water users, the Deweesville and Conquista water-bearing members are evaluated as a single aquifer.

Residents near the site use ground water from the deeper Carrizo aquifer 12000 to $3000 \mathrm{ft}[600$ to $900 \mathrm{~m}]$ below the surface). Because of its depth below the land surface, the Carrizo aquifer is not affected by mining and milling activities at the Falls City site. 


\section{Dilworth aäuifer}

Ground water from the Dilworth aquifer was historically considered to be poor quality. No drinking-water wells are screened in the Dilworth aquifer within a $2-\mathrm{mi}(3-\mathrm{km})$ radius of the site (DOE, 1992b). Although the DOE does not have evidence of its use, ground water from the Dilworth aquifer might have been used for watering domestic stock and gardens in the vicinity of the site. Therefore, the potential future use of the Dilworth aquifer at the site was evaluated.

Levels of aluminum, ammonium, cadmium, cobalt, fluoride, iron, nickel, sulfate, uranium, and zinc in ground water from monitor wells and downgradient of the site were higher than the concentrations reported in the ground water from background wells. These potential contaminants of concern are presented in Table 3.4. High levels of arsenic and manganese occur naturally in some areas of the Dilworth aquifer. Both arsenic and manganese typically are associated with the uranium ore deposits found in the Falls City site area. Also, high levels of sulfate occur naturally in the Dilworth ground water and are associated with gypsum deposits.

Although zinc was observed above background, it was eliminated as a contaminant of potential concern because it is an essential nutrient, and the levels at which it is observed are within nutritional ranges, even when added to expected dietary intake. Ammonium and aluminum were eliminated as contaminants of potential concern based on low toxicity, and because the levels at which they are observed in the most contaminated downgradient monitor wells will not produce potential adverse health effects. Cadmium, cobalt, fluoride, iron, nickel, sulfate, and uranium remain as the contaminants of potential concern for the Dilworth.

Potential adverse health effects are a function of how much of the contaminants an individual takes into his or her body. The risk of exposure to humans was estimated by examining the four ways by which contaminants can enter the body: by drinking the water, eating garden produce irrigated with the water, eating meat from livestock which drank the water, or drinking milk from livestock which drank the water.

Considering these relevant human exposure pathways, small amounts of the contaminants could be passed from the livestock to humans or from garden produce to humans. The estimated amounts of contaminants that could be ingested would cause adverse health effects if the Dilworth aquifer background ground water is used to water domestic stock and irrigate gardens.

Iron and sulfate concentrations in the ground water make the human health risks associated with the potential future use of this ground water as a drinking water source unacceptable. The estimated iron exposure level could be associated with elevated levels of iron (above normal values) in internal organs such as the liver, pancreas, endocrine organs, and heart. Elevated levels of iron in the body 
Table 3.4 Contaminants of potential concern in the Dilworth aquifer

\begin{tabular}{lcccc}
\hline & \multicolumn{4}{c}{ Constituent levels and qualities } \\
\cline { 2 - 5 } \multicolumn{1}{c}{$\begin{array}{c}\text { Range in } \\
\text { Cockground } \\
\text { (mg/L) }\end{array}$} & $\begin{array}{c}\text { Frequency } \\
\text { of } \\
\text { detection }\end{array}$ & $\begin{array}{c}\text { Range in } \\
\text { contaminated } \\
\text { zone } \\
\text { (mg/L) }\end{array}$ & $\begin{array}{c}\text { Frequency } \\
\text { of detection }\end{array}$ \\
\hline Aluminum & $<0.05-0.05$ & $2 / 24$ & $0.45-1.02$ & $6 / 6$ \\
Ammonium & $<0.1-2.0$ & $14 / 24$ & $<0.1-5.7$ & $5 / 6$ \\
Cadmium & $<0.001-0.005$ & $7 / 26$ & $<0.001-0.022$ & $5 / 6$ \\
Cobalt & $0.01-0.05$ & $3 / 26$ & $0.06-0.09$ & $6 / 6$ \\
Fluoride & $0.4-0.5$ & $5 / 5$ & $<0.1-1.0$ & $2 / 5$ \\
Iron & $0.24-2.7$ & $8 / 8$ & $0.14-127$ & $7 / 7$ \\
Nickel & $<0.04$ & $2 / 26$ & $0.07-0.11$ & $6 / 6$ \\
Sulfate & $1220-1440$ & $8 / 8$ & $1160-1930$ & $7 / 7$ \\
Uranium & $0.026-0.094$ & $6 / 6$ & $0.016-3.04$ & $7 / 7$ \\
Zinc & $<0.005-0.54$ & $19 / 26$ & $0.12-0.21$ & $6 / 6$ \\
\hline
\end{tabular}

${ }^{2}$ The number of samples at or above detection limits divided by the total number of samples.

Note: Statistical comparison was made to the 0.05 level of significance. 
would lead to increased skin pigmentation and possibly cirrhosis of the liver. Although no drinking water wells are within a $2-\mathrm{mi}(3-\mathrm{km})$ radius of the site, if the Dilworth ground water were used as drinking water for infants, sulfate levels could result in severe persistent diarrhea potentially leading to dehydration, because infants are sensitive to sulfate toxicity. Laxative effects could be produced in adults who drink the water. Moreover, natural levels of sulfate present in the Dilworth ground water near the site, and typically found in this area of Texas, are known to produce diarrhea in some individuals.

Human health would not be at risk from exposure to cadmium, cobalt, fluoride, and nickel through these pathways. Exposure to uranium is hazardous because of its chemical toxicity and potential radiological damage. Chemical toxicity from exposure to uranium is not anticipated if humans drink the Dilworth ground water. The additional cancer risk from radioactive uranium and longer-lived uranium decay series, however, is at an unacceptable level of 1 in 1000 over a lifetime. Any excess lifetime cancer risks associated with radionuclides due to human ingestion of garden produce irrigated with the Dilworth contaminated ground water and consumption of meat or milk from cattle that have drunk this water are within an acceptable range. The National Contingency Plan range is between 1 in 10,000 and 1 in 1,000,000.

The levels of manganese and arsenic observed in the natural Dilworth ground water that is unaffected by the former mill tailings could lead to an increased risk of developing nervous system disorders resembling Parkinson's disease and/or skin cancer. Naturally occurring manganese and arsenic, therefore, limit the potential use of ground water in some areas as a source for drinking water.

An evaluation of the potential effects on livestock, if the Dilworth ground water were used to water cattle, showed livestock would suffer no adverse health effects from drinking Dilworth ground water. The Dilworth ground water is also suitable for crop irrigation.

\section{Deweesville/Conquista aquifer}

Although no livestock, domestic, or drinking water wells are screened in the Deweesville/Conquista aquifer within a $2-\mathrm{mi}(3-\mathrm{km})$ radius of the site, the use of Deweesville/Conquista ground water downgradient and farther than $2 \mathrm{mi}(3 \mathrm{~km})$ from the site has not been evaluated. The shallow ground water at the Falls City site appears to have originated largely from past in situ mining and milling operations and its use as a water supply is unlikely. Although the DOE has not determined if the ground water in the Deweesville/Conquista farther downgradient from the site is a usable water resource, historically, it has not been used as a drinking-water source.

The background water quality in the Deweesville/Conquista aquifer was partially assessed before surface remedial action began. Sulfate, manganese, and uranium concentrations in the Deweesville/Conquista ground water are high enough to cause serious adverse health effects. The health effects associated 
with exposure to sulfate, manganese, and uranium (found in preceding sections describing the adverse health affects caused by exposure to ground water from the Dilworth aquiferl make the ground water unsuitable for drinking, irrigating crops, or watering livestock. Other hazardous and radiologic contaminants are present at elevated levels in ground water from the Deweesville/Conquista aquifer; however, additional data must be collected to establish a list of contaminants and their range of concentrations.

\subsection{EVALUATION OF INTERIM ACTION OPPORTUNITIES}

The DOE has determined there is no immediate danger to public health and the environment from contaminated ground water because no wells are completed in the aquifer of concern and the rural water supply provides good quality water to residents in the site vicinity. Therefore, interim action is not planned at the Falls City site. 


\subsection{GROUND WATER COMPLIANCE STRATEGY SELECTION}

The ground water compliance strategies for the Falls City site and an explanation of the application of site-specific data to the ground water compliance selection framework are presented below (Figure 4.1).

\subsection{COMPLIANCE STRATEGY SELECTION PROCESS}

A health- and environmental risk-based framework for selecting site-specific compliance strategies is being applied to each UMTRA Project processing site. This compliance selection framework was developed in the UMTRA Ground Water PEIS. The framework enables the DOE to apply the same criteria to determine the ground water compliance strategy at each site and to determine the appropriate compliance strategy.

A step-by-step approach is followed until one or a combination of three compliance strategies below is selected for a specific site.

- No remediation. Compliance with the proposed standards would be met without altering the ground water or cleaning it up in any way. This strategy could be applied at sites with contamination at or below maximum concentration limits or background levels or at sites that have contamination above maximum concentration limits or background levels but qualify for supplemental standards or ACLs.

- Natural flushing. Allows natural ground water movement and geochemical processes to decrease contaminant concentrations to levels within regulatory limits within a given time period. This strategy could be applied at sites where ground water compliance would be achieved with natural flushing within 100 years, where effective monitoring and institutional controls could be maintained, and where the ground water is not and is not projected to be a drinking water source.

- Active ground water remediation. Requires application of engineered ground water remediation methods such as gradient manipulation, ground water extraction and treatment, and in situ ground water treatment to achieve compliance with the proposed standards.

\subsection{FALLS CITY, TEXAS COMPLIANCE STRATEGY SELECTION}

The ground water compliance selection framework was applied to the two aquifers known to be affected by activities at the processing site. The site conditions at the Falls City site were used to determine that the no-remediation application of supplemental standards strategy would be appropriate for both the Dilworth and Deweesville/Conquista aquifers based on widespread ambient contamination and acceptable risks to human health and the environment.

Figure 4.1 shows how this decision was made. 
CHARACTERIZE PLUME AND

HYDROLOGICAL CONDITIONS USING

EXISTING DATA AND NEW DATA AS

REOUIRED.

\section{IS GAOUND WATER CONTAMINATION PRESENT IN EXCESS OF MAXIMUM CONCENTRATION LUMTSS OR BACKGROUND?}

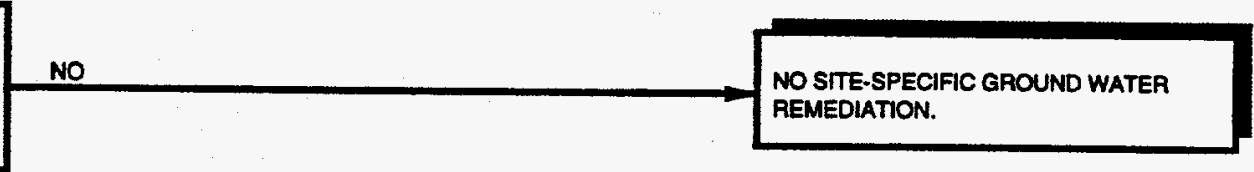

YES
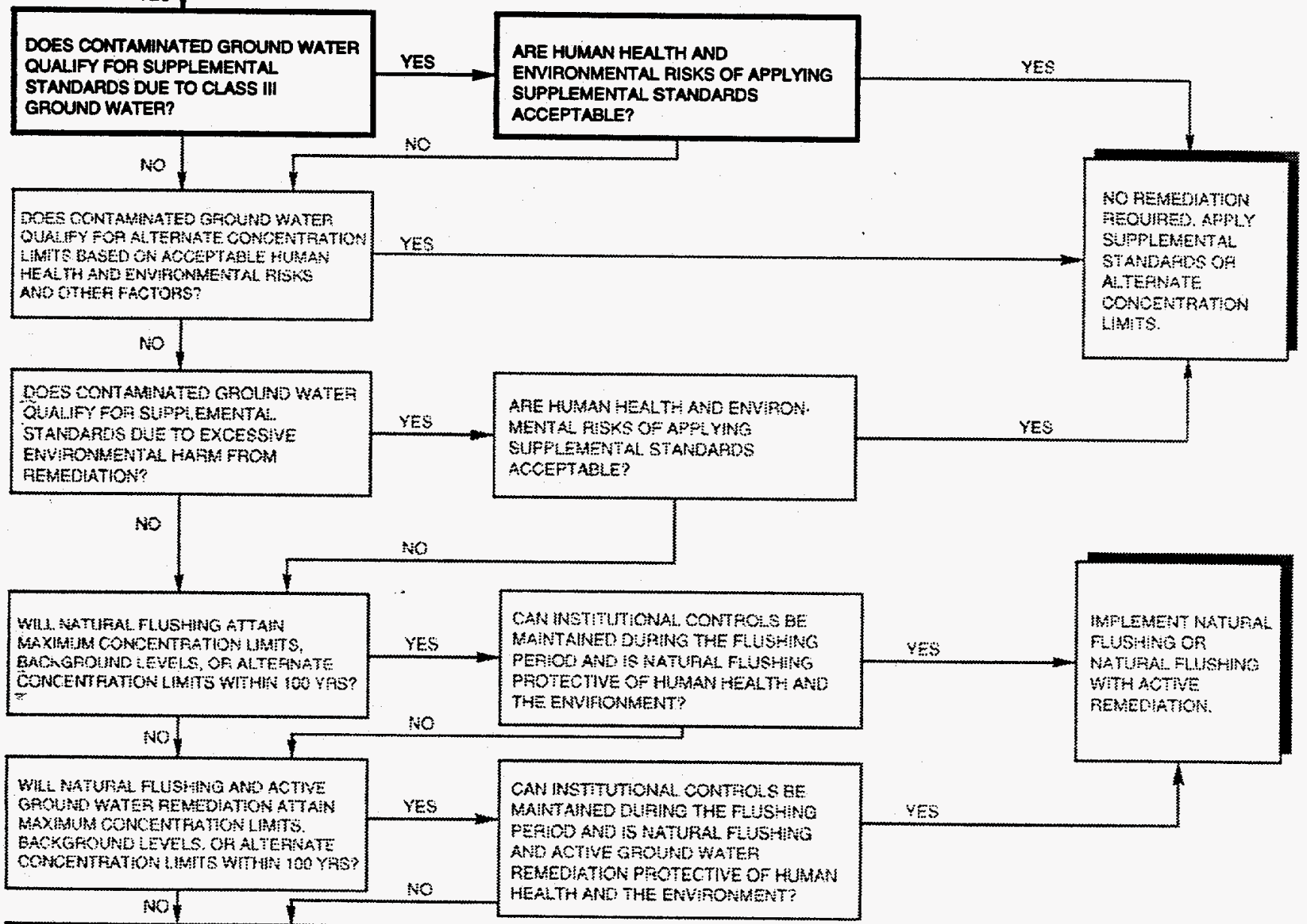

WHL ACTVE CROUNO WATER P.EMEDDATLN METHOOS ATTAIN EACKOFOUND MAXMULA

CONCENTRATONLLATIS OR

ALTEFNATE CONCEMTPATON LHATS?

$$
\text { Nol }
$$

APFLY SUPPLEMENT SE STANDAFDS BASED ON TECHAVEA IMPAACTECAGILTT AND APFLY INSTITUTIONAL CONTROLS WHEFE $A E E D E D$.
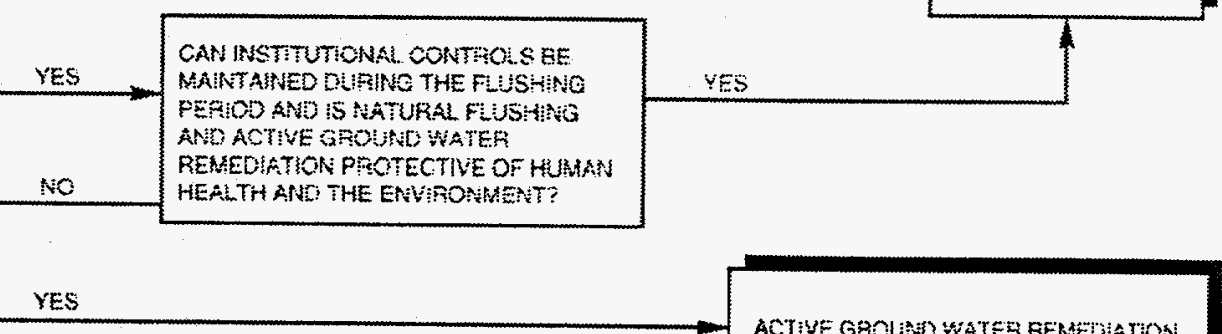
FiUSintio on NATUFAA FLISHINO WTH AOTEE REMECHATON

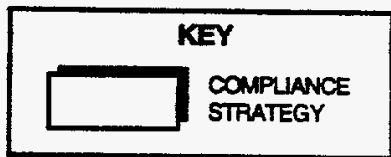

FIGURE 4.1

FRAMEWORK APPLICATION OF CONTAMINANTS OF POTENTIAL CONCERN IN THE DILWORTH AND DEWEESVILLE/CONQUISTA AQUIFERS 
Figure 4.1 shows how the framework was used to prepare the Dilworth aquifer strategy of no remediation and the application of supplemental standards. Table 4.1 shows how each of the contaminants of concern move through the framework.

To protect ground water and to achieve compliance with proposed EPA ground water standards under the UMTRA Surface Project (Subpart A of 40 CFR Part 192 (1994)), the DOE proposed a narrative supplemental standard for Parcel A of the Falls City site and the disposal site. The supplemental standard for surface remedial action classified ground water from the Dilworth Member as Class III, based on widespread ambient contamination that could not be cleaned up with methods reasonably employed by public water systems. To demonstrate existing widespread contamination in the Dilworth aquifer, the DOE established background ground water quality in the site vicinity (DOE, 1992b). Supplemental standards did not apply to Parcel B of the Falls City site.

$\therefore \quad$ However, there is no evidence conditions are different in the aquifer in the vicinity of Parcel $B$. The DOE, NRC, and the state concurred with the supplemental standard application and agreed that Dilworth ground water was Class III in 1992. Thus, the first step toward achieving compliance with the ground water standards under Subpart B of 40 CFR Part 192 was to determine if widespread, ambient contamination persists in the Dilworth aquifer in the site vicinity.

The second step was to determine if compliance with the proposed standards could still be achieved by applying supplemental standards based on Class III (limited use) ground water. Regulations define Class III ground water as ground water that is not a current or potential source of drinking water because 1 ) the concentration of total dissolved solids exceeds $10,000 \mathrm{mg} / \mathrm{L} ; 2)$ widespread. ambient contamination not caused by activities involving RRM from a designated processing site that cannot be cleaned up with treatment methods reasonably employed by public water-supply systems; or 3) the quantity of water available from a well is less than 150 gallons (570 liters) per day.

Hydrogeologic conditions and ground water contamination conditions at the Falls City site have been characterized and are presented in Section 3.0. The background water in the Dilworth aquifer still meets the criteria for Class III ground water based on widespread, ambient contamination not caused by activities involving RRM from a designated processing site. The background water cannot be cleaned up with treatment methods reasonably employed by public water-supply systems. Making water from the Dilworth aquifer potable would require multiple treatment technologies not typically used in Texas or in the region. Removing radionuclides from the ground water will produce treatment plant wastes containing both hazardous and radioactive constituents. Also, treated Dilworth ground water would cost local residents considerably more than what they now pay for drinking water (DOE, 1992b). 


\begin{tabular}{|c|c|c|c|c|c|}
\hline \multirow[b]{2}{*}{ Contaminant } & \multicolumn{5}{|c|}{ Criteria } \\
\hline & $\begin{array}{c}\text { Are new data } \\
\text { required? }\end{array}$ & $\begin{array}{c}\text { Does contamination } \\
\text { exceed background } \\
\text { or MCLs? }\end{array}$ & $\begin{array}{l}\text { Is contaminant } \\
\text { found in Class III } \\
\text { ground water? }\end{array}$ & $\begin{array}{l}\text { Are human health } \\
\text { and environmental } \\
\text { risks of applying } \\
\text { supplemental } \\
\text { standards } \\
\text { acceptable? }\end{array}$ & $\begin{array}{c}\text { Apply } \\
\text { supplemental } \\
\text { standards? }\end{array}$ \\
\hline Aluminum & No & Yes & Yes & Yes & Yes \\
\hline Ammonium & No & Yes & Yes & Yes & Yes \\
\hline Cadmium & No & Yes & Yes & Yes & Yes \\
\hline Cobalt & No & Yes & Yes & Yes & Yes \\
\hline Fluoride & Yes & Yes & Yes & Yes & Yes \\
\hline Iron & Yes & Yes & Yes & Unknown ${ }^{a}$ & Unknown \\
\hline Nickel & No & Yes & Yes & Yes & Yes \\
\hline Sulfate & Yes & Yes & Yes & Unknown ${ }^{a}$ & Unknown \\
\hline Uranium & Yes & Yes & Yes & Unknown ${ }^{a}$ & Unknown \\
\hline Zinc & No & Yes & Yes & Yes & Yes \\
\hline
\end{tabular}


The DOE has determined from the data that supplemental standards are protective of human health and the environment, and that site-specific remediation is not required. Section 3.3.5 describes the limited uses of ground water from the Dilworth and the risk associated with exposure to iron and sulfate in the ground water. Because the DOE is proposing supplemental standard as a compliance strategy, however, it will analyze exposure pathways and collect additional data to demonstrate that existing or potentially beneficial uses of ground water are protected; the pathway analysis and data collection activities are discussed further in Section 5.0.

\section{Deweesville/Conquista aquifer compliance strategy}

Figure 4.1 shows how the framework was used to prepare the strategy of no remediation supplemental standards were applied to the Deweesville/Conquista aquifer. Hence, the proposed compliance strategy is identical to the strategy proposed for the Dilworth aquifer.

Before beginning surface remedial action, the DOE established that widespread ambient contamination existed in the Deweesville/Conquista aquifer and that the contamination could not be cleaned up with methods reasonably employed by public water systems. Therefore, the ground water was a Class III (limited use) source. Background monitor wells were installed and monitored to demonstrate widespread ambient contamination of the Deweesville/Conquista aquifer in the vicinity of Parcel A and the disposal site. The NRC and the state agreed that the DOE had adequately demonstrated background ground water quality and that ground water from the Deweesville/Conquista aquifer was Class III. Hence, the first step toward achieving compliance with the ground water standards under Subpart B of 40 CFR Part 192 was to determine whether naturally occurring widespread ambient contamination still exists in this aquifer in the site vicinity.

The second step was to determine whether compliance with the proposed standards could still be achieved by applying supplemental standards based on Class III (limited use) ground water. The current hydrogeologic conditions and ground water contamination conditions at the Falls City site have been characterized (Section 3.0). The quality of the background ground water in the Deweesville/Conquista aquifer remains poor and still meets the criteria for Class III ground water based on widespread, ambient contamination not caused by activities involving RRM from a designated processing site. The background water cannot be cleaned up with treatment methods reasonably employed by public water-supply systems. To make water from the Deweesville/Conquista aquifer potable would require multiple treatment technologies not typically used in Texas or in the region. Removing radionuclides from the ground water will produce treatment plant wastes containing both hazardous and radioactive constituents. Also, treated Deweesville/Conquista ground water will cost local residents considerably more than what they now pay for drinking water (DOE, 1992b). 
The DOE has determined from the data that supplemental standards are protective of human health and the environment and that site-specific remediation is not required. There are no current uses of the Deweesville/Conquista ground water (Section 3.3.5). The risks associated with exposure to uranium, manganese, and sulfate in ground water are described in Section 3.3.5. The risks associated with other contaminants in the Deweesville/Conquista ground water will be assessed after additional data are collected. Because the DOE is proposing supplemental standard as a compliance strategy, it will analyze exposure pathways and collect additional data to demonstrate that existing or potentially beneficial uses of ground water are protected. The pathway analysis and data collection activities are discussed further in Section 5.0.

\subsection{DEVIATIONS, CONTINGENCIES, AND DECISION RULES}

The ground water compliance selection framework uses a health- and risk-based approach to achieve compliance with EPA regulations for UMTRA processing sites. Several contaminated zones of the Deweesville/Conquista aquifer already extend into private property. Consequently, some property owners may object to the DOE health- and risk-based analysis, and the application of supplemental standards to contaminated ground water. In such a case, the DOE may be compelled to implement alternative approaches to protect potential future beneficial uses of the ground water. After additional data are collected, the DOE will decide if alternative approaches should be assessed for protecting potential beneficial uses of ground water in the site vicinity. 


\subsection{DATA COLLECTION AND ASSESSMENT}

\section{$5.1 \quad$ STATEMENT OF DATA NEEDS}

The DOE has evaluated existing site information and has found data gaps (uncertainties) that must be addressed to confirm the appropriateness of the proposed ground water compliance strategy and the feasibility of active remediation methods, if required. The compliance strategy might require active remediation methods if the proposed primary compliance strategy is unacceptable to the public, regulatory agencies, or both.

Specific activities that DOE proposes to correct data deficiencies are described below. These activities are designed to enhance understanding of site conditions and to ensure the appropriate ground water compliance strategy or remedial action is implemented.

\subsubsection{Qualitative analysis of background ground water quality}

Background ground water quality in the Deweesville/Conquista aquifer has been sufficiently characterized to demonstrate that it qualifies for a supplemental standard application (DOE, 1992b). However, a literature search and a review of ground water quality data from monitor wells and other wells near the site will be conducted to demonstrate qualitatively that the supplemental standards are protective of potential beneficial uses of ground water in the site vicinity.

\subsubsection{Land and water use survey}

The DOE must demonstrate that the ground water compliance strategy will protect human health and the environment. To evaluate the health risks and environmental impacts associated with ground water contamination. investigators must identify potential exposure pathways within and downgradient from the contaminated zones and assess the likelihood of direct or indirect human contact with contaminated ground water through the exposure pathways.

\subsubsection{Hydrogeologic investigations}

\section{Installing monitor wells and ground water sampling}

The DOE must further define the extent and degree of contamination in the Deweesville/Conquista and Dilworth aquifers, refine its understanding of ground water flow direction, assess the potential affects of the contamination on other aquifers, and assess potential beneficial uses of those aquifers. 


\section{Water level monitoring}

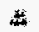

Water levels will be monitored during aquifer tests in the four contaminated zones in the Deweesville/Conquista aquifer to observe short- and long-term fluctuations in ground water levels. Water levels also will be monitored during aquifer tests conducted in the Dilworth aquifer to observe the degree of interconnection with the Deweesville/Conquista aquifer.

\section{Aquifer testing}

Aquifer tests are proposed to more accurately quantify the aquifer properties to determine ground water velocities and to obtain the data needed to design an effective remediation system, if required.

\section{Core analysis}

Core analyses will be conducted on archived core and newly collected core samples to estimate effective porosity and grain size distribution. Microbes in the subsurface soils should be identified, and their population density determined.

\subsubsection{Geochemical analysis of subsurface samples}

Deweesville/Conquista sediments will be analyzed to determine the sediment's ability to attenuate contamination migrating from the four areas of contamination.

\subsection{DATA COLLECTION OBJECTIVES}

This investigation has established the following data collection objectives:

- Further define background ground water quality data of the Deweesville/Conquista aquifer. Background ground water quality will be defined qualitatively through a literature search and by reviewing ground water quality data from existing wells.

- Identify potential exposure pathways downgradient of the site. This includes collecting data to help identify potential routes of contaminant migration from the site to an existing or potential point of contact.

- Determine the nature and occurrence of ground water recharge for the Deweesville/Conquista aquifer.

- Define the extent of downgradient contamination in the Deweesville/ Conquista aquifer in each of the contaminated zones described in Section 3.3.2. 
- Define the degree of contamination in the Dilworth aquifer immediately downgradient of the disposal cell (the location of former tailings pile 1, 2, 3, 4,5 , and 7).

- Define the area of variability in aquifer hydraulic conductivity to estimate advective velocities.

- Determine the degree of interconnection between the Deweesville/Conquista and Dilworth aquifers.

- Define the capacity of natural sediments to attenuate ground water contaminants and their ability to neutralize acidic ground water.

\subsection{DATA QUALITY OBJECTIVES}

The purpose of a data quality objectives (DOO) is to ensure that data of known and appropriate quality are obtained during an investigation and to ensure the data are adequate to support DOE, state, and public decisions for remedial action. The DOOs for each task proposed in Section 5.1 are presented below.

\subsubsection{Qualitative analysis of background ground water quality}

Literature and records will be searched for data. The quality of the data sources will be based on its merits and its applicability to Falls City site conditions. For example, reports issued by state or federal agencies are assumed to be accurate and reliable sources of information.

\subsubsection{Land and water use survey}

For the water use survey, investigators will attempt to obtain well construction and water use information from at least 90 percent of the former and existing domestic wells in the Deweesville/Conquista and Dilworth aquifers. The horizontal positions of domestic wells and stock ponds will be determined with a global positioning system (GPS) instrument. The horizontal accuracy of most GPS terminals is 1 radial meter or less.

\subsubsection{Hydrogeologic investigations}

\section{Installing monitor wells, and ground water sampling and analysis}

A hydrogeologist will be present during all phases of borehole drilling and well installation. Boreholes will be logged and monitor wells will be installed following procedures described in standard operating procedures (SOP) 14.1.3, 14.4.1, 16.1.5.4.3.2, and 16.1.2 (JEG, n.d.). The TAC has specified or established procedures for installing and developing monitor wells, sampling water and soil, preserving and transporting samples, filing procedures, chain-ofcustody, analyzing sample, quality assurance (QA), and managing and validating analytical data. Fieldwork is conducted in accordance with these SOPs, which 
are reviewed annually and updated (as appropriate) to reflect changes in industry standards, best management practices, and DOE or EPA guidelines.

Each well site will be properly permitted, and as much as possible, restored to preinstallation conditions. Wastes generated by the drilling operations (drilling fluid and well water) will be disposed of according to the procedures outlined in the Technical Approach for the Management of UMTRA Ground Water Investigation-Derived Wastes (DOE, 1994b).

The well casing will consist of 4-inch- $(100-\mathrm{mm})$ diameter, schedule 40 PVC pipe with flush-threaded joints. Solvent glues will not be used and couplings will not obstruct the well annulus, with no potential for screws to enter the inside of the casing and obstruct placement of the pump. Schedule 40 PVC pipe is large enough to allow the placement of a standard electric submersible pump designed for 4-inch $(100 \mathrm{~mm})$ diameter wells.

New monitor wells will be sampled twice in 1994 and twice in 1995 to determine different water quality parameters. At least four sampling rounds are required to create a statistically defensible data base. Samples will be collected, preserved, and shipped according to the UMTRA Project SOPs (JEG, n.d.). Because the new results will be compared to and grouped with previous results, the laboratory QA level must match previous QA levels. Thus, a laboratory Level $D$ will be used for the chemical analyses of the samples (DOE, 1990).

\section{Water level monitoring}

The purpose of water level monitoring is to observe short- and long-term fluctuations in ground water levels and determine the rate of ground water mound dissipation immediately downgradient of the disposal cell. Sufficient sensitivity, accuracy, and temporal recording resolution are needed to ensure the collected data can be used for their intended purpose. Standard pressure transducers (e.g., In Situ $\left.{ }^{*}\right)$ have a resolution of $0.004 \mathrm{ft}(0.001 \mathrm{~m})$ with an accuracy of $0.035 \mathrm{ft}(0.01 \mathrm{~m})$. Using standard equipment and procedures should provide sufficient accuracy to compute declining or rising ground water elevations. Water level data will be measured daily with data loggers for a minimum of 2 years.

\section{Aquifer testing}

Slug tests and short- and long-term aquifer testing and analyses will determine the spatial distribution of hydraulic conductivity, quantify how the aquifer would respond to conditions similar to active remediation, and (combined with core and slug test data) provide a data base sufficient for stochastic modeling analysis. Standard data loggers and pressure transducers, used in accordance with the manufacturer's instructions, will produce reliable data for the analyses. Tests will be designed and analyzed according to standards, such as American Society for Testing Materials (ASTM) standard D4050-1991 (ASTM, 1994a). The $\mathrm{pH}$, oxidation/reduction potential, specific conductivity, and temperature of 
the water will be checked every 15 minutes using standard field instrumentation and operating procedures. Aquifer tests are the most accurate method for determining the field values of hydraulic conductivity.

A potential problem with analyzing aquifer pumping tests is the possibility that pumping rate variations can create multiple solutions (Horne, 1994). To alleviate the problem of nonunique solutions, each test will be analyzed during both the drawdown and recovery phases. The recovery phase has a constant rate of zero and will provide a more accurate result. Slug tests are useful for estimating near-well bore parameters.

\section{Core/analysis}

Core analysis for porosity, bulk density, grain size, and microbe type and population will provide more detailed, small-scale information on aquifer characteristics. Core tests will relate the parameters determined on a small portion of the aquifer (cubic centimeters) to the macroscopic behavior of the aquifer (cubic kilometers). Laboratories qualified by the DOE will conduct the soil, geotechnical, and biological analyses.

\subsubsection{Geochemical analysis of subsurface samples}

Fresh core and test pit samples will be collected and properly preserved to determine neutralization capability, distribution coefficients, and total adsorption capacity. Fresh rather than archived samples will be used because it is not known what changes might have occurred to the cores during the last several years of storage. Following standard testing procedures ASTM Method 4319 (ASTM, 1994b) and standard laboratory QA procedures will generate data suitable for this activity.

\subsection{DATA COLLECTION ACTIVITIES}

To achieve the data collection objectives of this investigation, the DOE will collect ground water quality data for the Deweesville/Conquista aquifer to determine if the ground water still meets Class III ground water criteria. In addition, land and water use in the site vicinity will be defined to demonstrate that the proposed ground water compliance strategy will be protective of human health and environment.

\subsubsection{Qualitative analysis of background ground water quality}

A literature search and a review of ground water quality data for former and current wells will be used to qualitatively assess background ground water quality in the site area. The literature search will locate relevant reports or documents from state and federal agencies and professional journals, and information collected by mining companies that worked in the area. The water use survey discussed below will obtain relevant data from local property owners. 


\subsubsection{Land and water use survey}

The survey will extend up to $4 \mathrm{mi}(6 \mathrm{~km})$ radially from the site (Figure 5.1). This survey will expand the area of the previous survey, which was conducted within a $2-\mathrm{mi}(3-\mathrm{km})$ radius of the site.

During the land and water use survey, the following activities will be conducted:

- A literature search and review of ground water quality data from existing wells to further define background ground water quality.

- A well record search by reviewing appropriate files from the state of Texas. The well records will help to determine well construction information, depth to water, well productivity information, and water quality.

- Aerial photography of the region to quickly locate and identify stockponds that could be used to water livestock.

- A door-to-door survey to interview local landowners regarding past and present land and water use. Domestic wells and stock ponds will be located and sampled, if possible. Depth-to-water will be measured in domestic wells.

- Determine the horizontal and vertical position of domestic wells and surface water bodies, including those that have been identified but not located. Because of the size of the survey area lapproximately 25 square miles [65 square kilometers]), the DOE proposes using a GPS to locate the position of domestic wells and stock ponds with respect to the site.

\subsubsection{Hydrogeologic investigations}

Nine additional monitor wells will be installed on the site. Table 5.1 summarizes the proposed depth, screened interval, and the purpose of each new well. Figure $\mathbf{5 . 2}$ shows the proposed locations of these new wells. The exact locations are dependent on obtaining access agreements from landowners. After the monitor wells are installed, they will be surveyed by a registered land surveyor, or with a GPS.

- One well (883) will be installed immediately downgradient of the site southeast of FM 791 (Figure 5.2) to determine the extent of contamination in the southern contaminated zone.

- Four monitor wells will determine the extent of ground water contamination in the Deweesville/Conquista aquifer caused by former tailings pile 3 . Three of these monitor wells $(884,885$, and 886$)$ will be south of former tailings pile 3 and north of FM 791 (Figure 5.2) to determine the extent of contamination in the southern arm of the eastern contaminated zone. These monitor wells may help determine the impact of the Conquista tailings pile 


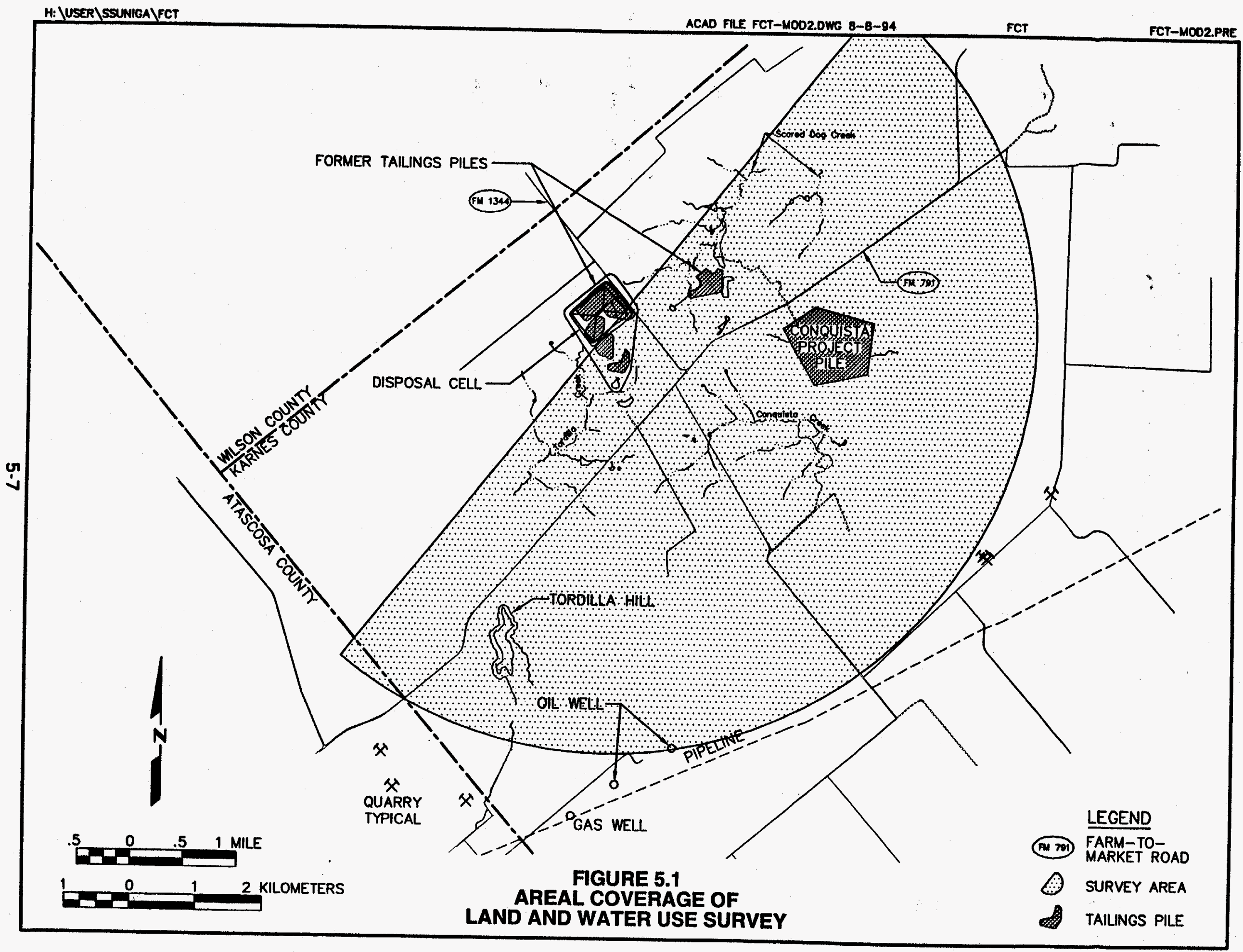


Table 5.1 Construction summary of proposed monitor wells

\begin{tabular}{|c|c|c|c|c|}
\hline Well iD & $\begin{array}{c}\text { Well } \\
\text { depth } \\
\text { (ft) }\end{array}$ & $\begin{array}{l}\text { Estimated } \\
\text { depth to } \\
\text { water } \\
\text { (ft) }\end{array}$ & $\begin{array}{c}\text { Screened } \\
\text { interval } \\
(\mathrm{ft})\end{array}$ & Purpose \\
\hline 883 & 90 & 70 & $70-90$ & $\begin{array}{l}\text { Define extent of contamination in southern } \\
\text { contaminated zone in Deweesville/Conquista } \\
\text { aquifer }\end{array}$ \\
\hline 884 & 80 & 40 & $50-80$ & $\begin{array}{l}\text { Define extent of contamination in contaminated } \\
\text { zone south of former tailings pile } 3 \text { in Deweesville/ } \\
\text { Conquista aquifer }\end{array}$ \\
\hline 885 & 55 & 45 & $45-55$ & $\begin{array}{l}\text { Define extent of contamination in contaminated } \\
\text { zone south of former tailings pile } 3 \text { in Deweesville/ } \\
\text { Conquista aquifer }\end{array}$ \\
\hline 886 & 60 & 50 & $50-60$ & $\begin{array}{l}\text { Define extent of contamination in contaminated } \\
\text { zone south of former tailings pile } 3 \text { in Deweesville/ } \\
\text { Conquista aquifer }\end{array}$ \\
\hline 887 & 50 & 40 & $40-50$ & $\begin{array}{l}\text { Define extent of contamination in eastern } \\
\text { contaminated zone along Scared Dog Creek in } \\
\text { Deweesville/Conquista aquifer }\end{array}$ \\
\hline 888 & 50 & 35 & $40-50$ & $\begin{array}{l}\text { Define extent of northern contaminated zone in } \\
\text { Deweesville/Conquista aquifer }\end{array}$ \\
\hline 889 & 50 & 35 & $40-50$ & $\begin{array}{l}\text { Define extent of northern contaminated zone in } \\
\text { Deweesville/Conquista aquifer }\end{array}$ \\
\hline 890 & 160 & 100 & $140-160$ & $\begin{array}{l}\text { Define extent of contamination in Dilworth aquifer } \\
\text { immediately downgradient of disposal cell }\end{array}$ \\
\hline 891 & 160 & 100 & $140-160$ & $\begin{array}{l}\text { Define extent of contamination in the Dilworth } \\
\text { aquifer beneath former tailings piles }\end{array}$ \\
\hline
\end{tabular}




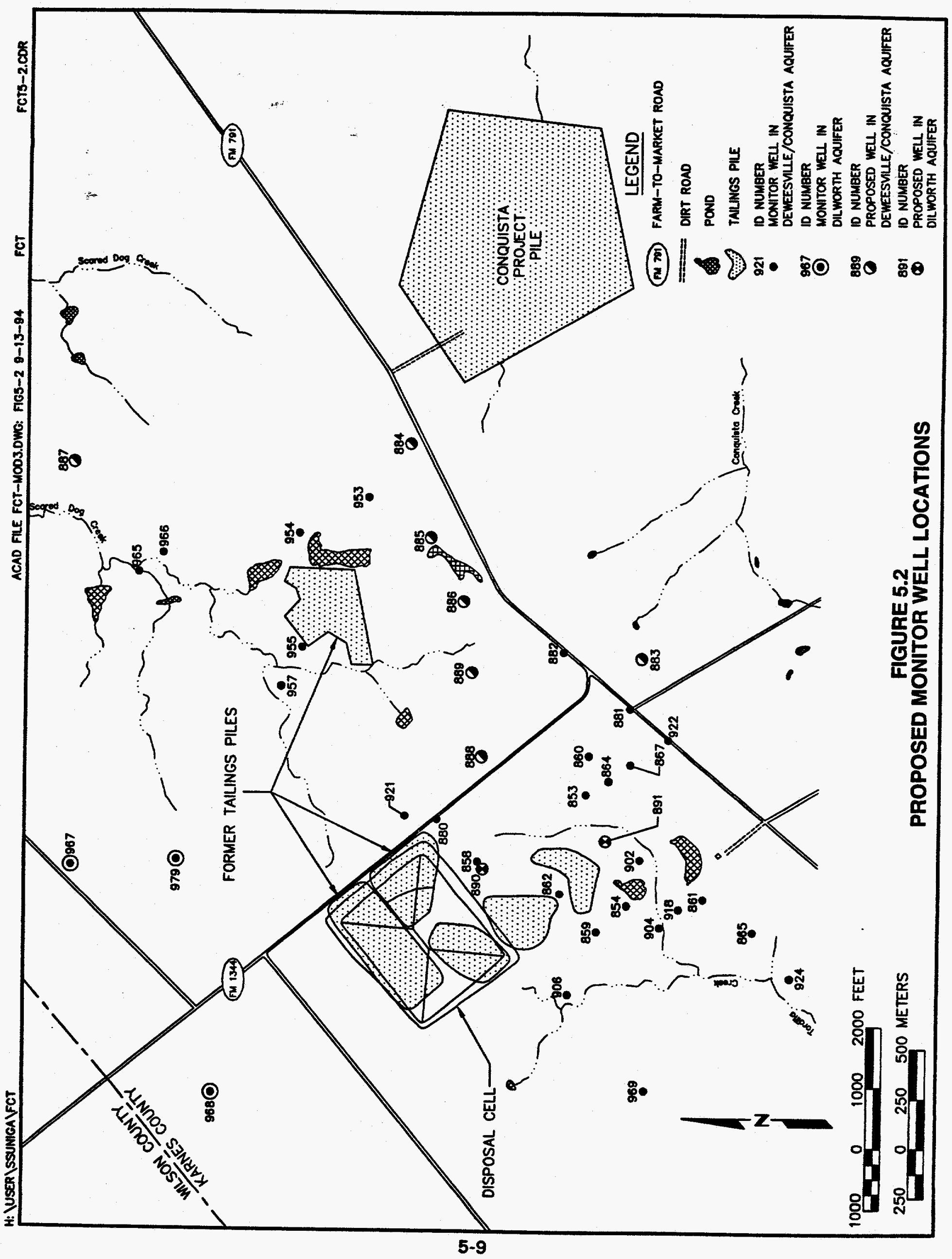


on ground water flow and quality in the Deweesville/Conquista aquifer. The fourth monitor well (887), along Scared Dog Creek just northeast of monitor well 977, will determine the extent of contamination in the eastern contaminated zone.

- Two monitor wells $(888$ and 889 ) will determine the extent of ground water contamination in the Deweesville/Conquista aquifer in the northern contaminated zone.

- Two monitor wells (890 and 891 ) downgradient of the disposal cell will quantify the amount of ground water contamination in the Dilworth aquifer and the associated health risks. These monitor wells will be paired with existing monitor wells screened in the Deweesville/Conquista aquifer (monitor wells 858 and 863). Pairing the shallow and deep wells will help determine the degree of interconnection between the Deweesville/Conquista and Dilworth aquifers. Construction methods for the wells installed in the Dilworth aquifer will minimize the potential of cross contamination from the overlying Deweesville/Conquista aquifer.

Each well, including the new monitor wells, will be sampled for the contaminants of concern identified in the baseline risk assessment. The new monitor wells will be sampled for a complete set of parameters during the first two sampling rounds in fiscal year 1995 to identify new potential contaminants of concern. Field analyses for $\mathrm{pH}$, oxidation-reduction potential, dissolved oxygen, specific conductance, and temperature will be conducted.

\section{Water level monitoring}

Water table hydrographs constructed during infiltration events will be used to analyze the nature and occurrence of ground water recharge in the Deweesville/ Conquista aquifer. Daily rainfall data will be obtained from Conoco's Conquista Project site, which is on FM 791 approximately $1.5 \mathrm{mi}(2.4 \mathrm{~km})$ east of the Falls City site (Figure 3.7). The monitoring period will be a minimum of 2 years.

Monitor wells near the disposal cell will be monitored for a minimum of 2 years to determine the rate of ground water mound dissipation immediately downgradient of disposal cell.

\section{Aquifer testing}

Slugs tests will be conducted in a selected group of monitor wells screened in one of the four contaminated zones of the Deweesville/Conquista aquifer (Section 3.3.2). At least three and perhaps four slug tests will be conducted in each contaminated zone to provide adequate information on the spatial distribution of hydraulic conductivity. If possible, at least one monitor well in each contaminated zone will be tested in each aquifer. During each aquifer test, water levels will be measured in nearby monitor wells to determine the extent of 
influence of the pumped well and the aquifer hydraulic parameters between the pumped well and each monitor well.

During each aquifer test, $\mathrm{pH}$, oxidation-reduction, and specific conductivity will be measured periodically. Also, time-sequenced ground water sampling will be conducted for selected constituents during each aquifer test.

Aquifer pumping tests will be conducted in the two newly installed wells screened in the Dilworth aquifer (adjacent to monitor wells screened in the Deweesville/Conquista aquifer). These tests will help determine hydraulic conductivity within the Dilworth and the degree of interconnection between the Dilworth and the overlying Deweesville/Conquista aquifers.

\section{Core analysis}

A geotechnical engineering laboratory will analyze both previously collected cores and newly collected core samples for porosity, specific yield, and grainsize distribution. Grain-size analyses from the core samples will determine the most efficient filter pack and screen slot size for new wells.

\subsubsection{Geochemical analysis of Deweesville/Conquista sediments}

Sediments from the Deweesville Sandstone and Conquista Clay will be collected for geochemical testing to determine their ability to neutralize contaminated zone acidity and to attenuate specific contaminants. Shallow sediment samples will be collected by using a backhoe to dig test pits. Deeper samples will be collected with a drill rig. Sediment samples will be collected in the reducing zones and sent to a laboratory to determine the following aquifer matrix properties:

- Acid neutralization potential.

- Distribution coefficient, $K_{d}$ (partitioning solutes between liquid and solid phases in the aquifer matrix).

- Total adsorption capacity.

Distribution coefficients and total adsorption capacities of the aquifer matrix will be determined for iron, manganese, molybdenum, and sulfate. Sediment samples also will be amended with other materials (e.g., limestone) and tested for the same matrix properties.

\subsection{RESULTS AND EVALUATION OF DATA COLLECTION ACTIVITIES}

When each data collection activity is complete, a report will be compiled and delivered to the DOE. The report will describe field activities, instrumentation used, and survey locations. It will contain copies of field measurement data, copies of field logs and notebooks, and methods of interpretation; and it will 
summarize the results relative to the data collection objective. A proposed ground water flow model will integrate detailed, site-specific information. The model also will allow quantitative evaluation of the flow rates required to meet the selected remedial strategy and the possible effects of the uncertainties in the conceptual model. The modeling, data results, and reports will be incorporated in the final SOWP. 


\subsection{LIST OF CONTRIBUTORS}

The following individuals contributed to the preparation of this report.

\begin{tabular}{ll}
\hline Name & Contribution \\
\hline E. Storms & Principal author \\
J. Crain & Document coordinator \\
E. Storms, J. Crain, J. Blount, & Technical authors \\
B. Malczewska-Toth, & \\
M. Gawthrop-Cooper & \\
E. Storms & Hydrogeology \\
J. Blount & Geochemistry \\
J. Crain & Engineering \\
B. Malczewska-Toth & Risk assessment \\
M. Gawthrop-Cooper & Regulatory compliance \\
L. Sanchez & Word processing \\
S. Suniga, B. Harvey & Graphic design \\
J. Torline & Technical editing, document production coordination \\
\hline
\end{tabular}




\subsection{REFERENCES}

Allison, J. D., D. S. Brown, and K. J. Novo-Gradac, 1991. MINTEQA2/PRODEFA2, A Geochemical Assessment Model for Environmental Systems: Version 3.0 User's Manual, EPA/600/3-91/021, Environmental Research Laboratory, Office of Research and Development, U.S. Environmental Protection Agency, Athens, Georgia.

ASTM (American Society for Testing Materials), 1994a. ASTM Standards on Ground Water and Vadose Zone Investigations, 2nd edition, Philadelphia, Pennsylvania.

ASTM (American Society for Testing Materials), 1994b. Annual book of ASTM Standards1994, Volume 04.08, "Soil and Rock, Building Stones, Geotextiles," Philadelphia, Pennsylvania.

BEG (Bureau of Economic Geology), 1992. Hydrogeology and Hydrochemistry of Falls City Uranium Mine Tailings Remedial Action Project, Karnes County, Texas, The University of Texas at Austin, Austin, Texas.

Bunker, C. M., and J. A. MacKallor, 1973. "Geology of the Oxidized Uranium Ore Deposits of the Tordilla Hill-Deweesville Area, Karnes County, Texas; A Study of a District Before Mining," U.S. Geological Survey Professional Paper 765, Washington, D.C.

DOE (U.S. Department of Energy), 1994a. Programmatic Environmental Impact Statement for the Uranium Mill Tailings Remedial Action Ground Water Project, draft, DOE/EIS-0198, Rev. 3, April 1994, prepared by the U.S. Department of Energy, UMTRA Project Office, Albuquerque Operations Office, Albuquerque, New Mexico.

DOE (U.S. Department of Energy), 1994b. Technical Approach for the Management of UMTRA Ground Water investigation-Derived Wastes, DOE/AL/62350-109, prepared by the U.S. Department of Energy, UMTRA Project Office, Albuquerque Operations Office, Albuquerque, New Mexico.

DOE (U.S. Department of Energy), 1993a. Technical Approach to Groundwater Restoration, final, DOE/AL/62350-2OF. November 1993, prepared by the U.S. Department of Energy, UMTRA Project Office, Albuquerque Operations Office, Albuquerque, New Mexico.

DOE (U.S. Department of Energy), 1993b. Recommendations for the Preparation of Environmental Assessments and Environmental Impact Statements, Office of NEPA Oversight, U.S. Department of Energy, Washington, D.C.

DOE (U.S. Department of Energy), 1992a. UMTRA Groundwater Program Plan, prepared by the U.S. Department of Energy, UMTRA Project Office, Albuquerque Operations Office, Albuquerque, New Mexico. 
DOE (U.S. Department of Energy), 1992b. Remedial Action Plan and Site Design for Stabilization of the Inactive Uranium Mill Tailings Site at Falls City, Texas, final, UMTRA-DOE/AL-050520.0000, DOE UMTRA Project Office, Albuquerque Operations Office, Albuquerque, New Mexico.

DOE (U.S. Department of Energy), 1990. Requirements for Quality Control of Analytical Data, DOE/HWP-65/R1, Rev. 1, U.S. Department of Energy, Oak Ridge Operations Office, Oak Ridge, Tennessee.

Eargle et al. (D. H. Eargle, G. W. Hinds, and A. Weeks), 1971. "Uranium Geology and Mines, South Texas," Guidebook 12, The University of Texas at Austin, Bureau of Economic Geology, Austin, Texas.

EPA (U.S. Environmental Protection Agency), 1989. Risk Assessment Guidance for Superfund, Volume I, Human Health Evaluation Manual, Part A, Interim Final, EPA/540/1-89/002, Office of Solid Waste, Waste Management Division, Washington, D.C.

FBDU (Ford, Bacon, and Davis Utah Inc.), 1981. Engineering Assessment of Inactive Uranium Mill Tailings: Falls City Site, Falls City, Texas, DOE/UMTRA-0111, FBDU 360-16, UC-70, Contract No. DE-AC04-76GJ01658, prepared by FBDU, Salt Lake City, Utah, for the U.S. Department of Energy, UMTRA Project Office, Albuquerque Operations Office, Albuquerque, New Mexico.

GECR (Geochemistry and Environmental Chemistry Research, Inc.), 1983. Data for the Geochemical Investigation of UMTRAP Designated Site at Falls City, Texas, prepared by GECR for the U.S. Department of Energy, UMTRA Project Office, Albuquerque Operations Office, Albuquerque, New Mexico.

Horne, R. N., 1994. "Advances in Computer-Aided Well-Test Interpretation," in Journal of Petroleum Technology, Vol. 46, No. 7, pp. 599-607.

JEG (Jacobs Engineering Group Inc.), n.d. Albuquerque Operations Manual, standard operating procedures, prepared by Jacobs Engineering Group, Albuquerque, New Mexico, for the U.S. Department of Energy, UMTRA Project Office, Albuquerque Operations Office, Albuquerque, New Mexico.

Kallus, Malone F., 1975. "Environmental Aspects of Uranium Mining and Milling in South Texas," EPA-906/9-75-004, U.S. Environmental Protection Agency Region VI, Houston, Texas.

Merritt, R. C., 1971. The Extractive Metallurgy of Uranium, Colorado School of Mines Research Institute, Golden, Colorado.

NOAA (National Oceanic and Atmospheric Administration), 1979. Climatic Atlas of the United States, National Climate Center, Ashville, North Carolina. 
TK\&A (Turk, Kehle, \& Associates), 1976. "Reconnaissance Hydrogeology of Uranium Mill Tailings, Falls City, Texas," report prepared for Ford, Bacon \& Davis Utah Inc.. Salt Lake City, Utah.

USGS (U.S. Geological Survey), 1988. A Modular Three-Dimensional Finite-Difference Ground-Water Flow Model, Technique of Water Resource Investigations 06-A1.

\section{CODE OF FEDERAL REGULATIONS}

10 CFR Part 1021, National Environmental Policy Act; Implementing Procedures and Guidelines Revocation; Final Rule and Notice, National Archives and Records Administration (1994).

40 CFR Part 192, Health and Environmental Protection Standards for Uranium and Thorium Mill Tailings, U.S. Environmental Protection Agency (1994).

40 CFR Part 1500, Purpose, Policy, and Mandate, Council on Environmental Quality (1994).

\section{UNITED STATES CODES}

42 USC $\$ 4321$ et seq.. National Environmental Policy Act, January 1, 1970.

42 USC $\$ 7901$ et seq., Uranium Mill Tailings Radiation Control Act, November 8, 1978.

42 USC $\$ 7922$ et seq. , Uranium Mill Tailings Remedial Action Amendments Act, November 5, 1988.

\section{FEDERAL REGISTER}

52 FR 36000, Standards for Remedial Action at Inactive Uranium Processing Sites;

Proposed Rule, September 24, 1987. 
APPENDIX

CALCULATION FCT-06-91-12-01-00 


\section{CALCULATION COVER SHEEI}

CALC NP.ECT-x-91-12-01-00 DIS CIPLINE Enquacecing/hydedogy NO. OF OHEETS 10 PAOJECT:

$$
\text { UMTRA }
$$

\section{SITE:}

$$
\text { Files CITY }
$$

FEATUAE:

SURFACE WATER MASS BALANCE

SOURCES OF DATA:

see pagel of text

SOURCES OF FORMULAE O REFERENCES:

$$
\text { see text }
$$

\begin{tabular}{|c|c|c|c|c|c|c|c|}
\hline$\infty 0$ & & 0. Camin & $621 / 9$ & 30 & $6 / 26 / 91$ & PBont & 6k6lal \\
\hline & & & & & & & \\
\hline & & & & & & & \\
\hline & & & & & & & \\
\hline $\begin{array}{l}\text { as } r . \\
\text { wo. }\end{array}$ & aEvision & $\begin{array}{c}\text { EALEULATION } \\
\text { Or }\end{array}$ & DATE & $\begin{array}{c}\text { CMEEXED } \\
\text { OY }\end{array}$ & DATE & $\begin{array}{c}\text { Apphoreo } \\
\text { er }\end{array}$ & DATE \\
\hline
\end{tabular}

prelmimary calc. $\square$ final calc. $\square$ supensedes calc. no. 
JACOBS ENGINEERING

oute-6/21/91

SUBJECT

SHEET NO. $1 / 10$

or ODC CHKD.

JOB NO

1. Problem statement

Estimate the volume of ur ter that may have eccumulated on Pare " $A$ " of the Falls city site during the timers) the mill was in operation

2. Data

1. precipitation data -National Climatic Data Center, Asheville, North Carolina

a. weather station - located inside city limits Falls City, Texas

b. periel-if-record: August 1946 through November 190 2. information on discharge e rates to pouch and depth of ponds from former mill supervisor (Susguelianna Western) kirin E. Wiatrek, phone: $512-780-3911$

3. Assumptions

a maximum pond area is equal to area of tailing file minus 6 ares to

b. rainfall-volume (column 3 of tables) is inches of precipitation times the maximum pored area. 
JACOBS ENGINEERING

DATE_ $6 / 21 / 91$

or $90 \mathrm{C}$ CHKD.
SUBJECT
SHEET NO. $2 / 10$

JOB NO.

c for computing evaporative surface area (column 6 - O tables)

Where diked drainage areas are used the mater surface ada may be expressed as a variable function dependent on pond volume $D$ ked retention areas may be modeled as conical volumes. The surface area when the pad is less than foll is approximated by:

$$
A=K A_{F}\left(V_{P} / V_{F}\right)^{2 / 3}
$$

where: $A_{F}=$ maximum water surface area

$V_{F}=$ maximum volume

$V_{p}=$ monthly volume (processing

$k=1.0$ for accumulating conditions

d. infiltration is not consiclered in the mass balance. A diagram of He mass balance is presented below

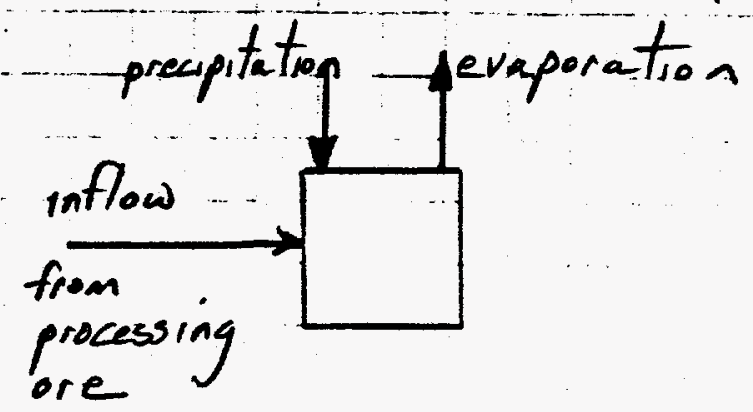


$5: 362 t-1$ rowwes soving ssow 8-5isofif (sogt) oruy/eq ssow or: 26od $\left(2 / 9^{\circ}+\right)^{2} 77$ liguiw frowwing is

\begin{tabular}{|c|c|c|}
\hline 9 & 宀b & $2:$ \\
\hline 9 & 97 & $\Xi$ \\
\hline 7 & $\angle$ & ty \\
\hline 9 & 0 & $E$ \\
\hline 9 & $8 t$ & $\tau$ \\
\hline 3934 & 30.120 & - \\
\hline$\because \mathrm{HL}-\mathrm{HO}$ & 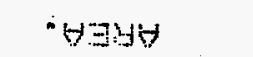 & \\
\hline Grod & onot & \\
\hline friti I xth & HWIXYA & \\
\hline
\end{tabular}

sobotud st

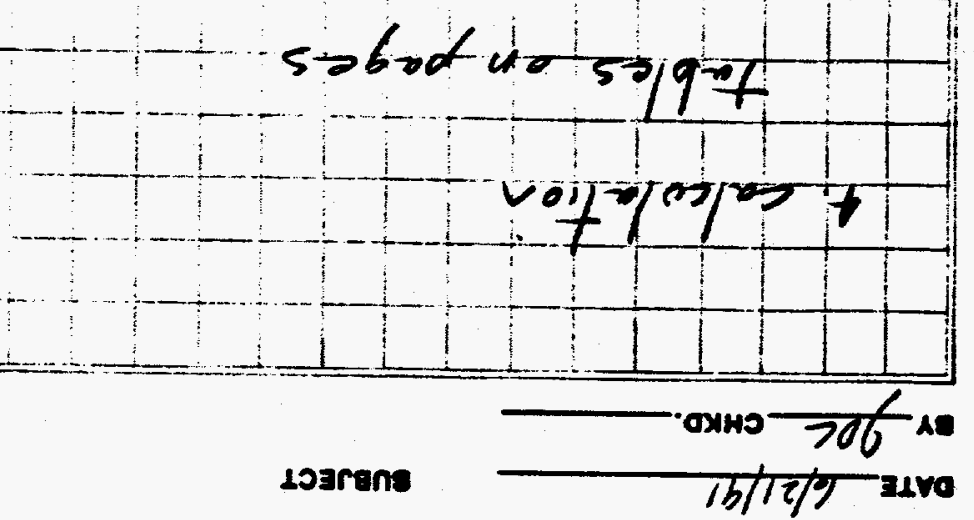


FALLS CITY, TEXAS PILE ND. 1

APRIL 1961 TKROUEH DECEREER 1963

AVERASE AMHLGL LAKE EVAPORATION = 54 inEhEE

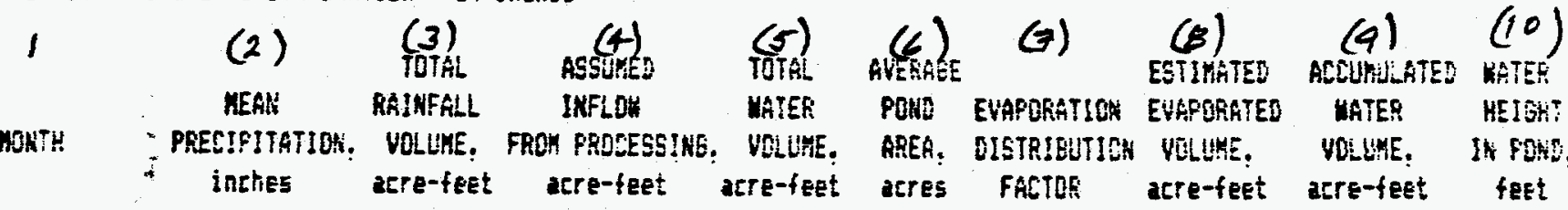

\begin{tabular}{|c|c|c|c|c|c|c|c|c|c|c|}
\hline \multirow[t]{9}{*}{$196 !$} & APR & 2.45 & 3.68 & 3 & 6.68 & 5.85 & 0.082 & 2.16 & 4.52 & 3.42 \\
\hline & MẹY & 3.73 & 5.59 & 3 & 8.60 & 6.93 & 0.102 & 3.18 & 5.42 & 3.72 \\
\hline & JUN & 2.89 & 4.33 & 3 & 7.33 & 6.23 & $0 .: 27$ & 3.56 & 3.77 & 3.53 \\
\hline & IUL & 1.53 & 2.75 & 3 & 5.75 & 5.30 & 0.143 & $3.4 !$ & 2.34 & 3.25 \\
\hline & AUE & 2.51 & 3.77 & 3 & 6.76 & 5.91 & 0.133 & 3.53 & 3.23 & 3.44 \\
\hline & SEF & 3.86 & 5.79 & 3 & B. 79 & 7.03 & 0.096 & 3.04 & 5.75 & 3.75 \\
\hline & $\Delta c^{T}$ & 2.95 & 4.43 & 3 & 7.43 & $6.2 E$ & 0.071 & 2.01 & 5.42 & 3.54 \\
\hline & Mot & 2.2 & 3.63 & 3 & 6.63 & 5.47 & 0.049 & 2.21 & 4.82 & 3.31 \\
\hline & DES & $2.4 E$ & 2.22 & 3 & 5.22 & 4.97 & 0.039 & 0.87 & 4.35 & 3.15 \\
\hline \multirow[t]{12}{*}{1962} & JAN & 1.58 & 2.37 & 3 & 5.37 & 5.06 & 0.039 & 0.87 & 4.48 & 3.28 \\
\hline & FEE & $\therefore .70$ & 2.55 & 3 & 5.55 & 5.18 & 0.046 & 1.07 & 4.48 & 3.2 \\
\hline & $\mathrm{MAR}$ & 1.08 & 1.62 & 3 & 4.62 & 4.58 & 0.073 & 1.50 & 3.12 & 3.03 \\
\hline & AFE & 2.45 & 3.68 & 3 & $6.6 \varepsilon$ & 5.85 & 0.082 & 2.16 & 4.52 & 3.42 \\
\hline & $M A Y=$ & 3.73 & 5.59 & 3 & 8.60 & 6.93 & 0.502 & $3.1 E$ & 5.42 & 3.72 \\
\hline & נ: & 2.89 & 4.33 & $i$ & 7.33 & 6.23 & 0.227 & $3.5 k$ & 3.77 & 3.5 \\
\hline & $d i d i$ & 1.83 & 2.75 & 3 & 5.75 & 5.30 & 0.143 & $3.4 !$ & 2.24 & 3.25 \\
\hline & AUE & $2.5 !$ & 3.77 & 3 & 6.76 & $5.9 !$ & 0.133 & 3.53 & 3.23 & 3.45 \\
\hline & SEP & 3.86 & 5.79 & 3 & 6.79 & 7.6 & 0.076 & 3.4 & 5.75 & 3.75 \\
\hline & OLT & 2.95 & 4.43 & 3 & 7.43 & 6.28 & 0.071 & $2.0 !$ & 5.42 & 5.54 \\
\hline & $\sin$ & 2.02 & 3.3 & 3 & 6.03 & 5.47 & 0.647 & 2.21 & 4.5 & 3.31 \\
\hline & $I E C$ & $\therefore .4 E$ & 2.22 & 3 & 5.22 & 4.97 & 0.037 & C.E? & 4.35 & 2.25 \\
\hline \multirow[t]{12}{*}{$: 953$} & 今日! & 1.55 & 2.37 & 3 & 5.37 & 5.06 & 0.039 & 0.97 & 4.43 & $\therefore .10$ \\
\hline & FEE & 1.70 & 2.55 & 3 & 5.55 & 5.18 & 0.046 & 1.07 & 4.48 & 32 \\
\hline & MAR & 1.08 & 1.22 & 3 & 4.32 & 4.58 & 0.073 & 2.50 & 2.12 & 300 \\
\hline & 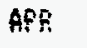 & 2.45 & 3.68 & $z$ & 6.55 & 5.25 & 0.082 & 2.16 & 4.52 & 3.42 \\
\hline & NA: & 3.73 & 5.55 & 3 & 8.60 & 6.93 & $6 .: 02$ & $3.1 E$ & 5.42 & $\therefore .72$ \\
\hline & $31 \mathrm{k}$ & 2.85 & $4.3 ?$ & 3 & 7.3 & 5.23 & 0.127 & 3.52 & 3.77 & 3.5 \\
\hline & 80 & 1.83 & 2.75 & 3 & 5.75 & $5.3 \mathrm{t}$ & 6.145 & $3.4 !$ & 2.34 & 3.25 \\
\hline & Aus & 2.51 & 3.77 & 3 & 6.76 & 5.91 & 0.153 & 3.53 & 3.23 & 5.44 \\
\hline & SEF & 3.86 & 5.79 & 3 & 8.75 & 7.03 & 0.096 & 3.04 & 5.75 & 3.75 \\
\hline & OCT & 2.95 & 4.43 & 3 & 7.43 & 6.28 & 0.071 & 2.01 & 5.42 & 3.54 \\
\hline & MEV & 2.62 & 3.03 & 3 & 6.03 & 5.47 & 0.049 & 1.21 & $4 . \varepsilon 2$ & 3.31 \\
\hline & DEC & 1.49 & 2.22 & 3 & 5.22 & 4.97 & 0.039 & 0.87 & 4.35 & 3.15 \\
\hline 1964 & JAS & 2.53 & 2.37 & 3 & 5.37 & 5.06 & 0.039 & 6.89 & 4.48 & 3.12 \\
\hline
\end{tabular}


FALLE RITT. TEXAS PILE NO. 2

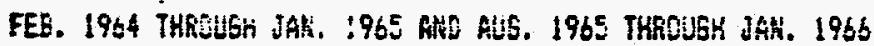

AUERAGE ANWUAL LAKE EUARORATICN = 54 inchES
a)
G)
(3)
(4)
(5) (C)
(G)
(9) (0)
RAINFALL INFLOH
MATES
EETINATES ACCHHULATED WATER

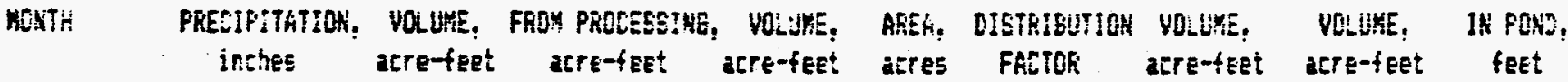

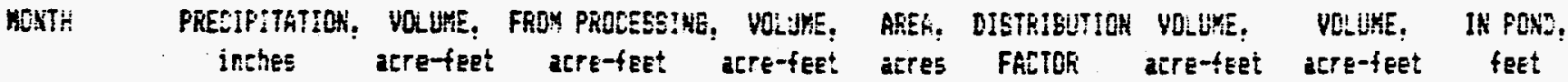

\begin{tabular}{|c|c|c|c|c|c|c|c|c|c|c|}
\hline \multirow[t]{11}{*}{1964} & FEE & 1.30 & 2.83 & 3 & 5.83 & 5.54 & 0.046 & 1.15 & 4.69 & 3.16 \\
\hline & $M_{k 5}$ & 1.08 & 5.80 & 3 & 4.80 & 4.97 & 0.073 & 1.60 & 3.20 & 2.96 \\
\hline & APR & 2.45 & 4.08 & 3 & 7.08 & 6.31 & 0.082 & 2.37 & 4.76 & 3.37 \\
\hline & KAY & 3.72 & 6.22 & 3 & 9.22 & 7.52 & 0.102 & 3.45 & 5.77 & 3.68 \\
\hline & $d u$ & 2.89 & 4.82 & 3 & 7.82 & 6.73 & 0.127 & 3.85 & 3.97 & 3.48 \\
\hline & IUt & 4.83 & 3.05 & 3 & 6.05 & 5.68 & 0.143 & 3.65 & 2.40 & 3.20 \\
\hline & A.UE & 2.51 & 4.18 & 3 & 7.18 & 6.37 & 0.133 & $3.8:$ & 3.37 & 3.39 \\
\hline & SEF & 3.86 & 6.43 & 3 & 9.43 & 7.63 & 0.076 & 3.30 & 6.14 & 5.71 \\
\hline & DCT & 2.95 & 4.92 & 3 & 7.92 & 6.79 & 0.071 & 2.17 & 5.75 & 3.50 \\
\hline & $\Delta J^{\prime}$ & 2.02 & 3.37 & 3 & 6.37 & $5.8 ?$ & 0. 0.49 & 1.30 & 5.07 & 3.25 \\
\hline & DE & 1.48 & 2.47 & 3 & 5.47 & 5.31 & 0.035 & 0.93 & 4.54 & 3.09 \\
\hline \multirow[t]{14}{*}{1965} & JAK & 1.58 & 2.63 & 3 & 5.65 & 5.41 & 0.038 & 0.95 & $4.6 \varepsilon$ & $3 .: 2$ \\
\hline & FEE & 1.70 & 2.53 & 0 & 2.83 & 3.42 & $0.04 t$ & $0.7:$ & 2.12 & 2.42 \\
\hline & MAR & 1.08 & 1.E: & 0 & 1.50 & 2.53 & 0.073 & $0 . E^{3}$ & 6. 77 & 2.53 \\
\hline & APR & 2.45 & $4.0 E$ & 0 & 4.08 & 4.37 & 0.082 & 1.6! & 2.47 & 2.80 \\
\hline & MEY & 3.73 & 6.22 & 0 & 6.22 & 5.78 & 0.102 & 2.65 & 3.56 & 3.23 \\
\hline & s.t. & 2.89 & 4.82 & 0 & 4.32 & 4.83 & 0.127 & 2.79 & 2.03 & 2.96 \\
\hline & IUL & $\{.83$ & 3.05 & 0 & 3.05 & 3.60 & 0.143 & $2.3 \mathrm{i}$ & 0.74 & 2.5 \\
\hline & AUE & 2.51 & $4.1 E$ & 3 & 7.18 & 6.37 & 0.133 & $3.5 !$ & 3.37 & 3.5 \\
\hline & SEP & 3.86 & 6.43 & 3 & $9.4 j$ & 2.63 & 0.096 & 3.30 & 6.14 & $3.7:$ \\
\hline & OCT & 2.95 & 4.92 & 3 & 7.92 & 6.79 & $0.07 !$ & $2 .: 7$ & 5.7E & 3.50 \\
\hline & 104 & 2.62 & $3.3 ?$ & 3 & 6.37 & $5.8 ?$ & 0.049 & 1.30 & 5.07 & 3.25 \\
\hline & DEE & $1.4 E$ & 2.47 & 3 & 5.47 & $5.3 !$ & 0.035 & 0.82 & 4.54 & 3.19 \\
\hline & 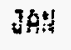 & 1.5E & 2.65 & 3 & 5.63 & 5.4: & 0.039 & 0.95 & 4.68 & $2 .: 2$ \\
\hline & FEE & $\therefore .70$ & 2.83 & 3 & 5.83 & 5.54 & $0.04 t$ & 1.25 & $4.5 \%$ & $3.1 t$ \\
\hline
\end{tabular}


ร40

$7-3915052$

$52 \quad 9+6 !$

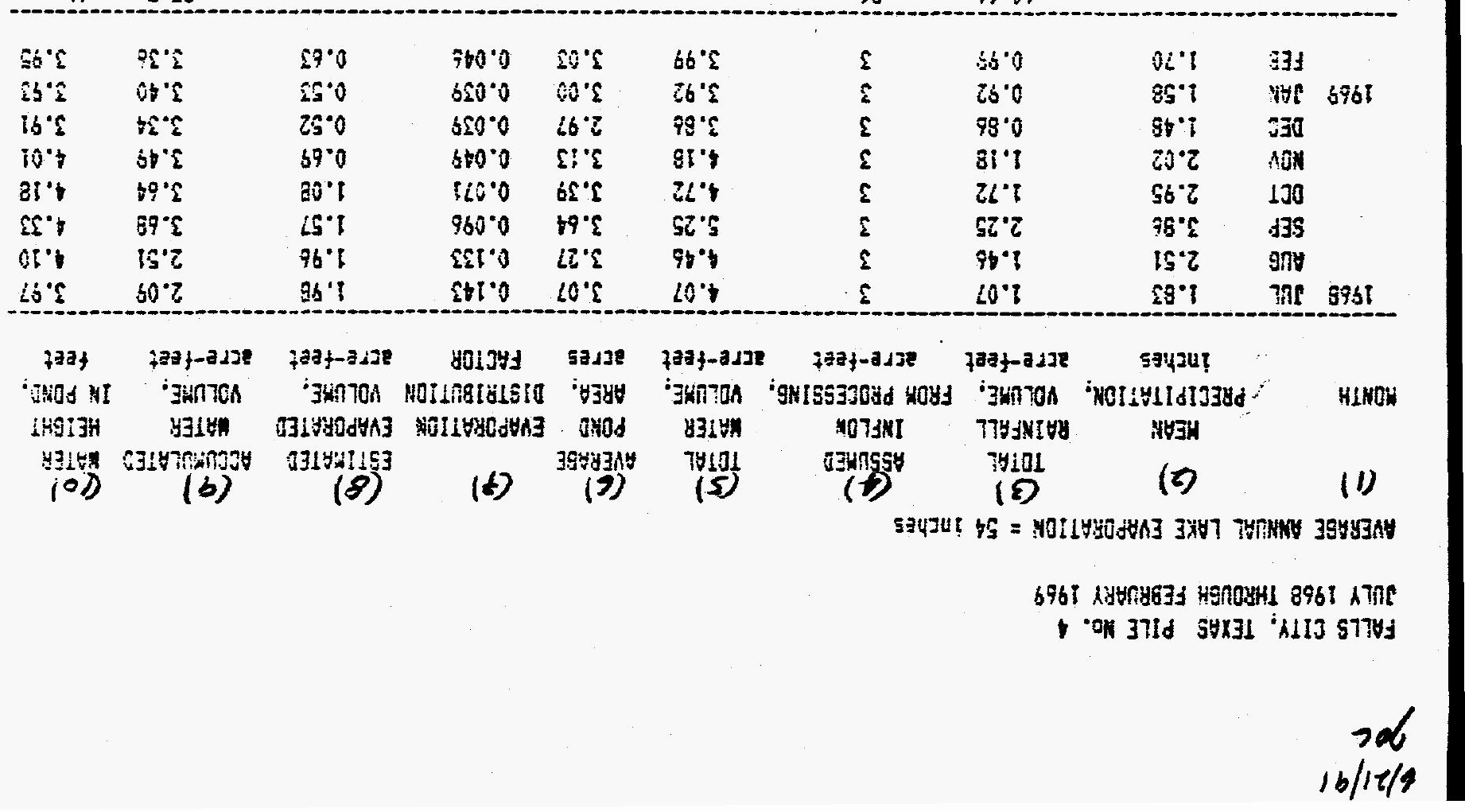


FAL:S CITY, TEXAS FILE NE. 5

RAREN 1969 THRQUGH FEBRUAAY 1970

AYERAGE AHNUA: LAKE EVAPORETIIN = 54 inETES

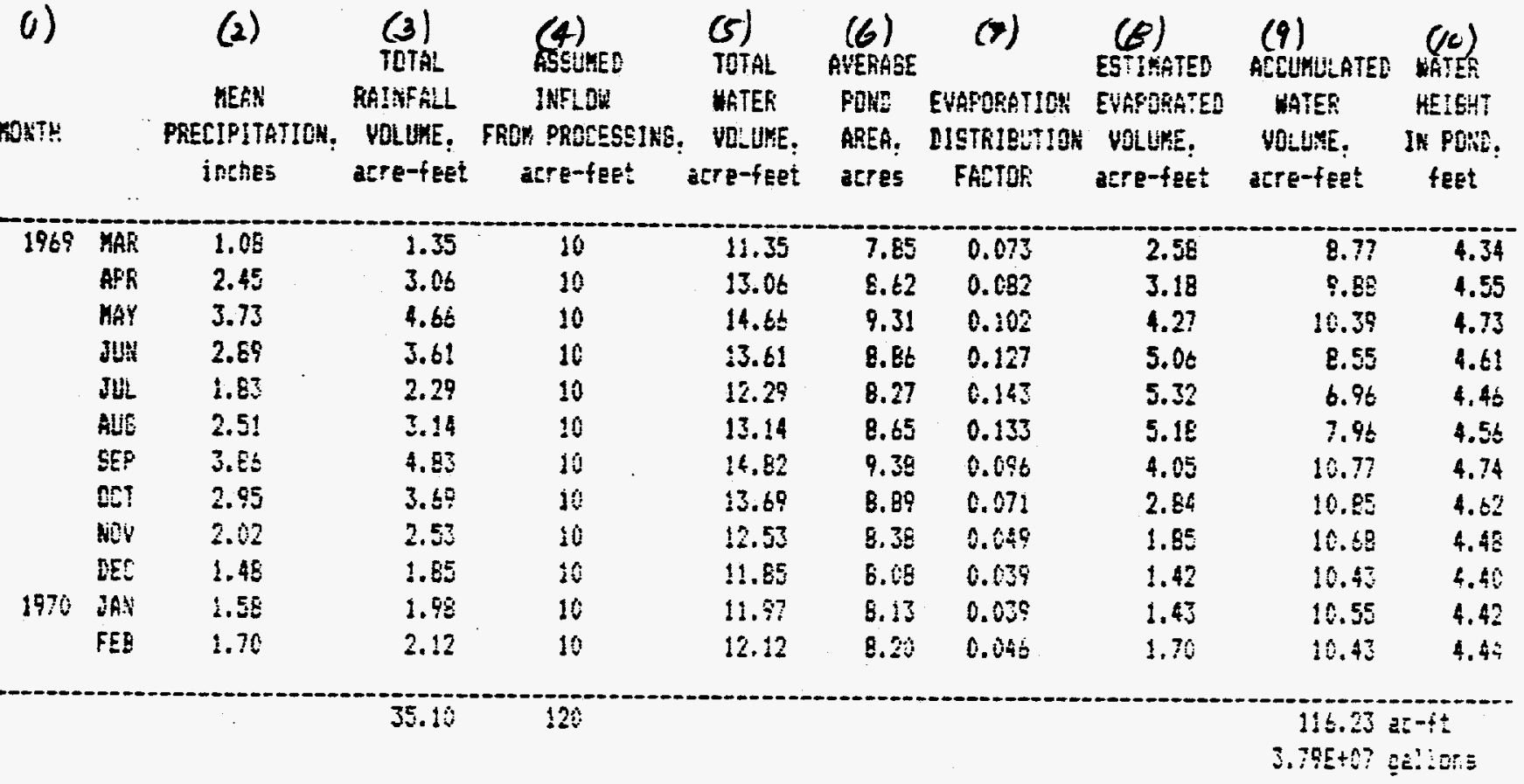


FALLS CITY. TEXSS PILE NO. 7

MAKCH 1970 THROUGH MAY 1973

AVERAGE AMHUEL LAKE EVAPOBATION $=54$ inches
(i)
(2)
(3)
(4)
(5) (6)
(7)
(e)
(9)
ESTIMATED ACCLULLATED WATE
MOETH
MEA RAINFALL INFLOK
WATER POND EVAPQAATION EVAPGRATED WATER HEIGHT

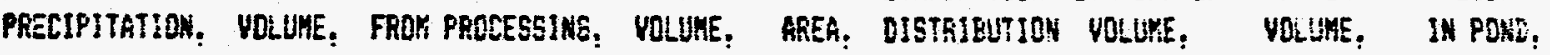 inches acre-feet acre-feet acre-feet acres FActis acre-feet acre-feet feet

\begin{tabular}{|c|c|c|c|c|c|c|c|c|c|c|}
\hline \multirow[t]{10}{*}{1970} & MAR & 1.09 & 3.60 & 10 & 13.60 & 12.28 & 0.073 & 4.03 & 9.57 & 3.32 \\
\hline & APR & 2.45 & 8.17 & 10 & 18.17 & 14.69 & 0.082 & 5.49 & 12.67 & 3.66 \\
\hline & MAY & 3.73 & 12.43 & 10 & 22.43 & 17.14 & 0.102 & 7.87 & 14.57 & 3.73 \\
\hline & Juk & 2.89 & 9.63 & 10 & 19.63 & 15.68 & 0.127 & 8.96 & 10.67 & 3.76 \\
\hline & JUL & 1.83 & 6.10 & 10 & 16.10 & 13.74 & 0.143 & 8.84 & 7.26 & 3.52 \\
\hline & A46 & 2.51 & 8.37 & 10 & 18.37 & 15.00 & 0.133 & 8.98 & 9.39 & 3.57 \\
\hline & SEF & 3.86 & 12.87 & 10 & 22.87 & 17.36 & 0.096 & $7.5 \hat{0}$ & 15.37 & 3.95 \\
\hline & get & 2.95 & $9.8 j$ & 10 & 19.83 & 15.79 & 0.071 & 5.04 & 14.79 & 3.77 \\
\hline & $\mathrm{MSO}$ & 2.02 & 6.73 & 10 & 16.73 & 14.89 & 0.048 & $3.1:$ & $13.6 ?$ & 3.5 \\
\hline & DES & 1.48 & 4.43 & 10 & 14.93 & 13.06 & 0.035 & 2.29 & 12.64 & 3.43 \\
\hline \multirow[t]{12}{*}{ :97! } & IAli & 1.59 & 5.27 & 10 & $: 5.27$ & 13.26 & 0.038 & 2.33 & 12.94 & 3.45 \\
\hline & $F E \bar{B}$ & 1.70 & 5.67 & 10 & $15.6 ?$ & 13.49 & 0.048 & 2.75 & 12.87 & 3.48 \\
\hline & AAE & 1.08 & 3.60 & $: 0$ & 13.6. & 12.28 & 0.073 & 4.03 & 9.57 & 3.32 \\
\hline & APR & 2.45 & 8.17 & 90 & 98.17 & 14.89 & 0.062 & 5.45 & $: 2.67$ & S.ts \\
\hline & hey & 3.73 & 12.43 & 10 & 22.45 & $17 . \therefore 4$ & 0.102 & $7.8 ?$ & 14.57 & 3.93 \\
\hline & Jigk & 2.99 & $\$ .63$ & $: 0$ & 19.63 & $15.6 E$ & 0.127 & 8.96 & 10.67 & $3.7 t$ \\
\hline & JwL & ¿.8Z & 6.10 & 10 & 26.50 & $: 3.74$ & 0.143 & 8.84 & 7.26 & 3.52 \\
\hline & A.5 & 2.51 & 5.37 & 10 & 18.37 & 15.60 & 0.153 & 8.98 & 9.39 & 3.67 \\
\hline & SEP & 3.56 & 12.87 & 10 & $22.8 ?$ & 17.56 & 0.096 & 7.50 & 45,37 & 3.75 \\
\hline & ECT & 2.95 & 9.83 & 10 & 14.83 & 15.79 & 0.075 & 5.04 & 14.79 & 3.77 \\
\hline & MEV & 2.02 & 6.73 & 10 & 16.73 & 14.09 & 0.349 & 3.11 & 13.67 & $3.5 t$ \\
\hline & DEE & 1.48 & 4.93 & 10 & 14.93 & $13.0 \mathrm{t}$ & 0.039 & 2.29 & $12.6 \%$ & $3.4 \pi$ \\
\hline \multirow[t]{12}{*}{1972} & JA! & 1.58 & 5.27 & 10 & 15.27 & 33.26 & 0.039 & 2.33 & 12.94 & 3.45 \\
\hline & FEE & 1.70 & 5.67 & 10 & 15.67 & 13.49 & $0.04 t$ & 2.73 & 12.87 & 3.43 \\
\hline & rifR & 1.08 & 3.60 & 10 & 13.60 & 12.25 & 0.073 & 4.03 & $\$ .57$ & 3.32 \\
\hline & $A F F$ & 2.45 & 8.17 & 10 & 18.17 & $14.8^{9}$ & 0.082 & 5.49 & 12.67 & 3.66 \\
\hline & MAY & 3.73 & $\$ 2.43$ & 10 & 22.43 & $\$ 7.14$ & 0.102 & 7.87 & 14.57 & 3.93 \\
\hline & JUN & 2.89 & 9.63 & 10 & 19.63 & 15.68 & 0.127 & 8.96 & 10.67 & $3.7 \mathrm{t}$ \\
\hline & vit: & 1.83 & 6.10 & 10 & 16.10 & 13.74 & 0.143 & B.84 & 7.25 & 3.52 \\
\hline & AUS & 2.51 & 6.37 & 10 & 16.37 & 15.00 & 0.133 & 8.98 & 9.39 & 3.67 \\
\hline & SEF & 3.86 & $12.8 ?$ & 10 & 22.87 & 17.36 & 0.096 & 7.50 & 15.37 & 3.95 \\
\hline & ECT & 2.95 & 9.83 & 10 & 19.83 & 15.79 & 0.071 & 5.04 & 14.79 & 3.77 \\
\hline & NOV & 2.02 & 6.73 & 10 & 16.73 & 14.09 & 0.049 & 3.11 & 13.63 & 3.56 \\
\hline & DEC & 1.48 & 4.93 & 10 & 14.93 & 13.06 & 0.039 & 2.29 & 12.64 & $3.4 j$ \\
\hline \multirow[t]{5}{*}{1573} & dâk & 1.58 & 5.27 & 10 & 15.27 & 13.26 & 0.039 & 2.33 & 12.94 & 3.45 \\
\hline & FEE & 1.70 & 5.67 & 10 & 15.67 & 13.19 & 0.046 & 2.79 & 12.87 & 3.48 \\
\hline & MAR & 1.09 & 3.60 & 10 & 13.60 & 12.29 & 0.073 & 4.03 & 9.57 & 3.32 \\
\hline & 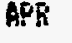 & 2.45 & B.17 & 10 & 18.17 & 14.89 & 0.082 & 5.49 & 12.67 & 3.66 \\
\hline & MAY & 3.73 & 12.43 & 10 & 22.43 & 17.14 & 0.102 & 7.87 & 14.57 & 3.92 \\
\hline
\end{tabular}


SUMraAY OF IMFILTRATIDU VULJHES

\begin{tabular}{|c|c|c|c|c|c|}
\hline \multirow[b]{2}{*}{ PILE } & \multirow{2}{*}{$\begin{array}{l}\text { TOTAL } \\
\text { SOSFEE } \\
\text { VOLLME: } \\
\text { ga!lons }\end{array}$} & \multirow[b]{2}{*}{$\begin{array}{l}\text { FEACTION } \\
\text { ERBK } \\
\text { RAINFALL }\end{array}$} & \multirow[b]{2}{*}{$\begin{array}{l}\text { FRACTIOH } \\
\text { FROY } \\
\text { PROCESSIHS }\end{array}$} & \multicolumn{2}{|c|}{$\begin{array}{l}\text { IIKTOTAL VOLUMES THATIH } \\
\text { THEAY HAUE INFULTKATEDIt }\end{array}$} \\
\hline & & & & $\begin{array}{l}\text { RAIMFALL: } \\
\text { gallons }\end{array}$ & $\begin{array}{l}\text { ORE PRCCESSING. } \\
\text { Qallons }\end{array}$ \\
\hline 1 & 4. $81 E+07$ & 0.55 & 0.45 & $2.65 E+07$ & $2.16 E+07$ \\
\hline 2 & $3.27 E+07$ & 0.63 & 0.37 & $2.06 E+07$ & $1.21 E+07$ \\
\hline 4 & 8. $31 E+06$ & 0.30 & 0.70 & $2.49 E+06$ & 5. $82 E+06$ \\
\hline 5 & $3.79 E+\hat{0} 7$ & 0.23 & 0.77 & $8.72 E+06$ & $2.92 E+07$ \\
\hline 7 & $1.55 E+\hat{w} E$ & 0.47 & 0.53 & $7.28 E+07$ & $8.22 E+07$ \\
\hline & $2.82 E+08$ & & & $1.31 E+05$ & $1.51 E+08$ \\
\hline
\end{tabular}


FALLS CITY. TEXAS MEATHER STATION

PERIOL OF RECORD AUE 1946 THROUGH KDV 1990

JAN FEB MAR APR MAY JUN JUL AUG SEF DET NOU DEC

ANMUAL

RAINFALL

\begin{tabular}{|c|c|c|c|c|c|c|c|c|c|c|c|c|c|}
\hline 2946 & & & & & & & & 10.25 & 7.05 & 8.15 & 2.80 & 2.10 & \\
\hline 1947 & 2.52 & 0.00 & 1.77 & 2.93 & 6.98 & & & 3.71 & 0.00 & & & & \\
\hline 1948 & & & & & & & & & 3.50 & 2.55 & 1.37 & & \\
\hline 1949 & 2.85 & 3.46 & 1.04 & 9.89 & 1.48 & 2.51 & 3.28 & 1.66 & 0.72 & 6.54 & 0.00 & 5.63 & 39.06 \\
\hline 1950 & 0.30 & 1.00 & 2.15 & 1.59 & 3.14 & 3.94 & 1.63 & 2.81 & 1.85 & 0.42 & 0.11 & 0.00 & 18.94 \\
\hline 1951 & 0.34 & 1.16 & 2.27 & 0.14 & 6.19 & 3.44 & 0.32 & 0.17 & 3.59 & 1.29 & 1.48 & 0.13 & 20.82 \\
\hline 1952 & 0.20 & 2.11 & 0.92 & 1.61 & 3.07 & 0.68 & 2.09 & 0.00 & 6.92 & 0.00 & 3.05 & 1.54 & 22.19 \\
\hline 1953 & 0.34 & 1.80 & 0.25 & 1.67 & 7.71 & 2.70 & 0.68 & 1.93 & 3.72 & 5.29 & 0.29 & 1.98 & 28.36 \\
\hline 1954 & 0.28 & 0.06 & 0.06 & 4.27 & 5.32 & 1.10 & 1.57 & 1.26 & 0.90 & 1.45 & 0.94 & 0.08 & 17.29 \\
\hline 1955 & 0.95 & 2.40 & 0.63 & 0.13 & 2.71 & 2.39 & 1.12 & 5.36 & 1.18 & 0.21 & 0.76 & 0.75 & 18.59 \\
\hline 1956 & 0.55 & 0.42 & 0.30 & 0.85 & 0.93 & 1.60 & 0.33 & 0.63 & 1.70 & 1.26 & 1.37 & 1.40 & 11.34 \\
\hline 1957 & 0.22 & 1.89 & 2.72 & 9.17 & 4.85 & 2.71 & 0.00 & 0.28 & 10.74 & 1.42 & 6.70 & 0.45 & 41.15 \\
\hline 1958 & 6.21 & 1.78 & 0.22 & 1.15 & 3.22 & 2.77 & 0.48 & 2.04 & 3.90 & 7.48 & 0.98 & 1.56 & 31.79 \\
\hline 1959 & 0.27 & 3.05 & 0.11 & 2.25 & 3.91 & 2.40 & 0.63 & 1.01 & 1.05 & 3.35 & 3.59 & 0.19 & 21.81 \\
\hline 1960 & 0.81 & 2.11 & 1.02 & 1.41 & 0.66 & 4.43 & 6.74 & 11.21 & 1.00 & 8.79 & 4.14 & 3.73 & 46.05 \\
\hline 2961 & 1.23 & 2.48 & 0.48 & 3.57 & 0.34 & 5.01 & 1.78 & 0.00 & 2.27 & 5.73 & 5.57 & 0.50 & 28.96 \\
\hline 1962 & $0.5 !$ & 0.65 & 0.94 & 4.27 & 1.46 & 6.01 & 0.00 & 0.00 & 4.13 & 0.82 & 1.98 & 3.41 & 24.18 \\
\hline 1963 & 0.28 & 3.00 & 0.09 & 0.75 & 2.86 & 2.72 & 2.05 & 0.00 & 2.20 & 2.16 & 3.73 & 2.53 & 22.37 \\
\hline 1964 & 2.01 & 2.05 & 1.72 & 0.99 & 1.86 & 1.44 & 0.00 & 5.77 & 1.96 & 1.44 & 0.73 & 1.10 & 21.07 \\
\hline 1965 & 1.97 & 5.88 & 0.95 & 1.18 & 7.80 & 1.04 & 0.18 & 0.87 & 2.26 & 2.85 & 1.00 & 3.36 & 29.34 \\
\hline 1966 & 2.02 & 1.93 & 0.85 & 4.09 & 3.50 & 2.30 & 2.16 & 1.68 & 2.51 & 0.53 & 0.00 & 0.45 & 22.02 \\
\hline 1967 & 0.63 & 0.88 & 1.52 & 1.50 & 1.24 & 0.00 & 3.00 & 6.05 & 15.23 & 3.67 & 3.25 & 0.96 & 37.93 \\
\hline 1968 & 6.47 & 2.02 & 0.91 & 1.38 & 4.66 & 2.39 & 2.69 & 2.46 & 12.56 & 1.51 & 2.92 & 1.96 & 41.93 \\
\hline 1969 & 1.52 & 1.03 & 1.85 & - & 7.15 & 1.91 & 0.00 & 2.95 & 0.81 & 4.92 & 2.66 & 3.45 & 28.25 \\
\hline 1970 & 2.31 & 2.52 & 3.69 & 1.64 & 6.24 & 1.27 & 1.27 & 2.80 & 2.15 & 0.36 & 0.00 & 0.31 & 23.96 \\
\hline 1971 & 0.00 & 1.10 & 0.00 & 1.50 & 0.06 & 4.74 & 0.00 & 3.85 & 7.16 & 3.05 & 1.16 & 2.01 & 24.93 \\
\hline 1972 & 1.48 & 0.39 & 1.06 & 0.57 & 5.84 & 2.89 & 6.25 & 4.11 & 4.45 & 0.57 & 1.94 & 0.34 & 29.89 \\
\hline 1973 & 2.71 & 4.07 & 1.13 & 3.66 & 1.09 & 12.85 & 0.37 & 2.11 & 10.03 & 4.95 & 0.36 & 0.45 & 43.78 \\
\hline 1974 & 2.40 & 0.36 & 0.88 & 0.68 & 7.23 & 0.77 & 1.22 & 6.26 & 3.63 & 0.93 & 2.39 & 1.05 & 28.00 \\
\hline 1575 & - & 1.32 & 0.00 & 1.40 & $8.6 ?$ & 6.21 & 1.06 & 1.75 & 1.27 & 2.29 & 0.20 & 0.52 & 24.69 \\
\hline 1976 & 0.42 & 0.00 & 0.72 & 5.24 & 4.17 & 0.12 & 4.19 & 0.00 & 6.12 & 8.27 & 3.56 & 2.49 & 35.30 \\
\hline 1977 & 2.36 & 1.18 & 0.60 & 8.11 & 3.67 & 1.37 & 0.00 & 0.00 & $0.9 B$ & 0.87 & 2.75 & 0.21 & 22.10 \\
\hline 1978 & 1.02 & 1.61 & 0.78 & 1.73 & 1.40 & 3.12 & 3.37 & 1.82 & 8.78 & 0.98 & 2.78 & 2.03 & 29.42 \\
\hline 1979 & 3.45 & 1.30 & 0.77 & 4.86 & 3.95 & 4.03 & 4.52 & 2.98 & 1.67 & 0.00 & 0.77 & 1.35 & 29.65 \\
\hline 1980 & 0.69 & 0.63 & 0.37 & 0.33 & 8.20 & 0.00 & 1.56 & 7.11 & 8.32 & 1.06 & 3.32 & 0.97 & $32.5 t$ \\
\hline 1981 & 1.67 & 1.19 & 1.14 & 2.35 & $7.3 !$ & 4.94 & 0.12 & 2.85 & 1.85 & 4.00 & 0.60 & 0.44 & 22.11 \\
\hline 1982 & 0.12 & 6.12 & 0.29 & 1.05 & 4.64 & 3.04 & 0.21 & 1.92 & $2.4 B$ & 6.65 & 2.24 & 0.85 & 29.61 \\
\hline 1983 & 1.43 & 1.80 & 2.77 & 0.00 & 2.68 & 2.53 & 4.22 & 2.71 & 5.47 & 1.12 & 1.74 & 0.23 & 26.70 \\
\hline 1984 & 3.35 & 0.66 & 0.44 & 0.50 & 0.68 & 0.22 & 0.00 & 0.00 & 1.85 & 7.13 & 0.77 & 1.25 & 16.85 \\
\hline 1985 & 2.68 & 1.44 & 2.01 & 5.79 & 1.41 & 1.04 & 1.73 & 0.00 & 5.54 & 4.18 & 6.21 & 0.36 & 32.39 \\
\hline 1986 & 1.51 & 0.54 & 0.28 & 0.46 & 4.33 & 3.43 & 0.00 & 0.20 & - & 3.77 & 2.55 & 5.53 & 22.60 \\
\hline 1987 & 1.27 & 4.30 & 0.88 & 0.00 & 3.23 & 11.72 & 1.53 & 4.00 & 0.76 & 0.30 & 3.15 & 3.01 & 34.15 \\
\hline 1988 & 0.45 & 0.07 & 0.42 & 1.84 & 2.93 & 2.49 & 2.38 & 0.00 & 3.80 & 0.85 & 0.00 & 0.91 & 16.14 \\
\hline 1989 & 3.51 & 0.39 & 1.76 & 3.32 & 0.81 & 1.31 & 1.05 & 1.84 & 0.35 & 4.42 & 2.19 & 0.18 & 21.43 \\
\hline 1990 & 1.06 & 0.91 & 4.30 & 2.76 & 0.92 & 0.00 & 10.92 & 2.12 & 1.12 & 2.05 & 0.97 & - & 27.13 \\
\hline & 1.58 & 1.70 & 1.08 & 2.45 & 3.73 & 2.89 & 1.83 & 2.51 & 3.86 & 2.95 & 2.02 & 1.48 & \\
\hline
\end{tabular}

